NBSIR 83-2746

\title{
Strategies for Energy Conservation for A Large Office Building
}

U.S. DEPARTMENT OF COMMERCE

National Bureau of Standards

National Engineering Laboratory

Center for Building Technology

Building Equipment Division

Washington, DC 20234

July 1983

Prepared for

- fice of Building Energy Research and Development

fice of Conservation and Renewable Energy

100 S. Department of Energy

. U56 ashington, DC

$83-2746$

1983

C. 2 

$\ldots$

\section{STRATEGIES FOR ENERGY CONSERVATION FOR A LARGE OFFICE BUILDING}

James Y. Kao

U.S. DEPARTMENT OF COMMERCE

National Bureau of Standards

National Engineering Laboratory

Center for Building Technology

Building Equipment Division

Washington, DC 20234

July 1983

Prepared for

Office of Building Energy Research and Development

Office of Conservation and Renewable Energy

U.S. Department of Energy

Washington, DC

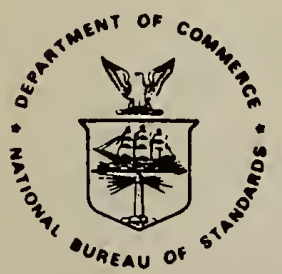



A comparative analysis is made of the thermal performance of selected HVAC systems and control strategies commonly employed in large office buildings. The comparisons are made for six geographical locations representing wide climatic variations within the continental United States.

Hour-by-hour simulations with the BLAST computer program are used to obtain the yearly heating, cooling, and fan energy consumption of a twelve-story large office building. The HVAC systems simulated are constant volume reheat, variable air volume, dual-duct, and fan-coil systems. The control strategies tested are dry-bulb temperature economy cycles, enthalpy economy cycle, supplyair-temperature resetting, and the combinations of these strategies. The results of these simulations are presented and discussed. Substantial energy consumption differences are shown to exist.

Key words: building control strategies; building energy conservation; building thermal performance; HVAC systems 


\section{PREFACE}

This report is one of a series documenting NBS research and analysis efforts in developing energy and cost data to support the Department of Energy/National Bureau of Standards Building Energy Conservation Criteria Program. The work reported in this document was performed under the Energy Analys is of Control Strategies project, a part of the controls program element managed by Building Systems Division, Office of Building Energy Research and Development, U.S. Department of Energy. The NBS effort was supported by DoE/NBS Task Order A008BCS under Interagency Agreement No. EA77A 01-6010. 
Abstract ...............................................

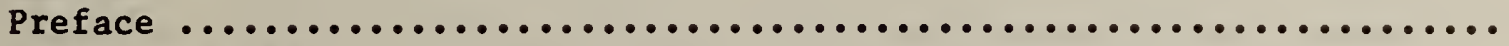

List of Tables ...........................................

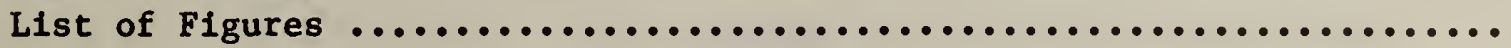

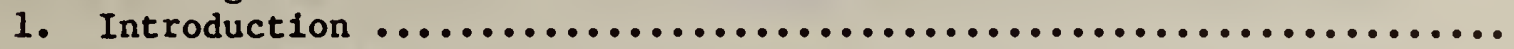

2. Energy Simulation ................................... 2.1 Bullding Model ..................................

2.2 HVAC System Simulation and Control Strategies .............

3. Results and Discussion .................................

3.1 Energy Consumption Results .........................

3.2 Comparison of Strategies ...........................

4. Summary and Conclusions

References 
$\underline{\text { Page }}$

Table 1. Annual Energy Consumption - Lake Charles, LA ........... 18

Table 2. Annual Energy Consumption - Madison, wI ............... 19

Table 3. Annual Energy Consumption - Nashville, TN ............. 20

Table 4. Annual Energy Consumption - Santa Maria, CA ............ 21

Table 5. Annual Energy Consumption - Seattle, WA . .............. 22

Table 6. Annual Energy Consumption - Washington, DC ............ 23

Table 7. Comparative Annual Energy Consumption - Lake Charles, LA ... 24

Table 8. Comparative Annual Energy Consumption - Madison, WI ....... 25

Table 9. Comparative Annual Energy Consumption - Santa Maria, CA .... 26

Table 10. Comparative Annual Energy Consumption - Nashville, TN ..... 27

Table 11. Comparative Annual Energy Consumption - Seattle, WA ...... 28

Table 12. Comparative Annual Energy Consumption - Washington, DC ..... 29 


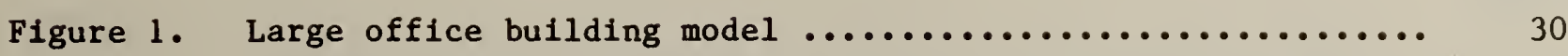

Figure 2. Internal load profiles ........................ 31

Figure 3. Cooling energy consumption of case 1 -- base reheat ....... 32

Figure 4. Cooling energy consumption of case 2 -- base reheat with temperature economy cycle .........................

Figure 5. Cooling energy consumption of case 3 -- base reheat with return air economy cycle ..........................

Figure 6. Cooling energy consumption of case 4 -- base reheat with enthalpy economy cycle ...........................

Figure 7. Cooling energy consumption of case 5 -- base reheat with supply air reset by outside air ......................

Figure 8. Cooling energy consumption of case 6 -- base reheat with supply air reset by zone load demand ...................

Figure 9. Cooling energy consumption of case 7 -- base reheat with enthalpy economy cycle and supply air reset by zone load demand

Figure 10. Cooling energy consumption of case 8 -- base VAV with enthalpy economy cycle ...........................

Figure 11. Cooling energy consumption of case $9--$ base VAV with

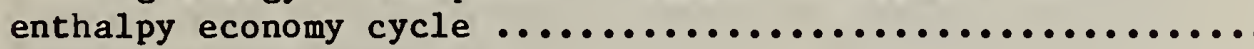

Figure 12. Cooling energy consumption of case 10 -- base $\mathrm{RH}$ for interior zones, base DD for perimeter zones ...............

Figure 13. Cooling energy consumption of case $11-$ base VAV for interior zones, base DD for perimeter zones .............

Figure 14. Cooling energy consumption of case 12 -- base RH with enthalpy economy cycle for interior zones, base DD with enthalpy economy cycle for perimeter zones ...............

Figure 15. Cooling energy consumption of case $13--$ base VAV with enthalpy economy cycle for interior zones, base DD with enthalpy economy cycle for perimeter zones 
Figure 16. Cooling energy consumption of case 14 -- base RH with enthalpy economy cycle for interior zones, base DD with enthalpy economy cycle and hot deck reset by outside air

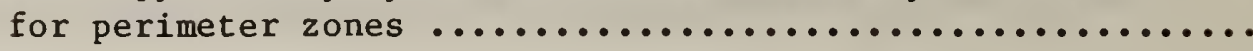

Figure 17. Cooling energy consumption of case 15 -- base VAV with enthalpy economy cycle for interior zones, base DD with enthalpy economy cycle and hot deck reset by outside air for perimeter zones ..............................

Figure 18. Cooling energy consumption of case 16 -- base RH with enthalpy economy cycle and supply air reset by zone demand for interior zones, base DD with enthalpy economy cycle and hot-cold decks reset by zone demands for perimeter zones

Figure 19. Cooling energy consumption of case 17 -- base VAV with enthalpy economy cycle for interior zones, base DD with enthalpy economy cycle and hot-cold decks reset by zone

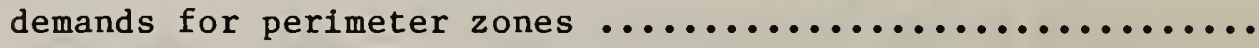

Figure 20. Cooling energy consumption of case 18 -- base RH with enthalpy economy cycle and supply air reset by zone demand for interior zones, base VAV with enthalpy economy cycle

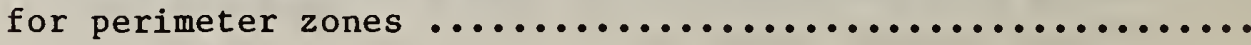

Figure 21. Cooling energy consumption of case $19--$ base RH with enthalpy economy cycle and supply air reset by zone demand for interior zones, fan-coil for perimeter zones

Figure 22. Cooling energy consumption of case $20--$ base VAV with enthalpy economy cycle for interior zones, fan-coil for perimeter zones ................................

Figure 23. Cooling energy consumption of cases 1 through 7 -- all RH

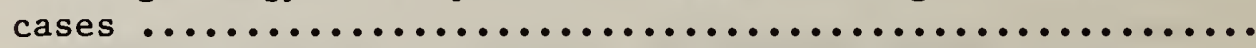

Figure 24. Cooling energy consumption of cases 8 and 9 -- all VAV cases

Figure 25. Cooling energy consumption of cases $11,13,15$, and 17 -VAV for interior zones, DD for perimeter zones ...........

Figure 26. Cooling energy consumption of cases $7,9,17$, and $20--$

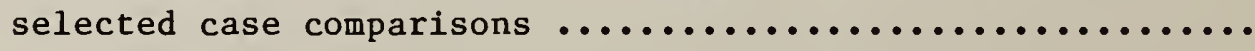

Figure 27. Heating energy consumption of case 1 -- base reheat ....... 
Figure 28. Heating energy consumption of case 2 -- base reheat with temperature economy cycle ..........................

Figure 29. Heating energy consumption of case 3 -- base reheat with return air economy cycle .........................

Figure 30. Heating energy consumption of case 4 -- base reheat with enthalpy economy cycle ..........................

Figure 31. Heating energy consumption of case 5 -- base reheat with supply air reset by outside air......................

Figure 32. Heating energy consumption of case 6 -- base reheat with supply air reset by zone load demand ...................

Figure 33. Heating energy consumption of case 7 -- base reheat with enthalpy economy cycle and supply air reset by zone load demand ........................................

Figure 34. Heating energy consumption of case 8 -- base VAV with enthalpy economy cycle ...........................

Figure 35. Heating energy consumption of case $9--$ base VAV with enthalpy economy cycle $\ldots \ldots \ldots \ldots \ldots \ldots \ldots \ldots \ldots \ldots \ldots \ldots \ldots \ldots$

Figure 36. Heating energy consumption of case 10 -- base RH for interior zones, base DD for perimeter zones .............

Figure 37. Heating energy consumption of case 11 -- base VAV for interior zones, base DD for perimeter zones ..............

Figure 38. Heating energy consumption of case 12 -- base RH with enthalpy economy cycle for interior zones, base DD with enthalpy economy cycle for perimeter zones ...............

Figure 39. Heating energy consumption of case 13 -- base VAV with enthalpy economy cycle for interior zones, base DD with enthalpy economy cycle for perimeter zones ..............

Figure 40. Heating energy consumption of case $14--$ base RH with enthalpy economy cycle for interior zones, base DD with enthalpy economy cycle and hot deck reset by outside air for perimeter zones 
Figure 41. Heating energy consumption of case 15 -- base VAV with enthalpy economy cycle for interior zones, base DD with enthalpy economy cycle and hot deck reset by outside air

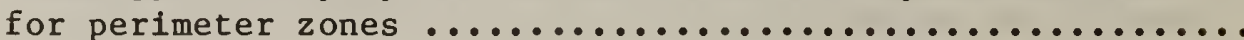

Figure 42. Heating energy consumption of case 16 -- base RH with enthalpy economy cycle and supply air reset by zone demand for interior zones, base DD with enthalpy economy cycle and hot-cold decks reset by zone demands for perimeter

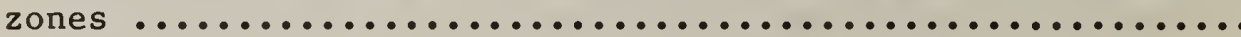

Figure 43. Heating energy consumption of case 17 -- base VAV with enthalpy economy cycle for interior zones, base DD with enthalpy economy cycle and hot-cold decks reset by zone

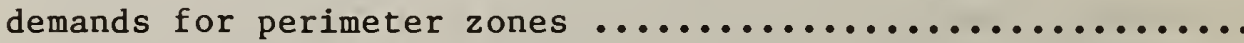

Figure 44. Heating energy consumption of case 18 -- base RH with enthalpy economy cycle and supply air reset by zone demand for interior zones, base VAV with enthalpy economy cycle for perimeter zones

Figure 45. Heating energy consumption of case $19-$ base RH with enthalpy economy cycle and supply air reset by zone demand for interior zones, fan-coil for perimeter zones .........

Figure 46. Heating energy consumption of case 20 -- base VAV with enthalpy economy cycle for interior zones, fan-coil for

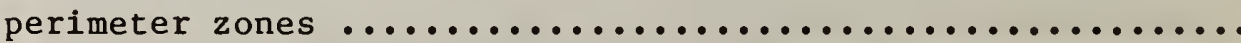

Figure 47. Heating energy consumption of cases 1 through 7 -- all RH

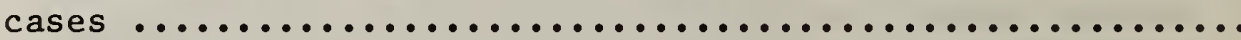

Figure 48. Heating energy consumption of cases 8 and 9 -- all VAV

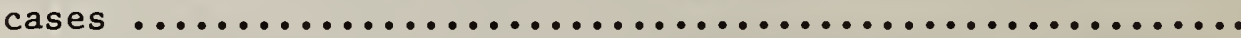

Figure 49. Heating energy consumption of cases $11,13,15$, and 17 -VAV for interior zones, DD for perimeter zones ...........

Figure 50. Heating energy consumption of cases $7,9,17$, and 20 -selected case comparisons 


\section{INTRODUCTION}

This report is the third in a series of reports by researchers at the National Bureau of Standards which compare the energy consumption of alternative heating, ventilating, and air conditioning (HVAC) systems and control strategies for commercial buildings. The purpose of this report, along with the two previous reports which studied a small office building [1]* and a large retail store [2], was to generate comparative energy use data for various building types in different geographical locations in the United States. These studies were intended to derive general guidelines limited to HVAC control strategy selections for building operators and designers. The present study which specifically deals with large office buildings uses a large multi-story building as a model. The energy saving potential for large office buildings as a group is substantial, since over 15 percent of the buildings larger than 50,000 $\mathrm{ft}^{2}\left(4,645 \mathrm{~m}^{2}\right)$ in floor area are office buildings [3]. The HVAC systems and control strategies employed in this study were those most commonly used for this type of building. The results and conclusions of this study should aid prospective users in making preliminary decisions about strategies for air-handling system control in both new and renovative work.

The energy program used in this study was the Building Loads Analysis and System Thermodynamics Program (BLAST, Version 2.0) [4]. The cities used for the energy simulations in the present series of reports [including 1, and 2] were Lake Charles, Louisiana; Madison, Wisconsin; Nashville, Tennessee; Santa Maria, California; Seattle, Washington; and Washington, D.C. These cities range from approximately 1500 to 8000 heating degree days $\left(65^{\circ} \mathrm{F}\right.$ base) and from 100 to 3000 cooling degree days $\left(65^{\circ} \mathrm{F}\right.$ base), and represent a wide variety of climatic conditions in the United States.

The energy consumption results of this study were limited to the energy consumed by the air-handling systems. For the readers who are interested in comparing the dollar cost of different systems and control strategies, it is necesary to modify the present data with energy transmission losses, plant efficiencies, and energy costs.

Since the BLAST-2 program is an hourly energy program, the energy effect caused by the dynamics of the control component interactions may not be included in the energy consumption results. The size of this effect, which may be significant, was not investigated in this study.

* See references at end of text. 


\section{ENERGY SIMULATION}

\subsection{BUILDING MODEL AND WEATHER DATA}

The building being modeled was a twelve-story general office building, 200 feet $(61.0 \mathrm{~m})$ long in the east-west direction and $100 \mathrm{feet}(30.5 \mathrm{~m})$ wide in the north-south direction. The building dimensions and pertinent construction data, as well as the thermal zone arrangements, are shown in figure 1 . The building was of light construction and was well insulated. The floor-to-floor height was 13 feet $(4.0 \mathrm{~m})$. The fenestration area was approximately 42 percent of the gross wall area on all four sides of the building. The daily occupancy, lighting, and equipment profiles and loadings are shown in figure 2. It was assumed that 30 percent of the lighting load was absorbed by the return air directly, without imposing a cooling load on the space. During the system operational hours, the building was assumed to be pressurized and have no infiltration. During system off hours, when no outside air was admitted into the air-handling systems, the infiltration was assumed to be approximately 0.2 air changes per hour in the perimeter zones. This infiltration rate agreed closely with the measured infiltration rates of a large commercial building of similar exterior wall construction [5]. The systems admitted ventilation air at 10 percent of the supply air. This ventilation rate equaled no less than $8 \mathrm{cfm}\left(3.78 \times 10^{-3} \mathrm{~m}^{3} / \mathrm{s}\right)$ per person.

The building was zoned by interior/exterior spaces and exposures. Therefore, every floor had four exterior thermal zones and one interior thermal zone. Each exterior zone which was modeled had a floor area of $20 \mathrm{ft} \times 20 \mathrm{ft}$ $(6.1 \mathrm{~m} \times 6.1 \mathrm{~m})$ while each interior zone had a floor area of $2000 \mathrm{ft}^{2}$ $\left(185.8 \mathrm{~m}^{2}\right)$. The modeled zone data were multiplied by the appropriate numbers to obtain the total air-handling system energy consumption.

The interior area of a typical floor space was about 43 percent of the total net floor area of that space. In order to reduce the computation cost, only the four exterior zones of a typical floor space and the interior zones of the top floor and typical floor were simulated. Therefore, six zone simulations were performed for each system/control strategy pair instead of the actual fifteen zone simulations (bottom, typical, and top floors) possible. The error introduced by this simplification, in terms of total supply air quantities, was calculated to be about 0.6 percent for Santa Maria and well below 0.5 percent for the other five cities. The average supply air quantities ranged between $0.84 \mathrm{cfm}$ per $\mathrm{ft}^{2}\left(3.96 \times 10^{-4} \mathrm{~m}^{3} / \mathrm{s}\right.$ per $\left.\mathrm{m}^{2}\right)$ of net floor area for Santa Maria to $1.04 \mathrm{cfm}$ per $\mathrm{ft}^{2}\left(4.91 \times 10^{-4} \mathrm{~m}^{3} / \mathrm{s}\right.$ per $\left.\mathrm{m}^{2}\right)$ of net floor area for Nashville.

The weather data used for the simulations were from the Typical Meteorological Year (TMY) climatic tapes [6].

\subsection{HVAC SYSTEM SIMULATION AND CONTROL STRATEGIES}

Four basic types of HVAC systems commonly used for high-rise office buildings were simulated in this study. They were constant volume terminal reheat, variable air volume, dual-duct, and fan-coil systems. All four systems were 
modeled for the perimeter zones while only the terminal reheat and variable air volume systems were used for the interior zones. A dual-duct system was not modeled for the interior system because of the relatively smaller load variations typical of the interior zones. The perimeter and interior zones were simulated separately. The energy consumptions of the four different perimeter systems were combined with those of the two interior zones to give the total building consumptions of different perimeter-interior combinations.

The capacities of the different air-handling systems were sized to keep the space temperatures between $68^{\circ} \mathrm{F}\left(20.0^{\circ} \mathrm{C}\right)$ and $78^{\circ} \mathrm{F}\left(25.6^{\circ} \mathrm{C}\right)$ during office hours. ASHRAE [7] 97.5 percent design dry-bulb temperature and 2.5 percent design dry-bulb/mean coincident wet-bulb temperature were used in zone load calculations. However, the yearly simulation runs indicated that the $78^{\circ} \mathrm{F}\left(25.6^{\circ} \mathrm{C}\right)$ upper space temperature was exceeded by more than $1^{\circ} \mathrm{F}\left(0.6^{\circ} \mathrm{C}\right)$ during high load hours for some cities. The night and weekend heating setback temperature was $52^{\circ} \mathrm{F}\left(11.1^{\circ} \mathrm{C}\right)$. The air handling system fans ran continously during office hours, from $8 \mathrm{a} . \mathrm{m}$. to $8 \mathrm{p} . \mathrm{m}$, and ran intermittently during setback hours. It was assumed that chilled water was available year-round during office hours and that the throttling range $l^{1}$ of the cooling coil controller was $3^{\circ} \mathrm{F}\left(1.7^{\circ} \mathrm{C}\right)$.

The control strategies tested in this study included the use of various outside air economy cycles, the resetting of cold and hot duct temperatures by outside air temperature or by zone load demands, and combinations of these strategies. Details of these strategies are given in the following paragraphs.

\section{A. Case 1 -- Base Reheat (RH) Systems for Whole Building}

Constant volume terminal reheat systems were simulated for both perimeter and interior zones. The supply-air temperature was $59^{\circ} \mathrm{F}\left(15.0^{\circ} \mathrm{C}\right)$ which included the fan heat gain. Ventilation air equivalent to 10 percent of supply air was introduced to the systems during all office hours. This amount of outside air is defined as the minimum outside air in this paper. The supply air fan and return air fan pressures were assumed to be 3 in. of water $\left(7.5 \times 10^{2} \mathrm{~Pa}\right)$ and $0.5 \mathrm{in}$. of water $\left(1.2 \times 10^{2} \mathrm{~Pa}\right)$, respectively.

B. Case 2 -- Reheat (RH) Systems with Temperature Economy Cycle

A temperature economy cycle was added to case 1 . The mixed-air temperature of the return and outside-air streams was maintained by modulating the dampers to satisfy the supply-air sensor setting. When the outside-air temperatures rose above the setting of this sensor, the outside-air damper was closed to its minimum outside air position and the building cooling was accomplished entirely by the chilled water.

1 Throttling range can be defined as the change required, in a proportional control system, in a controlled variable (such as air temperature) to move the controlled device (such as a coil valve) from one of its extreme limits of travel to the other (such as from fully open to fully closed). 
C. Case 3 -- Reheat (RH) Systems with Return Air Economy Cycle

This strategy was similar to that of case 2 except that the return-air temperature sensor was compared with the outside-air temperature. Whenever the outside-air temperature was below the return-air temperature, 100 percent outside air was admitted to offset part of the building cooling load. When the outside temperature was below the supply-air temperature setting, the amount of outside air and return air was mixed to satisfy the supply-air setting.

D. Case 4 -- Reheat (RH) Systems with Enthalpy Economy Cycle

When the enthalpy of the outside air was lower than that of the return air, the full amount of outside air was admitted to the systems, providing the temperature of the mixed air was not below the temperature setting of the supply air. Otherwise, only the minimum amount of outside air was admitted. This was accomplished by having enthalpy sensors in the return and outside air streams.

E. Case 5 -- Reheat (RH) Systems with Supply-Air Temperature Reset by Outside Air Temperature

The supply-air temperature of the perimeter system was changed from $59^{\circ} \mathrm{F}$ $\left(15.0^{\circ} \mathrm{C}\right)$ to $63^{\circ} \mathrm{F}\left(17.2^{\circ} \mathrm{C}\right)$ inversely with the outside air temperature, following a straight line relationship, from $90^{\circ} \mathrm{F}\left(32.2^{\circ} \mathrm{C}\right)$ to $70^{\circ} \mathrm{F}\left(21.1^{\circ} \mathrm{C}\right)$. Although this reset schedule was used for all 6 cities to demonstrate the benefit of resetting the supply air, it should not be construed as a recommended schedule. Except for the perimeter system resetting, this case is the same as case 1 .

F. Case 6 -- Reheat (RH) System with Supply Air Temperature Reset by Zone Load Demand

Instead of using an outside-air-temperature sensor to control the supply-air temperature, as described in case 5, multiple zone temperature sensors were simulated. These reset the supply air temperature to satisfy the peak demand zone during system operating hours. No supply-air temperature limit was specified in the input data. This strategy was applied to both perimeter and interior systems.

G. Case 7 -- Reheat (RH) System with Combined Strategies

This case combined the best economy cycle strategy with the best supply-air resetting strategy described above. In other words, both the enthalpy economy cycle and resetting supply-air temperature by zone load demand were applied to the entire building.

H. Case 8 -- Base Variable Air Volume (VAV) System

Variable air volume systems were used for both perimeter and interior zones. The minimum supply-air quantities of the VAV thermal units were set at 20 
percent of the supply air. The air-handling systems admitted the minimum outside air percentage at all times. Since the building had large interior spaces and the internal load variations were relatively small, the toilet exhaust and building pressurization could be maintained even at low load periods. The supply-air fan pressure was changed from 3 in. of water $\left(7.5 \times 10^{2} \mathrm{~Pa}\right)$ to $3.5 \mathrm{in}$. of water $\left(8.7 \times 10^{2} \mathrm{~Pa}\right)$ in the simulation to account for the added terminal unit pressure requirement. The supply-air temperature setting was $59^{\circ} \mathrm{F}\left(15.0^{\circ} \mathrm{C}\right)$, the same as for the reheat systems. The perimeter system had reheat coils in the terminal units, while the interior system had only the air volume controls.

I. Case 9 -- Variable Air Volume (VAV) System with Enthalpy Economy Cycle An enthalpy economy cycle was added to the VAV system from case 8.

J. Case 10 -- Base Reheat (RH) System for Interior Zones and Base Dual-Duct (DD) System for Perimeter Zones

A dual-duct system was used for the perimeter zones for this case and the following 7 cases (cases 10 through 17 ). The dual-duct system had preheat coils in the mixed-air stream with the main heating and cooling coils located in the hot and cold ducts. Case 10 combined the dual-duct system with a reheat system for the interior zones. Both systems used the minimum outside air percentage at all times and there was no resetting of any temperature controller. The cold air temperature was set at $59^{\circ} \mathrm{F}$ $\left(15.0^{\circ} \mathrm{C}\right)$ and the hot air temperature was set at $140^{\circ} \mathrm{F}\left(60.0^{\circ} \mathrm{C}\right)$ year-round. The supply and return fan air flow rates were the same as those of the reheat systems. The supply-air fan pressure was also $3.5 \mathrm{in}$. of water $\left(8.7 \times 10^{2} \mathrm{~Pa}\right)$ as in the VAV cases because of the pressure requirement of the mixing boxes. The cooling and heating coil capacities were not changed from those of the reheat systems. The energy losses from mixing damper leakage were not considered in any cases.

K. Case 11 -- Base Variable Air Volume (VAV) System for Interior Zones and Base Dual-Duct (DD) System for Perimeter Zones

In this case, the interior system was the same as the interior system of case 8 and the perimeter system was the same as in case 10. Again, only minimum outside air was used during office hours.

L. Case 12 -- Reheat (RH) System for Interior Zones and Dual-Duct (DD) System for Perimeter Zones, Enthalpy Economy Cycle

In this case, an enthalpy economy cycle was added to case 10.

M. Case 13 -- Variable Air Volume (VAV) System for Interior Zones and DualDuct (DD) System for Perimeter Zones, Enthalpy Economy Cycle

In this case, an enthalpy economy cycle was added to case 11. 
N. Case 14 -- Reheat (RH) System for Interior Zones and Dual-Duct (DD) System for Perimeter Zones, Enthalpy Economy Cycle, Resetting Hot Deck Temperature by Outside Air Temperature for Dual-Duct System

This case is the same as case 12 except that the hot-air duct temperature of the dual-duct system was reset inversely according to the outside air temperature. The hot air temperature was $140^{\circ} \mathrm{F}\left(60.0^{\circ} \mathrm{C}\right)$ when the outside air was $0^{\circ} \mathrm{F}$ or below $\left(-17.8^{\circ} \mathrm{C}\right)$. The hot air temperature was $70^{\circ} \mathrm{F}\left(21.1^{\circ} \mathrm{C}\right)$ when the outside was also $70^{\circ} \mathrm{F}\left(21.1^{\circ} \mathrm{C}\right)$ or above.

0. Case 15 -- Variable Air Volume (VAV) System for Interior Zones and Dua1Duct (DD) System for Perimeter Zones, Enthalpy Economy Cycle, Resetting Hot Deck Temperature by Outside Air Temperature for Dual-Duct System

In this case, the resetting of hot air temperature was applied to the dualduct system of case 13 . The reset schedule was the same as that of case 14 .

P. Case 16 -- Reheat (RH) System for Interior Zones and Dual-Duct (DD) System for Perimeter Zones, Enthalpy Economy Cycle, Resetting Both Hot and Cold Decks

This case is similar to case 14 except that both the hot and cold air temperatures were reset by sensors in the highest heating and cooling demand zones, respectively. In doing so, the dual-duct mixing loss was minimized. The reset temperature was also set between specific limits. Hot air temperature was limited to between $70^{\circ} \mathrm{F}\left(21.1^{\circ} \mathrm{C}\right)$ and $140^{\circ} \mathrm{F}\left(60.0^{\circ} \mathrm{C}\right)$. The cold air temperature was confined to between $59^{\circ} \mathrm{F}\left(15.0^{\circ} \mathrm{C}\right)$ and $63^{\circ} \mathrm{F}$ $\left(17.2^{\circ} \mathrm{C}\right)$.

Q. Case 17 -- Variable Air Volume (VAV) System for Interior Zones and DualDuct (DD) System for Perimeter Zones, Enthalpy Economy Cycle, Resetting Both Hot and Cold Decks

This case is similar to case 16 except that the interior system was replaced by a VAV system as described in case 9.

R. Case 18 -- Reheat (RH) System for Interior System and Variable Air Volume (VAV) System for Perimeter System, Enthalpy Economy

This case is a mixture of cases 7 and 9 . The interior reheat system of case 7 is combined with the perimeter VAV system of case 9.

S. Case 19 -- Reheat (RH) System for Interior Zones and Fan-Coil (FC) System for Perimeter Zones

The perimeter was simulated with four-pipe room fan-coil units. Because of the limitations of BLAST-2 program, only fan-coil units with direct outdoor air connections were modeled. The fan-coil unit fan pressure was assumed to be $0.8 \mathrm{in}$. of water $\left(2.0 \times 10^{2} \mathrm{~Pa}\right)$. Chilled water was turned off during nonoffice hours, although both hot water and chilled water were assumed to be available year-round. The BLAST default value of $45^{\circ} \mathrm{F}\left(7.2^{\circ} \mathrm{C}\right)$ 
for the entering chilled water temperature was used. The energy consumption for transporting the hot and chilled water to the fan-coil units was not included in the simulations. The interior system used the same reheat system as that of case 7 which had an enthalpy economy cycle and reset the supply air temperature by zone demand.

T. Case 20 -- Variable Air Volume (VAV) System for Interior Zones and Fan-Coil (FC) System for Perimeter Zones

In this case, the reheat system of case 19 was replaced by the VAV system of case 9, which used an enthalpy economy cycle. The perimeter fan-coil units were as described in case 19. 


\section{RESULTS AND DISCUSSION}

\subsection{ENERGY CONSUMPTION RESULTS*}

The yearly energy consumption for heating, cooling, and fan operation resulting from different strategies and combinations of strategies is listed for each of the six cities in tables 1 through 6 . Table 7 through 12 give the yearly heating, cooling, and fan energy consumption per unit floor area based on the total gross floor area of the building, for each of the six cities. These six tables also give the comparative energy consumption normalized to the consumption of the base reheat case (case 1). As described in section 2.3, cases 2 through 6 were single strategy cases, where only one control strategy was applied to the base reheat case so that the relative savings of the basic strategies may be judged. Case 7 is a combined strategy case -- using both the economy cycle and reset strategy for the reheat system. Variable air volume systems were compared in cases 8 and 9. In cases 1 to 9, the entire building used the same type of system and control strategies. Cases 10 through 17 combined reheat or variable air volume systems for the interior zones with dual-duct systems for the perimeter zones. Case 18 combined reheat interior zones with variable air volume perimeter zones. Cases 19 and 20 used perimeter fan-coil units with reheat and variable air volume in the interior zones, respectively.

The cooling and heating energy consumption results were also plotted against the cooling degree days and heating degree days. The reason for using degree days to correlate energy consumptions was given in reference 2 . It may be worthwhile to repeat it here:

"It is always desirable, from the application point of view, to have some parameters to correlate with the energy consumption data of one building so that the data may be applied to similar buildings of different climatic conditions. The authors of this paper realize the difficulty of finding these parameters to apply to commercial buildings. However, a parameter, even a crude one, may give HVAC designers assistance in deciding system and control strategies during the early course of the building design and provide budget figures for comparisons. This is not to say that the correlated data should be used indiscriminately. Detailed energy calculations with an appropriate method must be performed for a building in order to have accurate energy consumption values. Evidently one of the most influential parameters affecting a building energy consumption is the outdoor ambient dry-bulb temperature. The dry-bulb temperature changes the building energy consumption through ventilation air and building structure thermal conductance directly, and through ambient humidity indirectly. Some measures of the dry-bulb temperature for a climatic location are daily average temperature, monthly average temperature, degree-hour data, frequency data (BINs), etc. However, the most

* Energy consumption results are presented in English units only, for clarity. 
available data for most of the cities in the United States are the heating and cooling degree days." [2, page 7]

Figures 3 through 22 show the cooling energy consumption of the 20 strategies using $65^{\circ} \mathrm{F}\left(18.3^{\circ} \mathrm{C}\right)$ based cooling degree days as the independent variable. Figure 23 compares the cooling energy consumption of the single control strategy cases as well as the combined strategy case in which the entire building is served by reheat systems. Figure 24 compares the two variable air volume strategies -- one with minimum outside air only and one with enthalpy economy cycles. Figure 25 shows the cooling energy consumption where the interior system was of the variable air volume type and the perimeter zones were served by dual-duct system. Finally, figure 26 displays the better energy saving system/control strategy combinations. Figures 27 through 50 plot the corresponding heating energy consumption data for the six cities as a function of heating degree days using $65^{\circ} \mathrm{F}\left(18.3^{\circ} \mathrm{C}\right)$ as the base.

\subsection{COMPARISON OF STRATEGIES}

\section{A. Outside Air Economy Cycles}

Three different outside air economy cycles were applied to the reheat systems of the entire building. They were the temperature economy cycle which tried to maintain the mixed air temperature at that of the cold supply air temperature; the return air economy cycle which compared the return air temperature with the outside air temperature and admitted 100 percent outside air when the outside air temperature was lower than the return air temperature; and the enthalpy economy cycle which was similar to the return air economy cycle except that enthalpies were used for comparisons instead of temperatures.

In terms of cooling energy savings, generally the enthalpy economy cycle saved the most energy and the temperature economy cycle saved the least. A few exceptions can be noted. The temperature economy cycle did slightly better than the return air economy cycle for Lake Charles, and the return air economy cycle edged the enthalpy economy cycle in Santa Maria and Seattle. However, the differences in all three cases were within two percent of each other. The following table compares the economy cycle lists the annual energy consumption ratios of various cases for the six cities. 


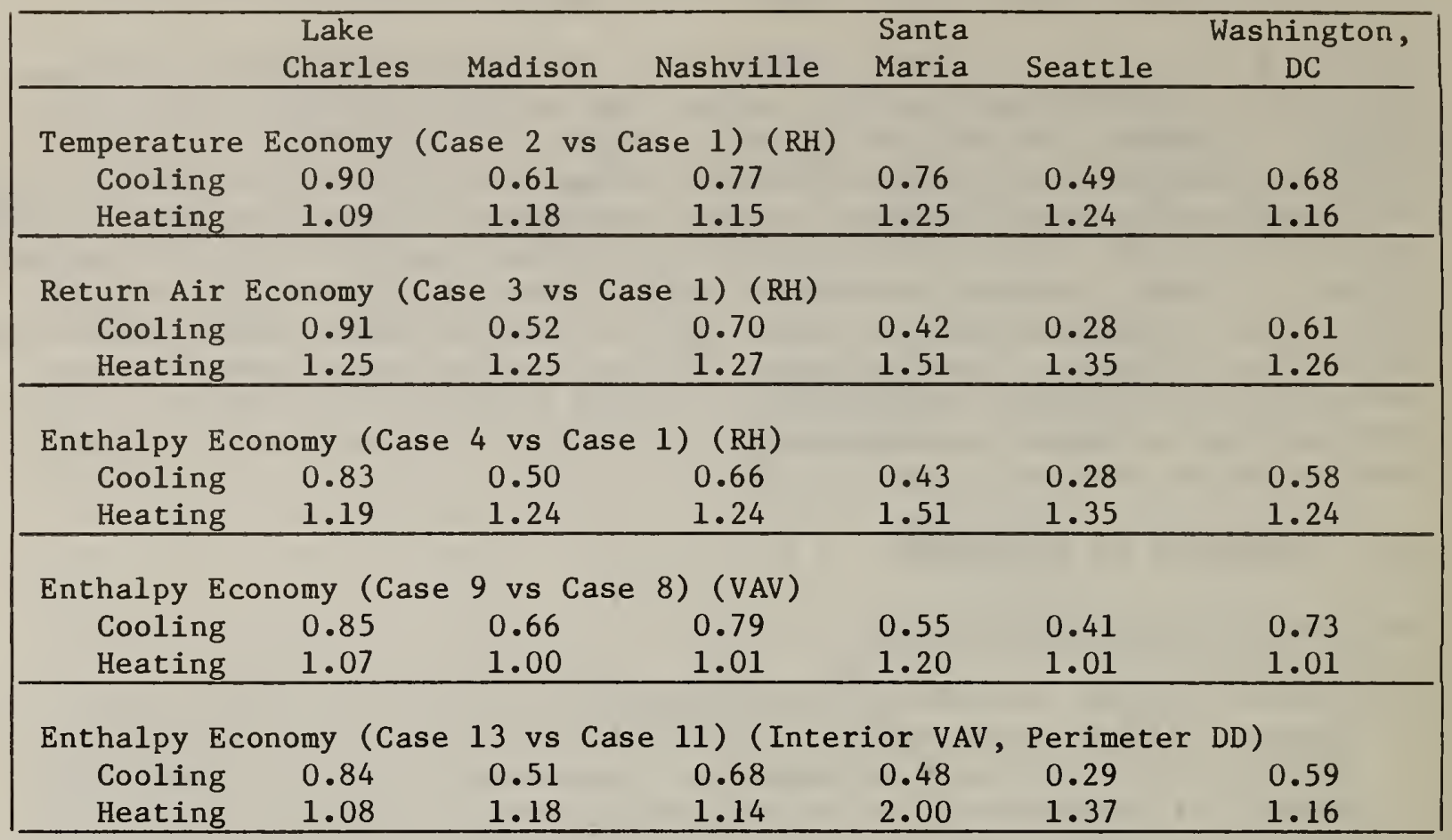

All comparisons in the above table are for single strategy cases. When other strategies were added to the economy cycles, the energy changes were not necessarily the same as indicated here. In all economy cycle cases, the cooling savings were partly offset by increases in heating energy increases. The reason for the increased heating energy was the decreased supply-air temperature. When the economy cycle was used, the cooling coil load decreased and the cooling-coil controller maintained a lower air temperature than the temperature would otherwise be, due to the controller throttling range effect. The economy cycle was usually in effect when the building was at part cooling load conditions so that the supply-air temperature to the spaces needed to be adjusted upward for most systems. The economy cycle cases, which are compared in the above table, all had fixed supply air temperature and flow rates, except for the VAV systems. Therefore, all the reheat and dual-duct systems needed either more reheating or more hot air mixing to compensate for the excessive cooling capacity, although the effect of this waste was dependent on the particular system. The self-adjusting nature of the VAV systems (case 9 vs case 8 ) avoided this waste by reducing the cooling capacities delivered to the spaces. The higher heating increases (although quite small) which were seen in Santa Maria probably could be reduced by using smaller minimum supply air ratios than the 20 percent used in the simulations. 
B. Supply Air Temperature Reset

For the single-strategy reheat systems, the supply air temperature was reset by sensing the outside air temperature (case 5, see paragraph 2.3.E) or by sensing the maximum cooling load demand zones (case 6, see paragraph 2.3.F). For the combined strategy reheat system, the enthalpy economy cycle was combined with the resetting of supply air by the latter strategy (case 7, see paragraph 2.3.G). The energy consumption of these three cases as compared to the base reheat case (case 1 ) is listed in tables 7 through 12 and is repeated below.

\begin{tabular}{|c|c|c|c|c|c|c|}
\hline & $\begin{array}{c}\text { Lake } \\
\text { Charles }\end{array}$ & Madison & Nashville & $\begin{array}{l}\text { Santa } \\
\text { Maria }\end{array}$ & Seattle & $\begin{array}{c}\text { Washington, } \\
\text { DC } \\
\end{array}$ \\
\hline \multicolumn{7}{|c|}{ Reset by Outside Air Temperature (Case 5 vs Case 1) (RH) } \\
\hline Cooling & 0.89 & 0.82 & 0.86 & 0.84 & 0.81 & 0.84 \\
\hline Heating & 0.78 & 0.88 & 0.84 & 0.72 & 0.87 & 0.87 \\
\hline \multicolumn{7}{|c|}{ Reset by Maximum Cooling Load Demand Zones (Case 6 vs Case 1) (RH) } \\
\hline Cooling & 0.75 & 0.64 & 0.70 & 0.76 & 0.62 & 0.67 \\
\hline Heating & 0.43 & 0.61 & 0.47 & 0.53 & 0.47 & 0.51 \\
\hline \multicolumn{7}{|c|}{$\begin{array}{l}\text { Enthalpy Economy and Reset by Maximum Cooling Load Demand Zones } \\
\text { (Case } 7 \text { vs Case 1) (RH) }\end{array}$} \\
\hline Cooling & 0.63 & 0.36 & 0.48 & 0.83 & 0.19 & 0.43 \\
\hline Heating & 0.57 & 0.85 & 0.69 & 0.88 & 0.81 & 0.76 \\
\hline
\end{tabular}

As stated previously, the supply air temperature of the outside air reset case was set at $59^{\circ} \mathrm{F}\left(15.0^{\circ} \mathrm{C}\right)$ when the outside air was $90^{\circ} \mathrm{F}\left(32.2^{\circ} \mathrm{C}\right)$, and at $63^{\circ} \mathrm{F}\left(17.2^{\circ} \mathrm{C}\right)$ when the outside air was $70^{\circ} \mathrm{F}\left(21.1^{\circ} \mathrm{C}\right)$. This reset schedule provided a good match between the system cooling capacity with the zone loads, yet it limited the space humidity to reasonable levels during off-peak hours. Case 5 did not reset the supply air for the interior zones. This resulted in lesser savings for case 5 than for cases 6 . For the same reason, a direct comparison of cases 5 and 6 , using the energy consumption numbers, is not appropriate. Both the heating and cooling energy savings of case 6 over case 1 were substantial. The addition of enthalpy economy cycles to the resetting strategy reduced the cooling energy demand. In the meantime, the heating energy requirement was drastically reduced from that of the enthalpy strategy alone (comparisons may be found in tables 7 through 12 or in the table under paragraph 3.2. A).

Resetting the dual-duct system temperature was simulated by either resetting the hot air temperature alone or by resetting both hot and cold air. The former strategy was popularly used even before energy savings became fashionable and was usually done by using the outside air temperature as the resetting parameter. The latter case is relatively new and may use control signals 
from the thermal zones to reset the air temperatures. A comparison of heating and cooling energy consumption for various dual-duct cases when combined with reheat interior system is shown in the following table. All cases used enthalpy economy cycles.

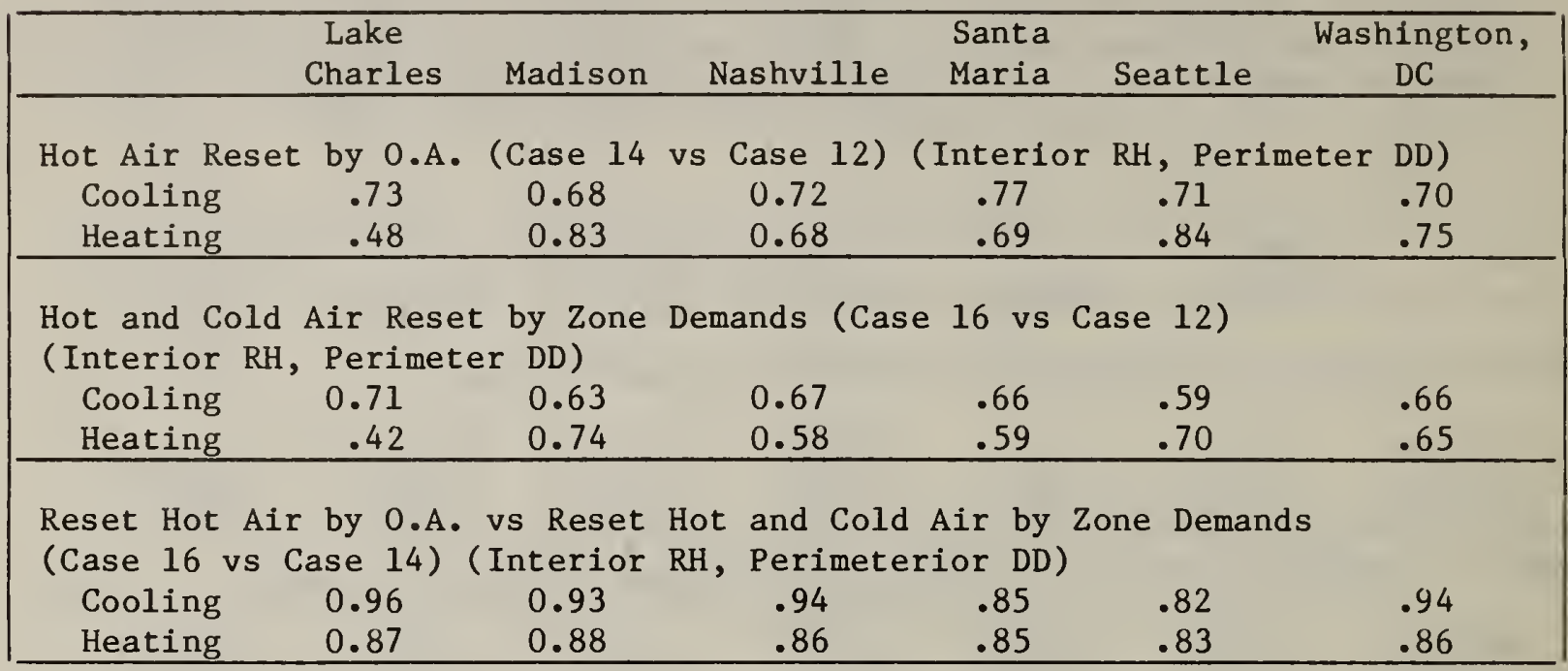

The same dual-duct strategies which were combined with variable air volume interior systems are compared below. Again, all cases had enthalpy economy cycles.

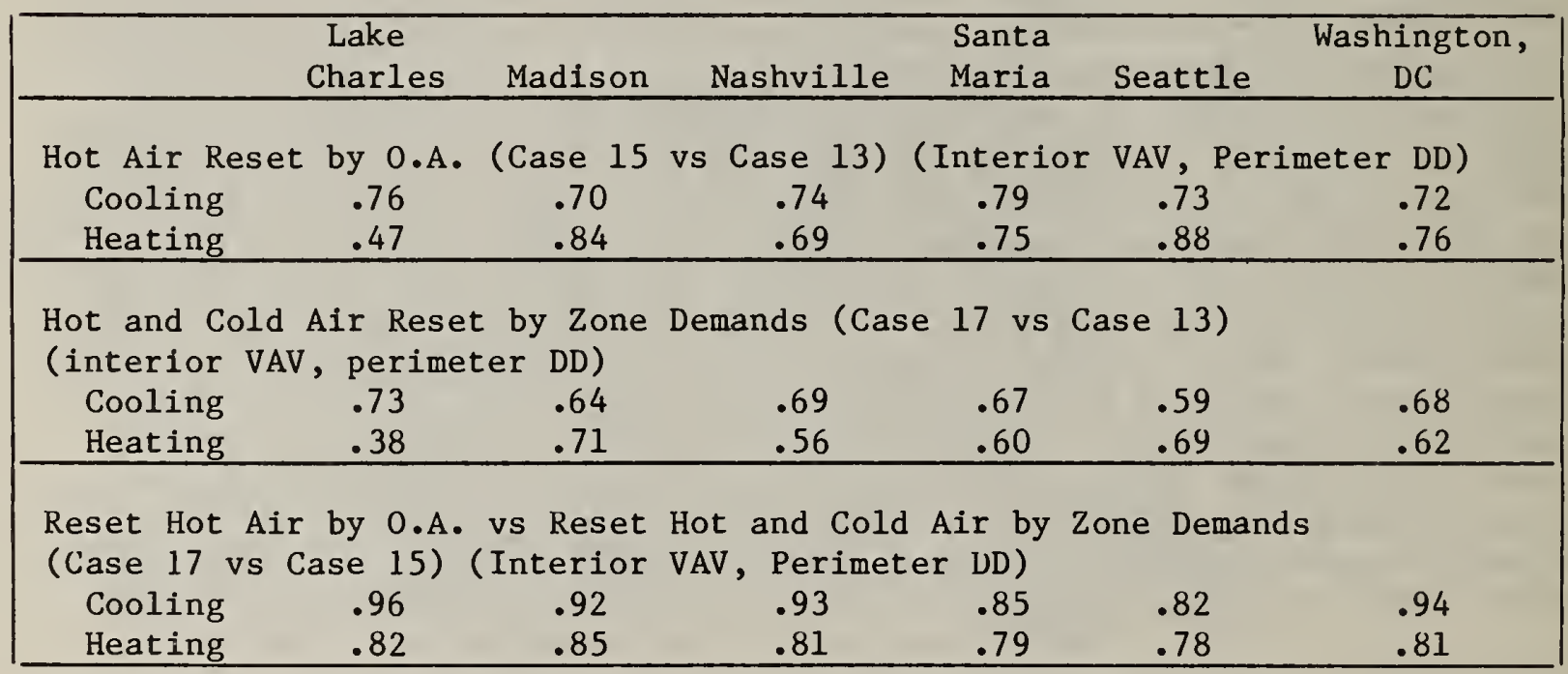

Both of the above tables indicate that the zone controlled reset of both hot and cold air saved more than the hot air reset controlled by the outside air temperature. The ratio of energy savings in these two tables are quite close, which reflects the rather constant interior load nature of 
the building, and perhaps a general characteristic of office interior zones.

\section{Fan-Coil Systems}

Cases 19 and 20 had four-pipe fan-coil systems for the perimeter zones, with the hot and cold water available year-round. A fixed amount of outside air was introduced directly to the fan-coil units during operating hours. In the following table, the heating and cooling energies are compared for the three combinations in the perimeter zone -- variable air volume, dual-duct, and fan-coil systems, and a variable air volume system for the interior zones. The variable air volume system energy consumption was used as the base for these comparisons.

\begin{tabular}{|c|c|c|c|c|c|c|}
\hline & $\begin{array}{c}\text { Lake } \\
\text { Charles }\end{array}$ & Madison & Nashville & $\begin{array}{l}\text { Santa } \\
\text { Maria }\end{array}$ & Seattle & $\begin{array}{l}\text { Washington, } \\
\text { DC }\end{array}$ \\
\hline $\begin{array}{c}\text { Dual-Duct vs } \\
\text { Cooling } \\
\text { Heating } \\
\end{array}$ & $\begin{array}{c}\text { VAV (Case } \\
1.13 \\
3.51 \\
\end{array}$ & $\begin{array}{r}17 \text { vs } \mathrm{Ca} \\
1.06 \\
1.65 \\
\end{array}$ & $\begin{array}{l}\text { e 9) } \\
1.10 \\
2.54 \\
\end{array}$ & $\begin{array}{r}1.00 \\
11.83 \\
\end{array}$ & $\begin{array}{l}0.99 \\
3.31 \\
\end{array}$ & $\begin{array}{l}1.17 \\
3.19 \\
\end{array}$ \\
\hline $\begin{array}{c}\text { Fan-Coil vs } \\
\text { Cooling } \\
\text { Heating }\end{array}$ & $\begin{array}{c}\text { VAV (Case } \\
0.93 \\
1.22\end{array}$ & $\begin{array}{c}20 \text { vs Cas } \\
0.93 \\
1.12\end{array}$ & 9) $\begin{array}{l}0.93 \\
1.24\end{array}$ & $\begin{array}{l}1.07 \\
1.78\end{array}$ & $\begin{array}{l}1.02 \\
1.40\end{array}$ & $\begin{array}{l}0.96 \\
1.24\end{array}$ \\
\hline
\end{tabular}

The much higher heating energy consumption for the dual-duct systems was explained in the previous section which dealt with outside air economy cycles. This was exaggerated in these comparisons by the extremely low heating energy consumption of the variable air systems in low heating degree day areas. In most cities, the energy consumption of the fan-coil unit systems compared closely with that of the variable air volume systems, because both systems tried to provide the heating or cooling capacities to match building loads. In comparing these two systems, the fan-coil system minimizes the losses from mixing the hot and cold energy in the air-handling system while giving up the benefit of using economy cycles. The relatively higher cooling energy consumption of fan-coil systems in Santa Maria and Seattle indicates the penalty of not using economy cycles for $f a n-c o i l$ systems in mild weather areas.

\section{Fan Energy Consumption}

The fan pressure requirements of the air handling system simulations performed in this study were given in the case descriptions. Several arbitrary assumptions about pressures were made for these simulations. Therefore, one should remember these assumptions when comparing the fan energy consumptions of different systems and strategies. The fan energy consumption ratios of the following table were selectively taken from tables 7 through 12. The energy consumption of reheat systems is given a base value of 1 . 


\begin{tabular}{|c|c|c|c|c|c|c|}
\hline & $\begin{array}{c}\text { Lake } \\
\text { Charles }\end{array}$ & Madison & Nashville & $\begin{array}{l}\text { Santa } \\
\text { Maria }\end{array}$ & Seattle & $\begin{array}{l}\text { Washington, } \\
\text { DC }\end{array}$ \\
\hline $\begin{array}{l}\text { RH (Case 1) } \\
\text { VAV (Case 9) }\end{array}$ & $\begin{array}{l}1.00 \\
0.60\end{array}$ & $\begin{array}{l}1.00 \\
0.53\end{array}$ & $\begin{array}{l}1.00 \\
0.56\end{array}$ & $\begin{array}{l}1.00 \\
0.60\end{array}$ & $\begin{array}{l}1.00 \\
0.49\end{array}$ & $\begin{array}{l}1.00 \\
0.47\end{array}$ \\
\hline $\begin{array}{l}\text { Interior VAV, } \\
\text { Interior VAV, }\end{array}$ & $\begin{array}{l}\text { Perimeter } \\
1.03 \\
\text { Perimeter } \\
0.53\end{array}$ & $\begin{array}{l}\text { Dual-Duct } \\
1.04 \\
\text { Fan-coil } \\
0.50\end{array}$ & $\begin{array}{c}\text { (Case 17) } \\
1.04 \\
(\text { Case 20) } \\
0.51\end{array}$ & 1.00 & 1.03 & 1.03 \\
\hline
\end{tabular}




\section{SUMMARY AND CONCLUSIONS}

The comparative energy consumption of different air-handling systems was simulated for a large high-rise office building. This simulation was performed for six cities representing various climatic conditions of the United States. These cities have $65^{\circ} \mathrm{F}$ based heating and cooling degree days which range from 1498 to 7730 for heating and from 84 to 2739 for cooling. The air handling systems simulated in the study included reheat, variable air volume, dual-duct and fan-coil systems. The control strategies studied included three economy cycles (temperature, return air, and enthalpy), two supply air temperature resettings (by outside air temperature and by zone load demand), and the combination of these strategies.

The total yearly energy consumption results for the different cities simulated are presented in tables 1 through 6 . The yearly energy consumption per unit floor area and the relative comparisons are shown in tables 7 through 12 . Figures 3 through 50 depict these results correlated with cooling and heating degree days.

Listed below are some of the major conclusions which can be drawn for this large office building, based on the parameters used in the study.

A. Based on a comparison of cooling energy consumption alone, the enthalpy economy cycle saved more than the return air economy cycle which, in turn, was better than the temperature economy cycle. At Santa Maria and Seattle where the cooling degree days were low, the cooling savings from both the enthalpy and return air economy cycles were similar.

B. Savings in cooling energy from using economy cycles were generally accompanied by an increase in required heating energy. Therefore, decisions to use economy cycles must be based on evaluating the overall savings of both cooling and heating energies. The increase in heating energy also depended on the type of air-handling system used. Dual-duct systems and reheat systems used more than variable air volume systems.

C. Greater predicted energy savings were obtained by resetting the supply air temperatures of both the hot and cold air in accordance with zone load demands than by using the outside air temperature as a reference.

D. Resetting the supply air temperature reduced building energy consumption. This strategy was especially beneficial when it was applied in combination with the economy cycles.

E. The energy consumptions of the variable air volume and fan-coil systems were significantly below those of reheat and dual-duct systems. This reflects the nature of the former two systems which try to match the system capacities to the ever changing building loads. The differences in energy consumptions of the variable air volume and fan-coil systems were relatively small. 
F. Substantial air transportation energy savings were obtained when variable air volume and fan-coil systems were used. Dual-duct systems used more energy for transporting air than the other systems compared in this study.

It should be mentioned again that the energy consumption predictions presented in this study were based on assumptions for a particular building using one set of construction, orientation, and internal loads. The energy consumption boundary of this study was at the energy inlets of the air handling systems. Therefore, plant efficiencies, energy transmission losses, and energy costs should also be considered in order to use the data given in this study for control strategy selections and for preliminary design purposes. 
REFERENCE

[1] Parken, W.H., Kao, J.Y., and Kelly, G.E., Strategies for Energy

Conservation in Small Office Buildings, U.S. National Bureau of Standards, NBSIR 82-2489, June 1982.

[2] Kao, J.Y., Parken, W.H., and Pierce, E.T., Strategies for Energy Conservation for a Large Retail Store, U.S. National Bureau of Standards, NBSIR 82-2580, September 1982.

[3] Nonresidential Buildings Energy Consumption Survey: Building Characteristics, U.S. Department of Energy, DOE/E2A-0246, March 1981.

[4] Hittle, D.C., The Building Loads Analysis System Thermodynamics (BLAST) Program, Version 2.0: Users Manual, Technical Report E-153, U.S. Army Construction Engineering Research Laboratory, Champaign, IL, June 1979.

[5] Grot, R.A., The Air Infiltration and Ventilation Rates in Two Large Commercial Buildings, presented at ASHRAE 1983 Semiannual Meeting, January 23-26, 1983.

[6] SOLMET Volume 1 - User's Manual, Hourly Solar Radiation - Surface Meteorological Observations, National Climatic Center, Ashville, NC, August 1978 .

[7] ASHRAE Handbook - 1981 Fundamentals Volume, Chapter 24, American Society of Heating, Refrigerating, and Air-Conditioning Engineers, Inc., Atlanta, GA, 1981 . 
Table 1. Annual Energy Consumption - Lake Charles, LA

\begin{tabular}{|c|c|c|c|c|c|}
\hline Case & \multicolumn{2}{|c|}{ Strategy } & $\begin{array}{r}\text { Heating Energy } \\
\text { Btu } \times 10^{9} \\
\end{array}$ & $\begin{array}{l}\text { Cooling Energy } \\
\text { Btu } \times 10^{9} \\
\end{array}$ & $\begin{array}{l}\text { Fan Energy } \\
\text { Btu } \times 10^{9} \\
\end{array}$ \\
\hline 1 & \multicolumn{2}{|l|}{ Base RH } & 5.99 & 15.08 & 2.35 \\
\hline 2 & \multicolumn{2}{|c|}{ Base RH + temperature economy } & 6.51 & 13.53 & 2.35 \\
\hline 3 & \multicolumn{2}{|c|}{ Base $\mathrm{RH}+$ return air economy } & 7.47 & 13.71 & 2.35 \\
\hline 4 & \multicolumn{2}{|c|}{ Base RH + enthalpy economy } & 7.14 & 12.45 & 2.35 \\
\hline 5 & \multicolumn{2}{|c|}{$\begin{array}{l}\text { Base } \mathrm{RH}+\text { supply air reset by } \\
\text { outside air }\end{array}$} & 6.69 & 13.40 & 2.35 \\
\hline 6 & \multicolumn{2}{|c|}{$\begin{array}{l}\text { Base } \mathrm{RH}+\text { supply air reset by } \\
\text { zone cooling demand }\end{array}$} & 5.56 & 11.29 & 2.35 \\
\hline 7 & \multicolumn{2}{|c|}{$\begin{array}{l}\text { Base } \mathrm{RH}+\text { enthalpy economy }+ \text { supply } \\
\text { air reset by zone cooling demand }\end{array}$} & 3.45 & 9.52 & 2.35 \\
\hline 8 & \multicolumn{2}{|l|}{ Base VAV } & 0.46 & 8.32 & 1.41 \\
\hline 9 & \multicolumn{2}{|c|}{ Case $8+$ enthalpy economy } & 0.49 & 7.09 & 1.40 \\
\hline 10 & $\begin{array}{l}\text { Interior } \\
\text { Perimeter }\end{array}$ & $\begin{array}{l}\text { base RH } \\
\text { base DD }\end{array}$ & 5.25 & 14.28 & 2.58 \\
\hline 11 & $\begin{array}{l}\text { Interior } \\
\text { Perimeter }\end{array}$ & $\begin{array}{l}\text { base VAV } \\
\text { base DD }\end{array}$ & 4.15 & 13.09 & 2.42 \\
\hline 12 & $\begin{array}{l}\text { Interior } \\
\text { Perimeter }\end{array}$ & $\begin{array}{l}\text { base } \mathrm{RH}+\text { enthalpy economy } \\
\text { base } \mathrm{DD}+\text { enthalpy economy }\end{array}$ & 6.64 & 11.76 & 2.58 \\
\hline 13 & $\begin{array}{l}\text { Interior } \\
\text { Perimeter }\end{array}$ & $\begin{array}{l}\text { base VAV + enthalpy economy } \\
\text { base } \mathrm{DD}+\text { enthalpy economy }\end{array}$ & 4.47 & 10.94 & 2.41 \\
\hline 14 & $\begin{array}{l}\text { Interior } \\
\text { Perimeter }\end{array}$ & $\begin{array}{l}\text { base } \mathrm{RH}+\text { enthalpy econmy } \\
\text { base } \mathrm{DD}+\text { enthalpy economy }+ \\
\text { hot deck reset by } 0 . \mathrm{A} \text {. }\end{array}$ & 3.18 & 8.63 & 2.58 \\
\hline 15 & $\begin{array}{l}\text { Interfor } \\
\text { Perimeter }\end{array}$ & $\begin{array}{l}\text { Base VAV + enthalpy economy } \\
\text { Base DD + enthalpy economy }+ \\
\text { hot deck reset by } 0 . A \text {. }\end{array}$ & 2.11 & 8.31 & 2.41 \\
\hline 16 & $\begin{array}{l}\text { Interior } \\
\text { Perimeter }\end{array}$ & $\begin{array}{l}\text { base } \mathrm{RH}+\text { enthalpy economy }+ \\
\text { supply air reset by zone demand } \\
\text { base DD }+ \text { enthalpy economy }+ \\
\text { hot and cold decks reset by } \\
\text { zone demand }\end{array}$ & 2.78 & 3.31 & 2.58 \\
\hline 17 & $\begin{array}{l}\text { Interior } \\
\text { Perimeter }\end{array}$ & $\begin{array}{l}\text { base VAV + enthalpy economy } \\
\text { base DD + enthalpy economy }+ \\
\text { hot and cold decks reset by } \\
\text { zone demand }\end{array}$ & 1.72 & 7.98 & 2.41 \\
\hline 18 & $\begin{array}{l}\text { Interior } \\
\text { Perimeter }\end{array}$ & $\begin{array}{l}\text { base } \mathrm{RH}+\text { enthalpy economy }+ \\
\text { supply air reset by zone demand } \\
\text { base VAV }+ \text { enthalpy economy }\end{array}$ & 1.55 & 7.62 & 1.58 \\
\hline 19 & $\begin{array}{l}\text { Interior } \\
\text { Perimeter }\end{array}$ & $\begin{array}{l}\text { base } \mathrm{RH}+\text { enthalpy economy }+ \\
\text { supply air reset by zone demand } \\
\text { FC }\end{array}$ & 1.63 & 6.92 & 1.41 \\
\hline 20 & $\begin{array}{l}\text { Interfor } \\
\text { Perimeter }\end{array}$ & $\begin{array}{l}\text { base VAV + enthalpy economy } \\
\text { FC }\end{array}$ & 0.56 & 6.60 & 1.24 \\
\hline
\end{tabular}


Table 2. Annual Energy Consumption - Madison, WI

\begin{tabular}{|c|c|c|c|c|c|}
\hline Case & \multicolumn{2}{|c|}{ Strategy } & $\begin{array}{l}\text { Heating Energy } \\
\text { Btu } \times 10^{9}\end{array}$ & $\begin{array}{l}\text { Cooling Energy } \\
\text { Btu } \times 10^{9}\end{array}$ & $\begin{array}{l}\text { Fan Energy } \\
\text { Btu } \times 10^{9} \\
\end{array}$ \\
\hline 1 & \multicolumn{2}{|l|}{ Base RH } & 9.41 & 10.57 & 2.85 \\
\hline 2 & \multicolumn{2}{|c|}{ Base $\mathrm{RH}+$ temperature economy } & 11.08 & 6.45 & 2.85 \\
\hline 3 & \multicolumn{2}{|c|}{ Base $\mathrm{RH}+$ return air economy } & 11.73 & 5.45 & 2.85 \\
\hline 4 & \multicolumn{2}{|c|}{ Base RH + enthalpy economy } & 11.66 & 5.26 & 2.85 \\
\hline 5 & \multicolumn{2}{|c|}{$\begin{array}{l}\text { Base } \mathrm{RH}+\text { supply alr reset by } \\
\text { outside alr }\end{array}$} & 8.26 & 8.68 & 2.85 \\
\hline 6 & \multicolumn{2}{|c|}{$\begin{array}{l}\text { Base } \mathrm{RH}+\text { supply air reset by } \\
\text { zone cooling demand }\end{array}$} & 5.77 & 6.81 & 2.85 \\
\hline 7 & \multicolumn{2}{|c|}{$\begin{array}{l}\text { Base } \mathrm{RH}+\text { enthalpy economy + supply } \\
\text { alr reset by zone cooling demand }\end{array}$} & 8.00 & 3.85 & 2.85 \\
\hline 8 & \multicolumn{2}{|l|}{ Base VAV } & 4.07 & 4.31 & 1.53 \\
\hline 9 & \multicolumn{2}{|c|}{ Case $8+$ enthalpy economy } & 4.09 & 2.83 & 1.52 \\
\hline 10 & $\begin{array}{l}\text { Interior } \\
\text { Perimeter }\end{array}$ & $\begin{array}{l}\text { base } \mathrm{RH} \\
\text { base } \mathrm{DD}\end{array}$ & 9.29 & 10.27 & 3.15 \\
\hline 11 & $\begin{array}{l}\text { Interior } \\
\text { Perimeter }\end{array}$ & $\begin{array}{l}\text { base VAV } \\
\text { base DD }\end{array}$ & 8.06 & 9.17 & 2.97 \\
\hline 12 & $\begin{array}{l}\text { Interior } \\
\text { Perimeter }\end{array}$ & $\begin{array}{l}\text { base RH + enthalpy economy } \\
\text { base } D D+\text { enthalpy economy }\end{array}$ & 12.29 & 4.99 & 3.15 \\
\hline 13 & $\begin{array}{l}\text { Interior } \\
\text { Perimeter }\end{array}$ & $\begin{array}{l}\text { base VAV + enthalpy economy } \\
\text { base DD + enthalpy economy }\end{array}$ & 9.53 & 4.65 & 2.96 \\
\hline 14 & $\begin{array}{l}\text { Interior } \\
\text { Perimeter }\end{array}$ & $\begin{array}{l}\text { base } \mathrm{RH}+\text { enthalpy econmy } \\
\text { base } \mathrm{DD}+\text { enthalpy economy }+ \\
\text { hot deck reset by } 0 . \mathrm{A} \text {. }\end{array}$ & 10.24 & 3.39 & 3.15 \\
\hline 15 & $\begin{array}{l}\text { Interior } \\
\text { Perimeter }\end{array}$ & $\begin{array}{l}\text { Base VAV + enthalpy economy } \\
\text { Base DD + enthalpy economy + } \\
\text { hot deck reset by } 0 . A \text {. }\end{array}$ & 7.99 & 3.24 & 2.96 \\
\hline 16 & $\begin{array}{l}\text { Interior } \\
\text { Perimeter }\end{array}$ & $\begin{array}{l}\text { base RH + enthalpy economy }+ \\
\text { supply air reset by zone demand } \\
\text { base DD + enthalpy economy }+ \\
\text { hot and cold decks reset by } \\
\text { zone demand }\end{array}$ & 9.05 & 3.14 & 3.15 \\
\hline 17 & $\begin{array}{l}\text { Interior } \\
\text { Perimeter }\end{array}$ & $\begin{array}{l}\text { base VAV + enthalpy economy } \\
\text { base DD + enthalpy economy }+ \\
\text { hot and cold decks reset by } \\
\text { zone demand }\end{array}$ & 6.76 & 2.99 & 2.96 \\
\hline 18 & $\begin{array}{l}\text { Interior } \\
\text { Perimeter }\end{array}$ & $\begin{array}{l}\text { base } \mathrm{RH}+\text { enthalpy economy }+ \\
\text { supply air reset by zone demand } \\
\text { base VAV + enthalpy economy }\end{array}$ & 6.52 & 2.97 & 1.71 \\
\hline 19 & $\begin{array}{l}\text { Interior } \\
\text { Perimeter }\end{array}$ & $\begin{array}{l}\text { base } \mathrm{RH}+\text { enthalpy economy }+ \\
\text { supply air reset by zone demand } \\
\text { FC }\end{array}$ & 7.03 & 2.78 & 1.61 \\
\hline 20 & $\begin{array}{l}\text { Interior } \\
\text { Perimeter }\end{array}$ & $\begin{array}{l}\text { base VAV + enthalpy economy } \\
\text { FC }\end{array}$ & 4.59 & 2.63 & 1.42 \\
\hline
\end{tabular}


Table 3. Annual Energy Consumption - Nashville, TN

\begin{tabular}{|c|c|c|c|c|c|}
\hline Case & \multicolumn{2}{|c|}{ Strategy } & $\begin{array}{l}\text { Heating Energy } \\
\text { Btu } \times 10^{9}\end{array}$ & $\begin{array}{c}\text { Coollng Energy } \\
\text { Btu } \times 10^{9}\end{array}$ & $\begin{array}{l}\text { Fan Energy } \\
\text { Btu } \times 10^{9} \\
\end{array}$ \\
\hline 1 & \multicolumn{2}{|l|}{ Base RH } & 7.09 & 13.17 & 2.58 \\
\hline 2 & \multicolumn{2}{|c|}{ Base RH + temperature economy } & 8.17 & 10.08 & 2.58 \\
\hline 3 & \multicolumn{2}{|c|}{ Base $\mathrm{RH}+$ return air economy } & 8.97 & 9.23 & 2.58 \\
\hline 4 & \multicolumn{2}{|c|}{ Base RH + enthalpy economy } & 8.77 & 8.71 & 2.58 \\
\hline 5 & \multicolumn{2}{|c|}{$\begin{array}{l}\text { Base } \mathrm{RH}+\text { supply air reset by } \\
\text { outside alr }\end{array}$} & 5.94 & 11.31 & 2.58 \\
\hline 6 & \multicolumn{2}{|c|}{$\begin{array}{l}\text { Base } R H+\text { supply air reset by } \\
\text { zone coolling demand }\end{array}$} & 3.37 & 9.21 & 2.58 \\
\hline 7 & \multicolumn{2}{|c|}{$\begin{array}{l}\text { Base } R H+\text { enthalpy economy + supply } \\
\text { air reset by } z \text { one cooling demand }\end{array}$} & 4.89 & 6.27 & 2.58 \\
\hline 8 & \multicolumn{2}{|l|}{ Base VAV } & 1.35 & 6.08 & 1.47 \\
\hline 9 & \multicolumn{2}{|c|}{ Case $8+$ enthalpy economy } & 1.37 & 4.82 & 1.46 \\
\hline 10 & $\begin{array}{l}\text { Interior } \\
\text { Perimeter }\end{array}$ & $\begin{array}{l}\text { base } \mathrm{RH} \\
\text { base } \mathrm{DD}\end{array}$ & 6.61 & 12.58 & 2.85 \\
\hline 11 & $\begin{array}{l}\text { Interior } \\
\text { Perimeter }\end{array}$ & $\begin{array}{l}\text { base VAV } \\
\text { base DD }\end{array}$ & 5.45 & 11.41 & 2.69 \\
\hline 12 & $\begin{array}{l}\text { Interior } \\
\text { Perimeter }\end{array}$ & $\begin{array}{l}\text { base RH + enthalpy economy } \\
\text { base DD + enthalpy economy }\end{array}$ & 8.79 & 8.26 & 2.85 \\
\hline 13 & $\begin{array}{l}\text { Interfor } \\
\text { Perimeter }\end{array}$ & $\begin{array}{l}\text { base VAV + enthalpy economy } \\
\text { base DD + enthalpy economy }\end{array}$ & 6.21 & 7.71 & 2.68 \\
\hline 14 & $\begin{array}{l}\text { Interior } \\
\text { Perimeter }\end{array}$ & $\begin{array}{l}\text { base } \mathrm{RH}+\text { enthalpy econmy } \\
\text { base } \mathrm{DD}+\text { enthalpy economy }+ \\
\text { hot deck reset by } 0 . \mathrm{A} \text {. }\end{array}$ & 5.94 & 5.92 & 2.85 \\
\hline 15 & $\begin{array}{l}\text { Interior } \\
\text { Perimeter }\end{array}$ & $\begin{array}{l}\text { Base VAV + enthalpy economy } \\
\text { Base DD }+ \text { enthalpy economy }+ \\
\text { hot deck reset by } 0 . A \text {. }\end{array}$ & 4.30 & 5.69 & 2.68 \\
\hline 16 & $\begin{array}{l}\text { Interior } \\
\text { Perimeter }\end{array}$ & $\begin{array}{l}\text { base } \mathrm{RH}+\text { enthalpy economy }+ \\
\text { supply air reset by zone demand } \\
\text { base DD }+ \text { enthalpy economy }+ \\
\text { hot and cold decks reset by } \\
\text { zone demand }\end{array}$ & 5.09 & 5.55 & 2.85 \\
\hline 17 & $\begin{array}{l}\text { Interior } \\
\text { Perimeter }\end{array}$ & $\begin{array}{l}\text { base VAV + enthalpy economy } \\
\text { base DD + enthalpy economy }+ \\
\text { hot and cold decks reset by } \\
\text { zone demand }\end{array}$ & 3.48 & 5.32 & 2.68 \\
\hline 18 & $\begin{array}{l}\text { Interior } \\
\text { Perimeter }\end{array}$ & $\begin{array}{l}\text { base } \mathrm{RH}+\text { enthalpy economy }+ \\
\text { supply air reset by zone demand } \\
\text { base VAV + enthalpy economy }\end{array}$ & 2.93 & 5.05 & 1.63 \\
\hline 19 & $\begin{array}{l}\text { Interior } \\
\text { Perimeter }\end{array}$ & $\begin{array}{l}\text { base } \mathrm{RH}+\text { enthalpy economy }+ \\
\text { supply air reset by zone demand } \\
\text { FC }\end{array}$ & 3.27 & 4.73 & 1.49 \\
\hline 20 & $\begin{array}{l}\text { Interior } \\
\text { Perimeter }\end{array}$ & $\begin{array}{l}\text { base VAV + enthalpy economy } \\
\text { FC }\end{array}$ & 1.70 & 4.50 & 1.32 \\
\hline
\end{tabular}


Table 4. Annual Energy Consumption - Santa Maria, CA

\begin{tabular}{|c|c|c|c|c|c|}
\hline Case & \multicolumn{2}{|c|}{ Strategy } & $\begin{array}{l}\text { Heating Energy } \\
\text { Btu } \times 10^{9}\end{array}$ & $\begin{array}{c}\text { Cooling Energy } \\
\text { Btu } \times 10^{9}\end{array}$ & $\begin{array}{l}\text { Fan Energy } \\
\text { Btu } \times 10^{9} \\
\end{array}$ \\
\hline 1 & \multicolumn{2}{|l|}{ Base RH } & 4.98 & 10.04 & 1.79 \\
\hline 2 & \multicolumn{2}{|c|}{ Base $\mathrm{RH}+$ temperature economy } & 6.21 & 7.79 & 1.79 \\
\hline 3 & \multicolumn{2}{|c|}{ Base $\mathrm{RH}+$ return air economy } & 7.52 & 4.25 & 1.79 \\
\hline 4 & \multicolumn{2}{|c|}{ Base RH + enthalpy economy } & 7.51 & 4.32 & 1.79 \\
\hline 5 & \multicolumn{2}{|c|}{$\begin{array}{l}\text { Base } \mathrm{RH}+\text { supply air reset by } \\
\text { outside air }\end{array}$} & 3.61 & 8.47 & 1.79 \\
\hline 6 & \multicolumn{2}{|c|}{$\begin{array}{l}\text { Base } \mathrm{RH}+\text { supply air reset by } \\
\text { zone cooling demand }\end{array}$} & 2.65 & 7.66 & 1.79 \\
\hline 7 & \multicolumn{2}{|c|}{$\begin{array}{l}\text { Base } \mathrm{RH}+\text { enthalpy economy + supply } \\
\text { air reset by zone cooling demand }\end{array}$} & 4.36 & 3.30 & 1.79 \\
\hline 8 & \multicolumn{2}{|l|}{ Base VAV } & 0.30 & 4.69 & 1.08 \\
\hline 9 & \multicolumn{2}{|c|}{ Case $8+$ enthalpy economy } & 0.36 & 2.56 & 1.07 \\
\hline 10 & $\begin{array}{l}\text { Interior } \\
\text { Perimeter }\end{array}$ & $\begin{array}{l}\text { base } \mathrm{RH} \\
\text { base } \mathrm{DD}\end{array}$ & 4.67 & 9.67 & 1.95 \\
\hline 11 & $\begin{array}{l}\text { Interior } \\
\text { Perimeter }\end{array}$ & $\begin{array}{l}\text { base VAV } \\
\text { base DD }\end{array}$ & 3.57 & 8.57 & 1.81 \\
\hline 12 & $\begin{array}{l}\text { Interior } \\
\text { Perimeter }\end{array}$ & $\begin{array}{l}\text { base } \mathrm{RH}+\text { enthalpy economy } \\
\text { base } \mathrm{DD}+\text { enthalpy economy }\end{array}$ & 7.63 & 4.11 & 1.95 \\
\hline 13 & $\begin{array}{l}\text { Interior } \\
\text { Perimeter }\end{array}$ & $\begin{array}{l}\text { base } \mathrm{VAV}+\text { enthalpy economy } \\
\text { base } \mathrm{DD}+\text { enthalpy economy }\end{array}$ & 7.13 & 3.83 & 1.79 \\
\hline 14 & $\begin{array}{l}\text { Interior } \\
\text { Perimeter }\end{array}$ & $\begin{array}{l}\text { base } \mathrm{RH}+\text { enthalpy econmy } \\
\text { base } \mathrm{DD}+\text { enthalpy economy }+ \\
\text { hot deck reset by } 0 . \mathrm{A} \text {. }\end{array}$ & 6.26 & 3.16 & 1.95 \\
\hline 15 & $\begin{array}{l}\text { Interior } \\
\text { Perimeter }\end{array}$ & $\begin{array}{l}\text { Base VAV + enthalpy economy } \\
\text { Base DD + enthalpy economy }+ \\
\text { hot deck reset by } 0 . A \text {. }\end{array}$ & 5.36 & 3.02 & 1.79 \\
\hline 16 & $\begin{array}{l}\text { Interior } \\
\text { Perimeter }\end{array}$ & $\begin{array}{l}\text { base } \mathrm{RH}+\text { enthalpy economy }+ \\
\text { supply air reset by zone demand } \\
\text { base DD + enthalpy economy }+ \\
\text { hot and cold decks reset by } \\
\text { zone demand }\end{array}$ & 4.47 & 2.70 & 1.95 \\
\hline 17 & $\begin{array}{l}\text { Interior } \\
\text { Perimeter }\end{array}$ & $\begin{array}{l}\text { base VAV + enthalpy economy } \\
\text { base DD + enthalpy economy }+ \\
\text { hot and cold decks reset by } \\
\text { zone demand }\end{array}$ & 4.26 & 2.57 & 1.79 \\
\hline 18 & $\begin{array}{l}\text { Interior } \\
\text { Perimeter }\end{array}$ & $\begin{array}{l}\text { base } \mathrm{RH}+\text { enthalpy economy }+ \\
\text { supply air reset by zone demand } \\
\text { base VAV + enthalpy economy }\end{array}$ & 2.08 & 2.69 & 1.22 \\
\hline 19 & $\begin{array}{l}\text { Interior } \\
\text { Perimeter }\end{array}$ & $\begin{array}{l}\text { base } \mathrm{RH}+\text { enthalpy economy }+ \\
\text { supply air reset by zone demand } \\
\text { FC }\end{array}$ & 2.35 & 2.88 & 1.13 \\
\hline 20 & $\begin{array}{l}\text { Interior } \\
\text { Perimeter }\end{array}$ & $\begin{array}{l}\text { base VAV + enthalpy economy } \\
\text { FC }\end{array}$ & 0.64 & 2.75 & 0.98 \\
\hline
\end{tabular}


Table 5. Annual Energy Consumption - Seattle, WA

\begin{tabular}{|c|c|c|c|c|c|}
\hline Case & \multicolumn{2}{|c|}{ Strategy } & $\begin{array}{l}\text { Heating Energy } \\
\text { Btu } \times 10^{9}\end{array}$ & $\begin{array}{c}\text { Cooling Energy } \\
\text { Btu } \times 10^{9}\end{array}$ & $\begin{array}{l}\text { Fan Energy } \\
\text { Btu } \times 10^{9}\end{array}$ \\
\hline 1 & \multicolumn{2}{|l|}{ Base RH } & 7.16 & 10.03 & 2.48 \\
\hline 2 & \multicolumn{2}{|c|}{ Base RH + temperature economy } & 8.86 & 4.89 & 2.48 \\
\hline 3 & \multicolumn{2}{|c|}{ Base $\mathrm{RH}+$ return a1r economy } & 9.68 & 2.76 & 2.48 \\
\hline 4 & \multicolumn{2}{|c|}{ Base RH + enthalpy economy } & 9.68 & 2.78 & 2.48 \\
\hline 5 & \multicolumn{2}{|c|}{$\begin{array}{l}\text { Base } \mathrm{RH}+\text { supply air reset by } \\
\text { outslde alr }\end{array}$} & 6.22 & 8.14 & 2.48 \\
\hline 6 & \multicolumn{2}{|c|}{$\begin{array}{l}\text { Base } \mathrm{RH}+\text { supply air reset by } \\
\text { zone coollng demand }\end{array}$} & 3.40 & 6.22 & 2.48 \\
\hline 7 & \multicolumn{2}{|c|}{$\begin{array}{l}\text { Base } \mathrm{RH}+\text { enthalpy economy + supply } \\
\text { air reset by zone cooling demand }\end{array}$} & 5.79 & 1.89 & 2.48 \\
\hline 8 & \multicolumn{2}{|l|}{ Base VAV } & 1.62 & 3.65 & 1.22 \\
\hline 9 & \multicolumn{2}{|c|}{ Case $8+$ enthalpy economy } & 1.64 & 1.48 & 1.21 \\
\hline 10 & $\begin{array}{l}\text { Interior } \\
\text { Perimeter }\end{array}$ & $\begin{array}{l}\text { base } \mathrm{RH} \\
\text { base } \mathrm{DD}\end{array}$ & 6.92 & 9.69 & 2.71 \\
\hline 11 & $\begin{array}{l}\text { Interior } \\
\text { Perimeter }\end{array}$ & $\begin{array}{l}\text { base VAV } \\
\text { base } D D\end{array}$ & 5.76 & 8.58 & 2.57 \\
\hline 12 & $\begin{array}{l}\text { Interior } \\
\text { Perimeter }\end{array}$ & $\begin{array}{l}\text { base } \mathrm{RH}+\text { enthalpy economy } \\
\text { base } \mathrm{DD}+\text { enthalpy economy }\end{array}$ & 10.21 & 2.63 & 2.71 \\
\hline 13 & $\begin{array}{l}\text { Interior } \\
\text { Perimeter }\end{array}$ & $\begin{array}{l}\text { base VAV + enthalpy economy } \\
\text { base DD + enthalpy economy }\end{array}$ & 7.88 & 2.46 & 2.55 \\
\hline 14 & $\begin{array}{l}\text { Interior } \\
\text { Perimeter }\end{array}$ & $\begin{array}{l}\text { base } \mathrm{RH}+\text { enthalpy econmy } \\
\text { base } \mathrm{DD}+\text { enthalpy economy }+ \\
\text { hot deck reset by } \mathrm{O.A} \text {. }\end{array}$ & 8.56 & 1.87 & 2.71 \\
\hline 15 & $\begin{array}{l}\text { Interior } \\
\text { Perimeter }\end{array}$ & $\begin{array}{l}\text { Base VAV + enthalpy economy } \\
\text { Base DD + enthalpy economy + } \\
\text { hot deck reset by O.A. }\end{array}$ & 6.97 & 1.79 & 2.55 \\
\hline 16 & $\begin{array}{l}\text { Interior } \\
\text { Perimeter }\end{array}$ & $\begin{array}{l}\text { base } \mathrm{RH}+\text { enthalpy economy }+ \\
\text { supply air reset by zone demand } \\
\text { base } \mathrm{DD}+\text { enthalpy economy }+ \\
\text { hot and cold decks reset by } \\
\text { zone demand }\end{array}$ & 7.13 & 1.54 & 2.71 \\
\hline 17 & $\begin{array}{l}\text { Interior } \\
\text { Perimeter }\end{array}$ & $\begin{array}{l}\text { base } \mathrm{VAV}+\text { enthalpy economy } \\
\text { base } \mathrm{DD}+\text { enthalpy economy }+ \\
\text { hot and cold decks reset by } \\
\text { zone demand }\end{array}$ & 5.43 & 1.46 & 2.55 \\
\hline 18 & $\begin{array}{l}\text { Interior } \\
\text { Perimeter }\end{array}$ & $\begin{array}{l}\text { base } \mathrm{RH}+\text { enthalpy economy }+ \\
\text { supply air reset by zone demand } \\
\text { base VAV + enthalpy economy }\end{array}$ & 3.81 & 1.56 & 1.37 \\
\hline 19 & $\begin{array}{l}\text { Interior } \\
\text { Perimeter }\end{array}$ & $\begin{array}{l}\text { base } \mathrm{RH}+\text { enthalpy economy }+ \\
\text { supply air reset by zone demand } \\
\text { FC }\end{array}$ & 4.47 & 1.59 & 1.42 \\
\hline 20 & $\begin{array}{l}\text { Interior } \\
\text { Per1meter }\end{array}$ & $\begin{array}{l}\text { base VAV + enthalpy economy } \\
\text { FC }\end{array}$ & 2.30 & 1.51 & 1.25 \\
\hline
\end{tabular}


Table 6. Annual Energy Consumption - Washington, D.C.

\begin{tabular}{|c|c|c|c|c|c|}
\hline Case & \multicolumn{2}{|c|}{ Strategy } & $\begin{array}{l}\text { Heating Energy } \\
\text { Btu } \times 10^{9} \\
\end{array}$ & $\begin{array}{l}\text { Cooling Energy } \\
\text { Btu } \times 10^{9}\end{array}$ & $\begin{array}{l}\text { Fan Energy } \\
\text { Btu } \times 10^{9} \\
\end{array}$ \\
\hline 1 & \multicolumn{2}{|l|}{ Base RH } & 7.80 & 12.29 & 2.74 \\
\hline 2 & \multicolumn{2}{|c|}{ Base RH + temperature economy } & 9.05 & 8.37 & 2.74 \\
\hline 3 & \multicolumn{2}{|c|}{ Base $\mathrm{RH}+$ return air economy } & 9.82 & 7.54 & 2.74 \\
\hline 4 & \multicolumn{2}{|c|}{ Base RH + enthalpy economy } & 9.68 & 7.12 & 2.74 \\
\hline 5 & \multicolumn{2}{|c|}{$\begin{array}{l}\text { Base } \mathrm{RH}+\text { supply alr reset by } \\
\text { outside air }\end{array}$} & 6.76 & 10.37 & 2.74 \\
\hline 6 & \multicolumn{2}{|c|}{$\begin{array}{l}\text { Base } \mathrm{RH}+\text { supply air reset by } \\
\text { zone cooling demand }\end{array}$} & 3.98 & 8.28 & 2.74 \\
\hline 7 & \multicolumn{2}{|c|}{$\begin{array}{l}\text { Base } \mathrm{RH}+\text { enthalpy economy + supply } \\
\text { air reset by zone cooling demand }\end{array}$} & 5.91 & 5.24 & 2.74 \\
\hline 8 & \multicolumn{2}{|l|}{ Base VAV } & 1.97 & 5.19 & 1.31 \\
\hline 9 & \multicolumn{2}{|c|}{ Case $8+$ enthalpy economy } & 1.99 & 3.78 & 1.30 \\
\hline 10 & $\begin{array}{l}\text { Interior } \\
\text { Perimeter }\end{array}$ & $\begin{array}{l}\text { base } \mathrm{RH} \\
\text { base } \mathrm{DD}\end{array}$ & 7.36 & 11.75 & 3.01 \\
\hline 11 & $\begin{array}{l}\text { Interior } \\
\text { Perimeter }\end{array}$ & $\begin{array}{l}\text { base VAV } \\
\text { base DD }\end{array}$ & 6.17 & 10.59 & 2.85 \\
\hline 12 & $\begin{array}{l}\text { Interior } \\
\text { Perimeter }\end{array}$ & $\begin{array}{l}\text { base RH + enthalpy economy } \\
\text { base } D D+\text { enthalpy economy }\end{array}$ & 9.84 & 6.73 & 3.01 \\
\hline 13 & $\begin{array}{l}\text { Interior } \\
\text { Perimeter }\end{array}$ & $\begin{array}{l}\text { base VAV + enthalpy economy } \\
\text { base DD + enthalpy economy }\end{array}$ & 7.15 & 6.26 & 2.83 \\
\hline 14 & $\begin{array}{l}\text { Interior } \\
\text { Perimeter }\end{array}$ & $\begin{array}{l}\text { base } \mathrm{RH}+\text { enthalpy econmy } \\
\text { base } \mathrm{DD}+\text { enthalpy economy }+ \\
\text { hot deck reset by } 0 . \mathrm{A} \text {. }\end{array}$ & 7.40 & 4.72 & 3.01 \\
\hline 15 & $\begin{array}{l}\text { Interior } \\
\text { Perimeter }\end{array}$ & $\begin{array}{l}\text { Base VAV + enthalpy economy } \\
\text { Base DD + enthalpy economy + } \\
\text { hot deck reset by } 0 . A \text {. }\end{array}$ & 5.45 & 4.52 & 2.83 \\
\hline 16 & $\begin{array}{l}\text { Interior } \\
\text { Perimeter }\end{array}$ & $\begin{array}{l}\text { base RH + enthalpy economy + } \\
\text { supply air reset by zone demand } \\
\text { base DD + enthalpy economy }+ \\
\text { hot and cold decks reset by } \\
\text { zone demand }\end{array}$ & 6.35 & 4.43 & 3.01 \\
\hline 17 & $\begin{array}{l}\text { Interior } \\
\text { Perimeter }\end{array}$ & $\begin{array}{l}\text { base VAV + enthalpy economy } \\
\text { base DD }+ \text { enthalpy economy }+ \\
\text { hot and cold decks reset by } \\
\text { zone demand }\end{array}$ & 4.43 & 4.24 & 2.83 \\
\hline 18 & $\begin{array}{l}\text { Interior } \\
\text { Perimeter }\end{array}$ & $\begin{array}{l}\text { base } \mathrm{RH}+\text { enthalpy economy }+ \\
\text { supply air reset by zone demand } \\
\text { base VAV + enthalpy economy }\end{array}$ & 3.87 & 3.98 & 1.47 \\
\hline 19 & $\begin{array}{l}\text { Interior } \\
\text { Perimeter }\end{array}$ & $\begin{array}{l}\text { base } \mathrm{RH}+\text { enthalpy economy }+ \\
\text { supply air reset by zone demand } \\
\text { FC }\end{array}$ & 4.36 & 3.81 & 1.55 \\
\hline 20 & $\begin{array}{l}\text { Interior } \\
\text { Perimeter }\end{array}$ & $\begin{array}{l}\text { base VAV + enthalpy economy } \\
\text { FC }\end{array}$ & 2.47 & 3.61 & 1.37 \\
\hline
\end{tabular}


Table 7. Comparative Annual Energy Consumption - Lake Charles, LA

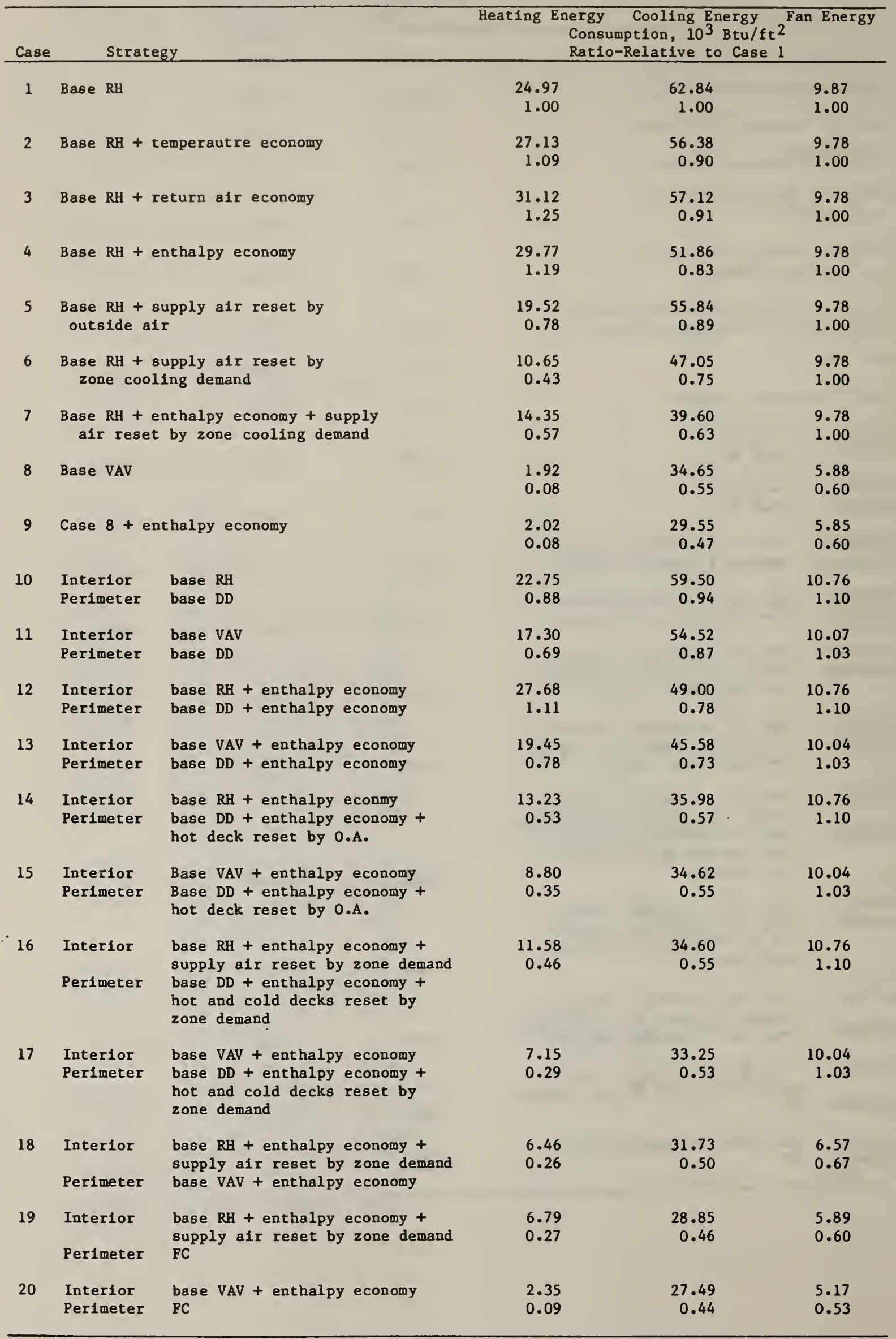


Table 8. Comparative Annual Energy Consumption, Madison, WI

\begin{tabular}{|c|c|c|c|c|c|}
\hline Case & \multicolumn{2}{|c|}{ Strategy } & Heating Enc & $\begin{array}{l}\text { Cooling Ene } \\
\text { pt1on, } 10^{3} \\
\text { Relative to }\end{array}$ & $\begin{array}{l}2^{\text {Fan Energy }} \\
1\end{array}$ \\
\hline 1 & \multicolumn{2}{|l|}{ Base RH } & $\begin{array}{r}39.20 \\
1.00\end{array}$ & $\begin{array}{r}44.02 \\
1.00\end{array}$ & $\begin{array}{r}11.89 \\
1.00\end{array}$ \\
\hline 2 & \multicolumn{2}{|c|}{ Base $\mathrm{RH}+$ temperature economy } & $\begin{array}{r}46.18 \\
1.18\end{array}$ & $\begin{array}{r}26.87 \\
0.61\end{array}$ & $\begin{array}{r}11.89 \\
1.00\end{array}$ \\
\hline 3 & \multicolumn{2}{|c|}{ Base $\mathrm{RH}+$ return air economy } & $\begin{array}{r}48.88 \\
1.28\end{array}$ & $\begin{array}{r}22.70 \\
0.52\end{array}$ & $\begin{array}{r}11.89 \\
1.00\end{array}$ \\
\hline 4 & \multicolumn{2}{|c|}{ Base RH + enthalpy economy } & $\begin{array}{r}48.58 \\
1.24\end{array}$ & $\begin{array}{r}21.90 \\
0.50\end{array}$ & $\begin{array}{r}11.89 \\
1.00\end{array}$ \\
\hline 5 & \multicolumn{2}{|c|}{$\begin{array}{l}\text { Base } \mathrm{RH}+\text { supply a1r reset by } \\
\text { outs1de air }\end{array}$} & $\begin{array}{r}24.43 \\
0.88\end{array}$ & $\begin{array}{r}36.17 \\
0.82\end{array}$ & $\begin{array}{r}11.89 \\
1.00\end{array}$ \\
\hline 6 & \multicolumn{2}{|c|}{$\begin{array}{l}\text { Base RH + supply alr reset by } \\
\text { zone coollng demand }\end{array}$} & $\begin{array}{r}24.05 \\
0.61\end{array}$ & $\begin{array}{r}28.39 \\
0.64\end{array}$ & $\begin{array}{r}11.89 \\
1.00\end{array}$ \\
\hline 7 & \multicolumn{2}{|c|}{$\begin{array}{l}\text { Base } \mathrm{RH}+\text { enthalpy economy + supply } \\
\text { a1r reset by zone cooling demand }\end{array}$} & $\begin{array}{r}33.33 \\
0.85\end{array}$ & $\begin{array}{r}16.03 \\
0.36\end{array}$ & $\begin{array}{r}11.89 \\
1.00\end{array}$ \\
\hline 8 & \multicolumn{2}{|l|}{ Base VAV } & $\begin{array}{r}16.95 \\
0.43\end{array}$ & $\begin{array}{r}17.97 \\
0.41\end{array}$ & $\begin{array}{l}6.39 \\
0.54\end{array}$ \\
\hline 9 & \multicolumn{2}{|c|}{ Case $8+$ enthalpy economy } & $\begin{array}{r}17.03 \\
0.43\end{array}$ & $\begin{array}{r}11.77 \\
0.27\end{array}$ & $\begin{array}{l}6.34 \\
0.53\end{array}$ \\
\hline 10 & $\begin{array}{l}\text { Interior } \\
\text { Perimeter }\end{array}$ & $\begin{array}{l}\text { base } \mathrm{RH} \\
\text { base } \mathrm{DD}\end{array}$ & $\begin{array}{r}38.71 \\
0.99\end{array}$ & $\begin{array}{r}42.80 \\
0.97\end{array}$ & $\begin{array}{r}13.11 \\
1.10\end{array}$ \\
\hline 11 & $\begin{array}{l}\text { Interior } \\
\text { Perimeter }\end{array}$ & $\begin{array}{l}\text { base VAV } \\
\text { base DD }\end{array}$ & $\begin{array}{r}33.58 \\
0.86\end{array}$ & $\begin{array}{r}38.20 \\
0.87\end{array}$ & $\begin{array}{r}12.38 \\
1.04\end{array}$ \\
\hline 12 & $\begin{array}{l}\text { Interior } \\
\text { Perimeter }\end{array}$ & $\begin{array}{l}\text { base RH + enthalpy economy } \\
\text { base DD + enthalpy economy }\end{array}$ & $\begin{array}{r}51.21 \\
1.31\end{array}$ & $\begin{array}{r}20.77 \\
0.47\end{array}$ & $\begin{array}{r}13.11 \\
1.10\end{array}$ \\
\hline 13 & $\begin{array}{l}\text { Interior } \\
\text { Perimeter }\end{array}$ & $\begin{array}{l}\text { base VAV + enthalpy economy } \\
\text { base DD + enthalpy economy }\end{array}$ & $\begin{array}{r}39.71 \\
1.01\end{array}$ & $\begin{array}{r}19.37 \\
0.44\end{array}$ & $\begin{array}{r}12.33 \\
1.04\end{array}$ \\
\hline 14 & $\begin{array}{l}\text { Inter1or } \\
\text { Perimeter }\end{array}$ & $\begin{array}{l}\text { base } \mathrm{RH}+\text { enthalpy econmy } \\
\text { base } \mathrm{DD}+\text { enthalpy economy + } \\
\text { hot deck reset by } 0 . \mathrm{A} \text {. }\end{array}$ & $\begin{array}{r}42.67 \\
1.09\end{array}$ & $\begin{array}{r}14.13 \\
0.32\end{array}$ & $\begin{array}{r}13.11 \\
1.10\end{array}$ \\
\hline 15 & $\begin{array}{l}\text { Interior } \\
\text { Per1meter }\end{array}$ & $\begin{array}{l}\text { Base VAV + enthalpy economy } \\
\text { Base DD + enthalpy economy }+ \\
\text { hot deck reset by } 0 . A \text {. }\end{array}$ & $\begin{array}{r}33.27 \\
0.58\end{array}$ & $\begin{array}{r}13.50 \\
0.31\end{array}$ & $\begin{array}{r}12.33 \\
1.04\end{array}$ \\
\hline .16 & $\begin{array}{l}\text { Interfor } \\
\text { Per1meter }\end{array}$ & $\begin{array}{l}\text { base RH + enthalpy economy }+ \\
\text { supply a1r reset by zone demand } \\
\text { base DD + enthalpy economy }+ \\
\text { hot and cold decks reset by } \\
\text { zone demand }\end{array}$ & $\begin{array}{r}37.69 \\
0.96\end{array}$ & $\begin{array}{r}13.10 \\
0.30\end{array}$ & $\begin{array}{r}13.13 \\
1.10\end{array}$ \\
\hline 17 & $\begin{array}{l}\text { Interior } \\
\text { Per1meter }\end{array}$ & $\begin{array}{l}\text { base VAV + enthalpy economy } \\
\text { base DD + enthalpy economy }+ \\
\text { hot and cold decks reset by } \\
\text { zone demand }\end{array}$ & $\begin{array}{r}28.17 \\
0.72\end{array}$ & $\begin{array}{r}12.48 \\
0.28\end{array}$ & $\begin{array}{r}12.33 \\
1.04\end{array}$ \\
\hline 18 & $\begin{array}{l}\text { Inter1or } \\
\text { Perimeter }\end{array}$ & $\begin{array}{l}\text { base } \mathrm{RH}+\text { enthalpy economy }+ \\
\text { supply afr reset by zone demand } \\
\text { base VAV + enthalpy economy }\end{array}$ & $\begin{array}{r}27.18 \\
0.69\end{array}$ & $\begin{array}{r}12.39 \\
0.28\end{array}$ & $\begin{array}{l}7.12 \\
0.60\end{array}$ \\
\hline 19 & $\begin{array}{l}\text { Interior } \\
\text { Perimeter }\end{array}$ & $\begin{array}{l}\text { base RH + enthalpy economy }+ \\
\text { supply air reset by zone demand } \\
\text { FC }\end{array}$ & $\begin{array}{r}29.28 \\
0.75\end{array}$ & $\begin{array}{r}11.57 \\
0.26\end{array}$ & $\begin{array}{l}6.69 \\
0.56\end{array}$ \\
\hline 20 & $\begin{array}{l}\text { Interior } \\
\text { Perimeter }\end{array}$ & $\begin{array}{l}\text { base VAV + enthalpy economy } \\
\text { FC }\end{array}$ & $\begin{array}{r}19.13 \\
0.49\end{array}$ & $\begin{array}{r}10.95 \\
0.25\end{array}$ & $\begin{array}{l}5.91 \\
0.50\end{array}$ \\
\hline
\end{tabular}


Table 9. Comparative Annual Energy Consumption - Nashville, TN B

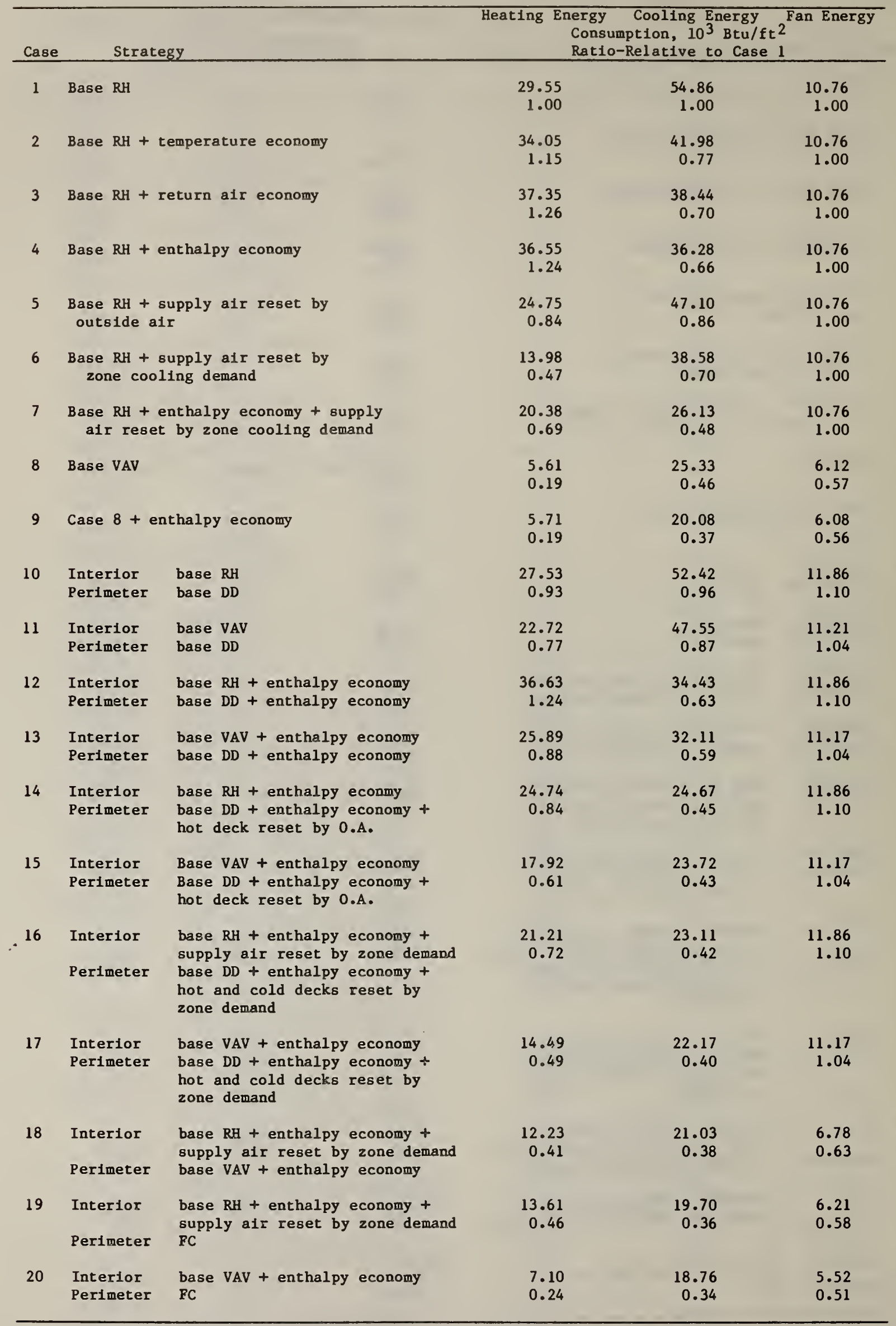


Table 10. Comparative Annual Energy Consumption - Santa Maria, CA

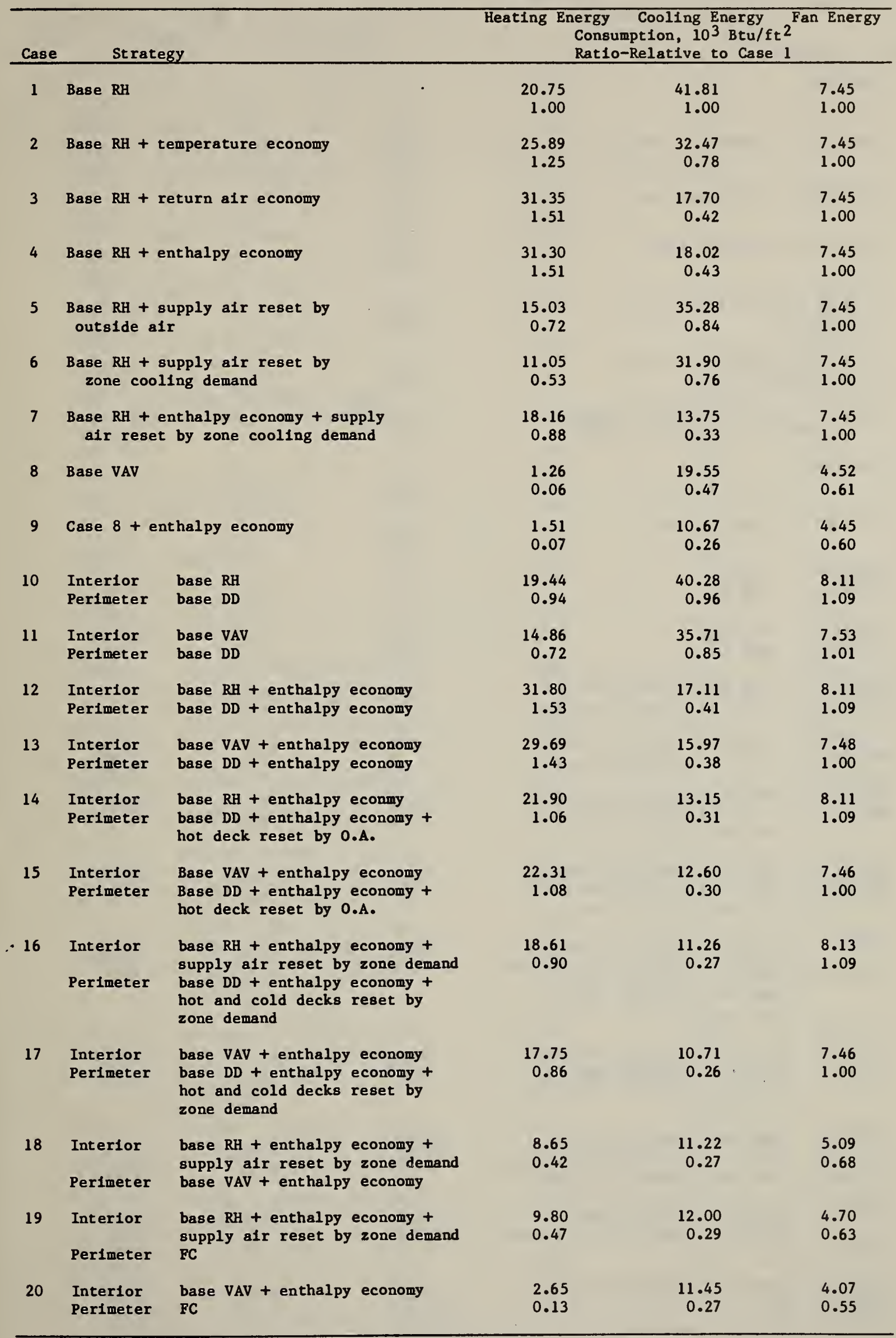


Table 11. Comparative Annual Energy Consumption - Seattle, VA

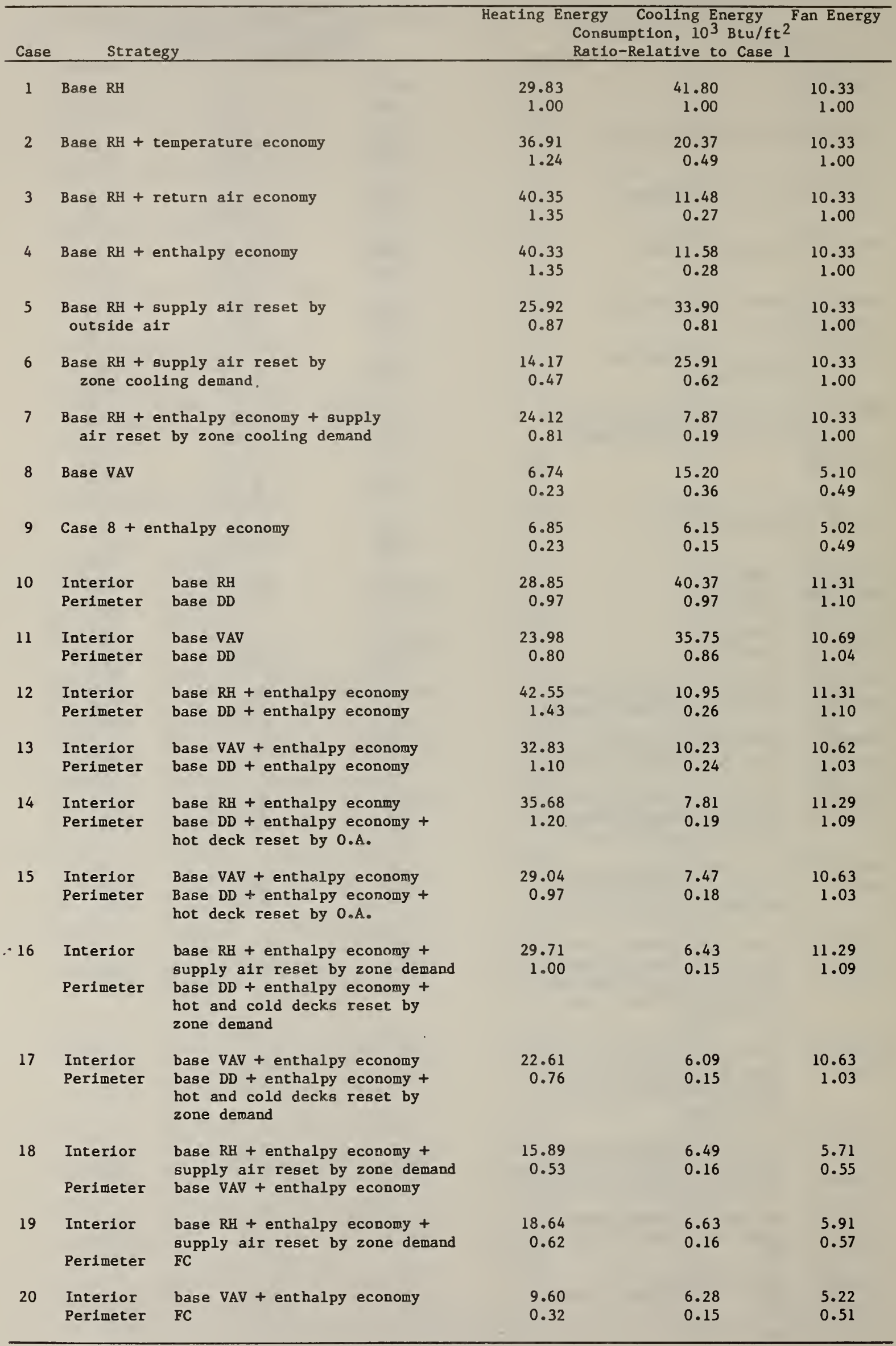


Table 12. Comparative Annual Energy Consumption - Washington, D.C.

\begin{tabular}{|c|c|c|c|c|c|}
\hline Case & \multicolumn{2}{|c|}{ Strategy } & Heating En & $\begin{array}{l}\text { IIng Ene } \\
n, 10^{3} \\
\text { tive to }\end{array}$ & Fan Energy \\
\hline 1 & \multicolumn{2}{|l|}{ Base RH } & $\begin{array}{r}32.51 \\
1.00\end{array}$ & $\begin{array}{r}51.20 \\
1.00\end{array}$ & $\begin{array}{r}11.42 \\
1.00\end{array}$ \\
\hline 2 & \multicolumn{2}{|c|}{ Base RH + temperature economy } & $\begin{array}{r}37.70 \\
1.16\end{array}$ & $\begin{array}{r}34.89 \\
0.68\end{array}$ & $\begin{array}{r}11.42 \\
1.00\end{array}$ \\
\hline 3 & \multicolumn{2}{|c|}{ Base $\mathrm{RH}+$ return aIr economy } & $\begin{array}{r}40.90 \\
1.26\end{array}$ & $\begin{array}{r}31.43 \\
0.61\end{array}$ & $\begin{array}{r}11.42 \\
1.00\end{array}$ \\
\hline 4 & \multicolumn{2}{|c|}{ Base RH + enthalpy economy } & $\begin{array}{r}40.34 \\
1.24\end{array}$ & $\begin{array}{r}29.81 \\
0.58\end{array}$ & $\begin{array}{r}11.42 \\
1.00\end{array}$ \\
\hline 5 & \multicolumn{2}{|c|}{$\begin{array}{l}\text { Base } \mathrm{RH}+\text { supply afr reset by } \\
\text { outside alr }\end{array}$} & $\begin{array}{r}28.15 \\
0.87\end{array}$ & $\begin{array}{r}43.22 \\
0.84\end{array}$ & $\begin{array}{r}11.42 \\
1.00\end{array}$ \\
\hline 6 & \multicolumn{2}{|c|}{$\begin{array}{l}\text { Base } \mathrm{RH}+\text { supply air reset by } \\
\text { zone coollng demand }\end{array}$} & $\begin{array}{r}16.58 \\
0.51\end{array}$ & $\begin{array}{r}34.52 \\
0.67\end{array}$ & $\begin{array}{r}11.42 \\
1.00\end{array}$ \\
\hline 7 & \multicolumn{2}{|c|}{$\begin{array}{l}\text { Base } \mathrm{RH}+\text { enthalpy economy + supply } \\
\text { alr reset by zone cooling demand }\end{array}$} & $\begin{array}{r}24.60 \\
0.76\end{array}$ & $\begin{array}{r}21.81 \\
0.43\end{array}$ & $\begin{array}{r}11.42 \\
1.00\end{array}$ \\
\hline 8 & \multicolumn{2}{|l|}{ Base VAV } & $\begin{array}{l}8.20 \\
0.25\end{array}$ & $\begin{array}{r}21.62 \\
0.42\end{array}$ & $\begin{array}{l}5.45 \\
0.48\end{array}$ \\
\hline 9 & \multicolumn{2}{|c|}{ Case $8+$ enthalpy economy } & $\begin{array}{l}8.28 \\
0.25\end{array}$ & $\begin{array}{r}15.76 \\
0.31\end{array}$ & $\begin{array}{l}5.40 \\
0.47\end{array}$ \\
\hline 10 & $\begin{array}{l}\text { Interior } \\
\text { Perimeter }\end{array}$ & $\begin{array}{l}\text { base } \mathrm{RH} \\
\text { base } \mathrm{DD}\end{array}$ & $\begin{array}{r}30.65 \\
0.94\end{array}$ & $\begin{array}{r}48.95 \\
0.96\end{array}$ & $\begin{array}{r}12.53 \\
1.10\end{array}$ \\
\hline 11 & $\begin{array}{l}\text { Interior } \\
\text { Perimeter }\end{array}$ & $\begin{array}{l}\text { base VAV } \\
\text { base DD }\end{array}$ & $\begin{array}{r}25.70 \\
0.79\end{array}$ & $\begin{array}{r}44.14 \\
0.86\end{array}$ & $\begin{array}{r}11.85 \\
1.04\end{array}$ \\
\hline 12 & $\begin{array}{l}\text { Interior } \\
\text { Perimeter }\end{array}$ & $\begin{array}{l}\text { base } \mathrm{RH}+\text { enthalpy economy } \\
\text { base } \mathrm{DD}+\text { enthalpy economy }\end{array}$ & $\begin{array}{r}40.98 \\
1.26\end{array}$ & $\begin{array}{r}28.03 \\
0.55\end{array}$ & $\begin{array}{r}12.53 \\
1.10\end{array}$ \\
\hline 13 & $\begin{array}{l}\text { Interior } \\
\text { Perimeter }\end{array}$ & $\begin{array}{l}\text { base VAV + enthalpy economy } \\
\text { base DD + enthalpy economy }\end{array}$ & $\begin{array}{r}29.80 \\
0.92\end{array}$ & $\begin{array}{r}26.08 \\
0.51\end{array}$ & $\begin{array}{r}11.81 \\
1.03\end{array}$ \\
\hline 14 & $\begin{array}{l}\text { Interior } \\
\text { Perimeter }\end{array}$ & $\begin{array}{l}\text { base } \mathrm{RH}+\text { enthalpy econmy } \\
\text { base } \mathrm{DD}+\text { enthalpy economy + } \\
\text { hot deck reset by } \mathrm{O.A} \text {. }\end{array}$ & $\begin{array}{r}30.81 \\
0.95\end{array}$ & $\begin{array}{r}19.66 \\
0.38\end{array}$ & $\begin{array}{r}12.54 \\
1.10\end{array}$ \\
\hline 15 & $\begin{array}{l}\text { Interior } \\
\text { Perimeter }\end{array}$ & $\begin{array}{l}\text { Base VAV + enthalpy economy } \\
\text { Base DD + enthalpy economy + } \\
\text { hot deck reset by } 0 . A \text {. }\end{array}$ & $\begin{array}{r}22.73 \\
0.70\end{array}$ & $\begin{array}{r}18.85 \\
0.37\end{array}$ & $\begin{array}{r}11.79 \\
1.03\end{array}$ \\
\hline 16 & $\begin{array}{l}\text { Interior } \\
\text { Perimeter }\end{array}$ & $\begin{array}{l}\text { base RH + enthalpy economy + } \\
\text { supply alr reset by zone demsnd } \\
\text { base DD + enthalpy economy + } \\
\text { hot and cold decks reset by } \\
\text { zone demsind }\end{array}$ & $\begin{array}{r}26.45 \\
0.81\end{array}$ & $\begin{array}{r}18.47 \\
0.36\end{array}$ & $\begin{array}{r}12.54 \\
1.10\end{array}$ \\
\hline 17 & $\begin{array}{l}\text { Interior } \\
\text { Perimeter }\end{array}$ & $\begin{array}{l}\text { base VAV + enthalpy economy } \\
\text { base } \mathrm{DD}+\text { enthalpy economy }+ \\
\text { hot and cold decks reset by } \\
\text { zone demand }\end{array}$ & $\begin{array}{r}118.48 \\
0.57\end{array}$ & $\begin{array}{r}17.66 \\
0.34\end{array}$ & $\begin{array}{r}11.79 \\
1.03\end{array}$ \\
\hline 18 & $\begin{array}{l}\text { Interior } \\
\text { Perimeter }\end{array}$ & $\begin{array}{l}\text { base } \mathrm{RH}+\text { enthalpy economy + } \\
\text { supply alr reset by zone demand } \\
\text { base VAV + enthalpy economy }\end{array}$ & $\begin{array}{r}16.14 \\
0.50\end{array}$ & $\begin{array}{r}16.57 \\
0.32\end{array}$ & $\begin{array}{l}6.12 \\
0.54\end{array}$ \\
\hline 19 & $\begin{array}{l}\text { Interior } \\
\text { Perimeter }\end{array}$ & $\begin{array}{l}\text { base } \mathrm{RH}+\text { enthalpy economy }+ \\
\text { supply alr reset by zone demand } \\
\text { FC }\end{array}$ & $\begin{array}{r}18.15 \\
0.56\end{array}$ & $\begin{array}{r}15.87 \\
0.31\end{array}$ & $\begin{array}{l}6.44 \\
0.56\end{array}$ \\
\hline 20 & $\begin{array}{l}\text { Interior } \\
\text { Perimeter }\end{array}$ & $\begin{array}{l}\text { base VAV + enthalpy economy } \\
\text { FC }\end{array}$ & $\begin{array}{r}10.28 \\
0.32\end{array}$ & $\begin{array}{r}15.06 \\
0.29\end{array}$ & $\begin{array}{l}5.72 \\
0.50\end{array}$ \\
\hline
\end{tabular}




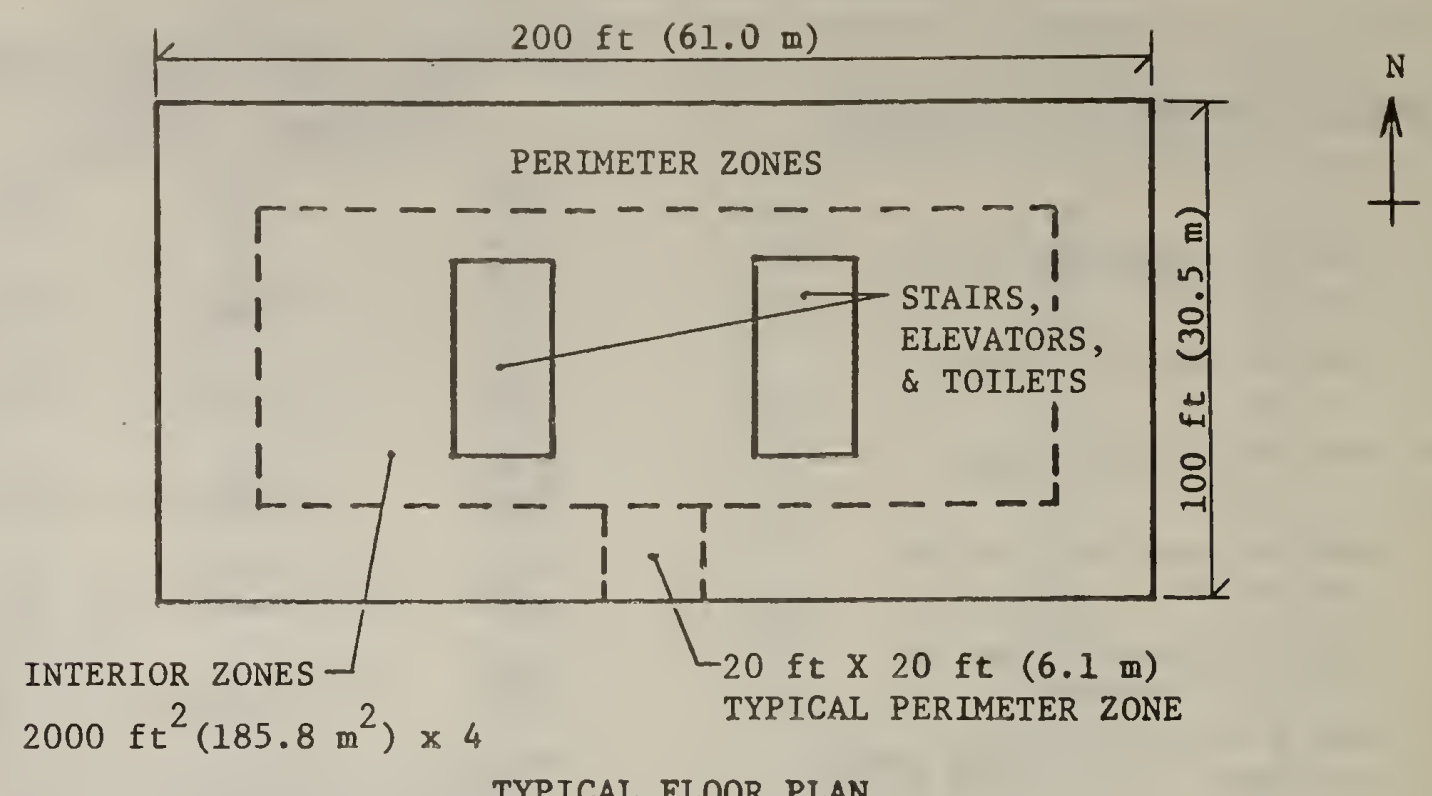

Exterior wall:

spandrel glass, $2^{\prime \prime}(0.05 \mathrm{~m})$ insulation $\mathrm{K}=0.033 \mathrm{Btu} / \mathrm{h} \cdot \mathrm{ft} \cdot{ }^{\circ} \mathrm{F}$ $\left(0.057 \mathrm{~W} / \mathrm{m}^{\circ}{ }^{\circ} \mathrm{K}\right)$, and $1 / 2^{\prime \prime}(0.013 \mathrm{~m})$ gypsum board.

Roof :

built-up roof, $2^{\prime \prime}(0.05 \mathrm{~m})$ insulation $\mathrm{K}=0.033 \mathrm{Btu} / \mathrm{h} \cdot \mathrm{ft} \cdot{ }^{\circ} \mathrm{F}$ $\left(0.057 \mathrm{~W} / \mathrm{m} \cdot{ }^{\circ} \mathrm{K}\right), 31 / 2^{\prime \prime}(0.09 \mathrm{~m})$ lightweight concrete, metal deck, air space, and $3 / 4^{\prime \prime}(0.019 \mathrm{~m})$ ceiling panels.

Typical floor:

$31 / 2^{\prime \prime}(0.09 \mathrm{~m})$ concrete, air space, $3 / 4^{\prime \prime}(0.019 \mathrm{~m})$ ceiling panels, and carpet. $13^{\prime}(3.96 \mathrm{~m})$ floor to floor.

Partition:

$1 / 2^{\prime \prime}(0.013 \mathrm{~m})$ gypsum board, air space, $1 / 2^{\prime \prime}(0.013 \mathrm{~m})$ gypsum board.

Window:

single pane bronze plate, transmittance 0.24 . light color venetian blind.

Figure 1. Large office building model 


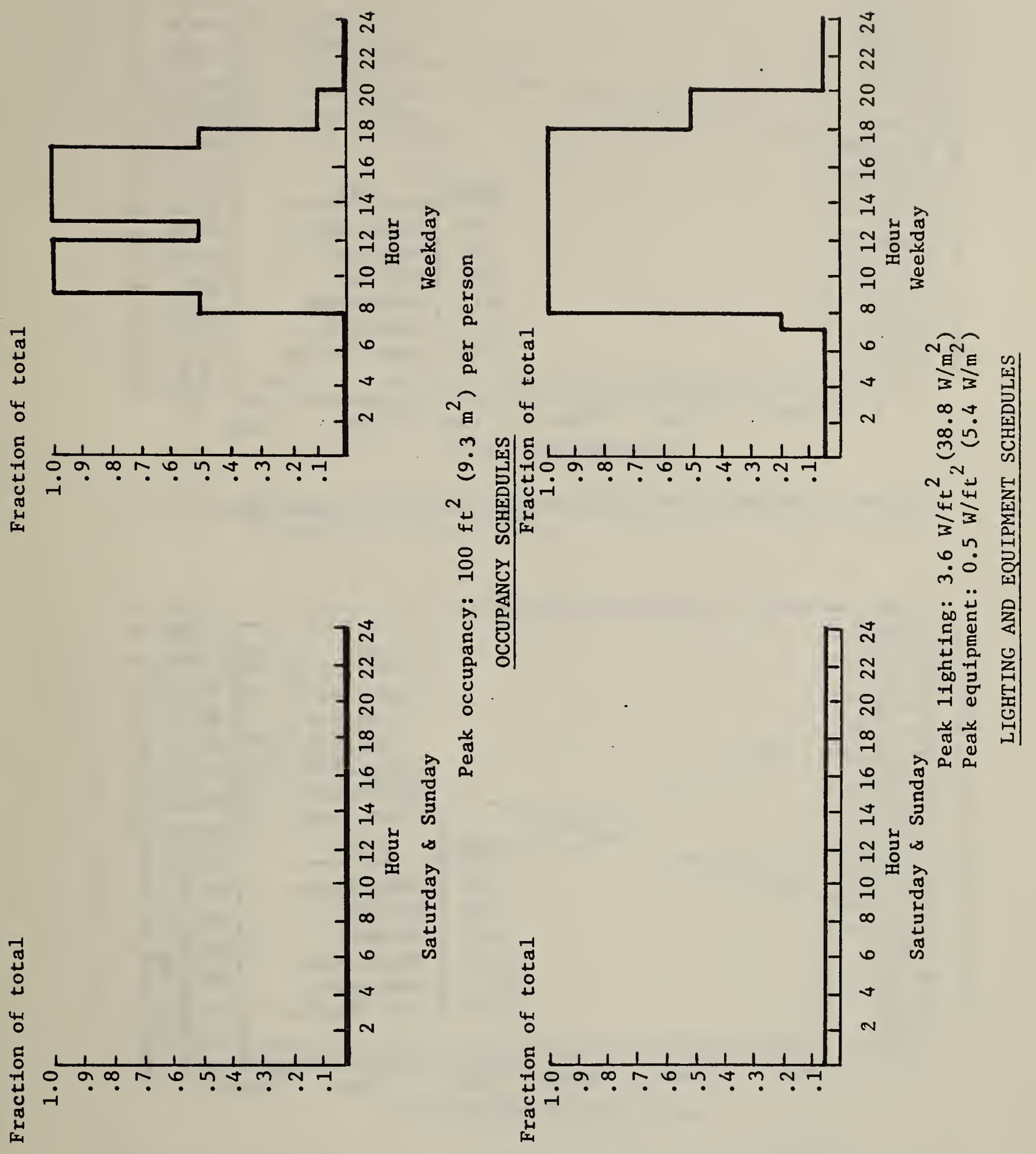

Figure 2. Internal load profiles 


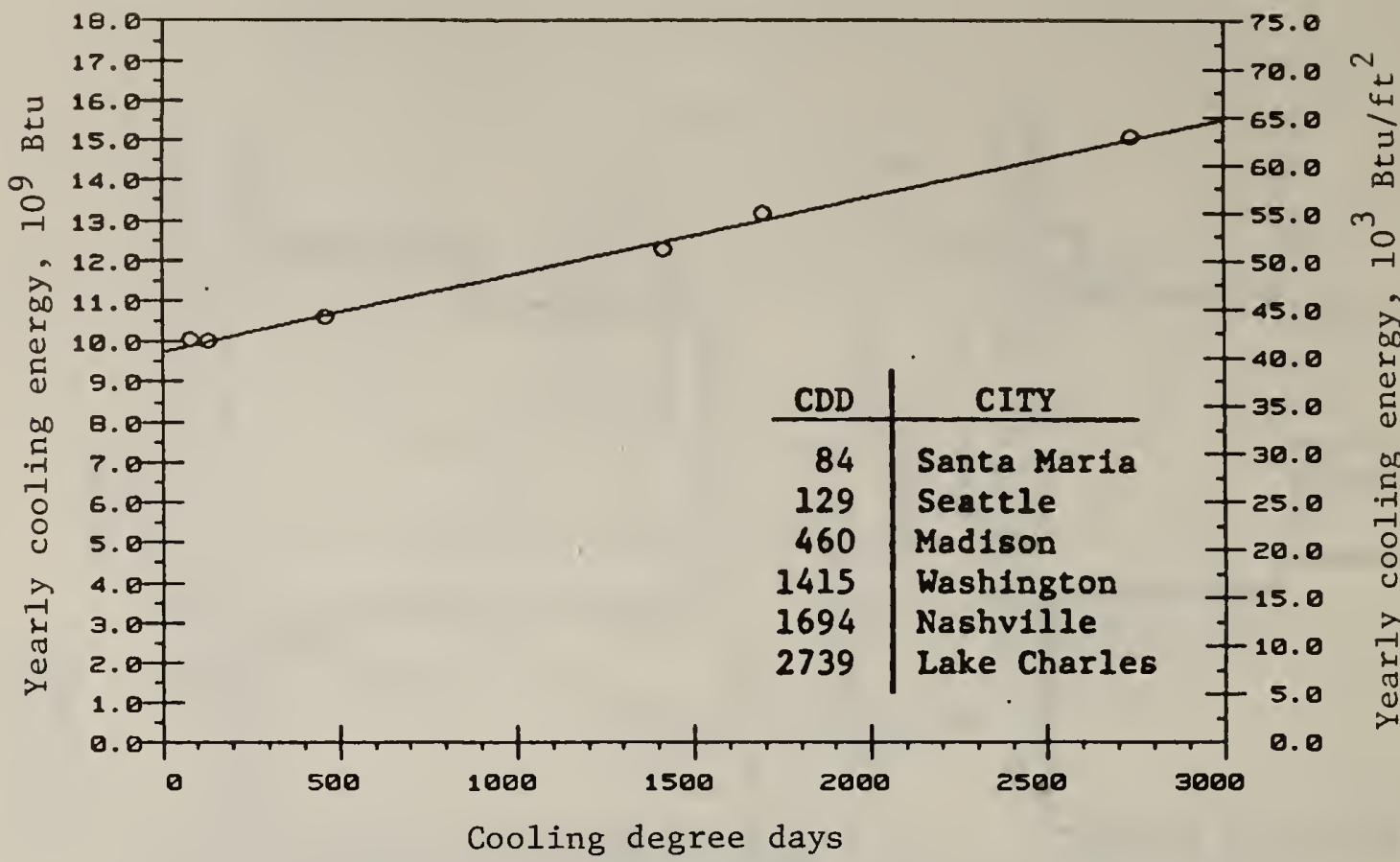

Figure 3. Cooling energy consumption of case 1--base reheat

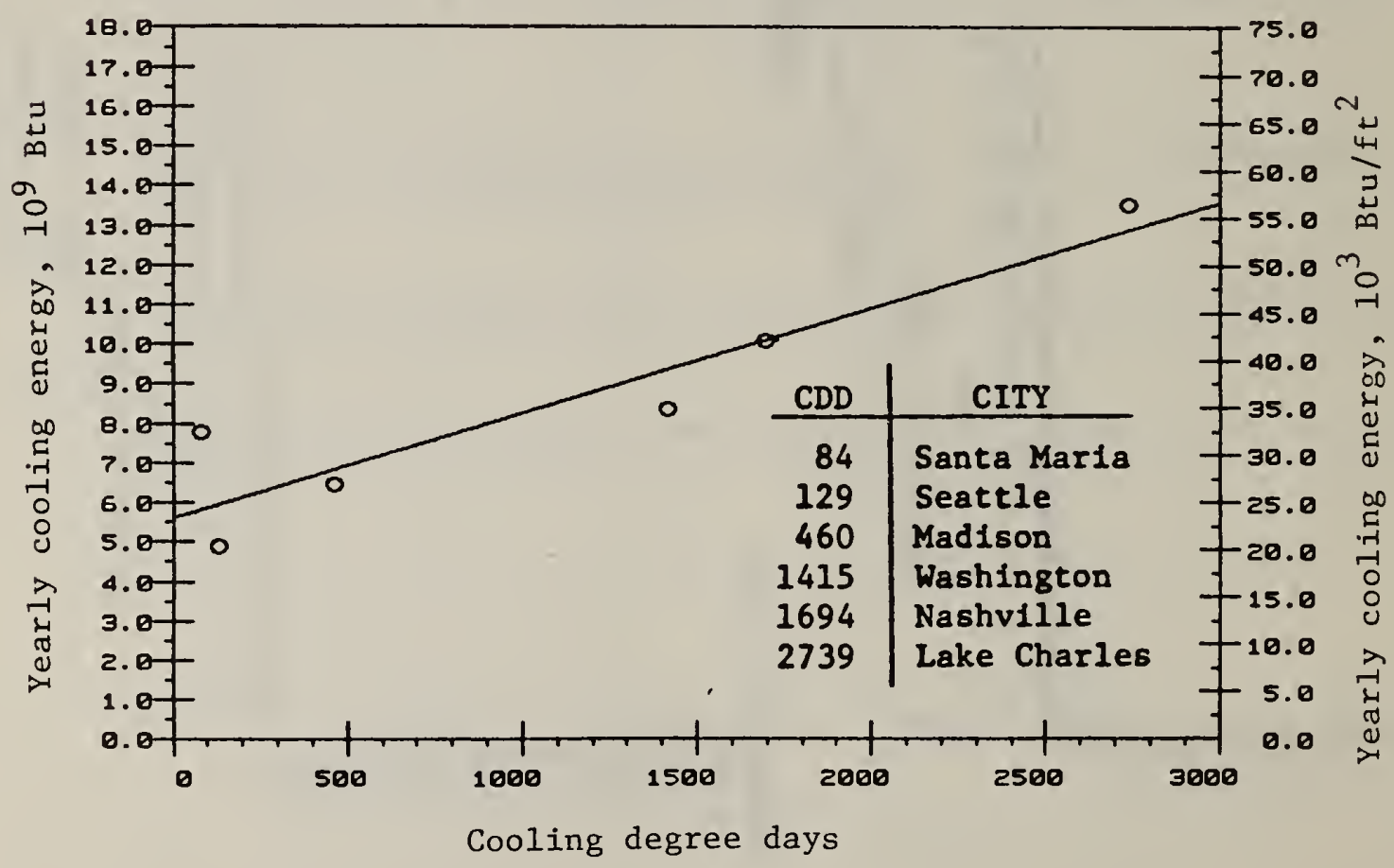

Figure 4. Cooling energy consumption of case 2--base reheat with temperature economy cycle 


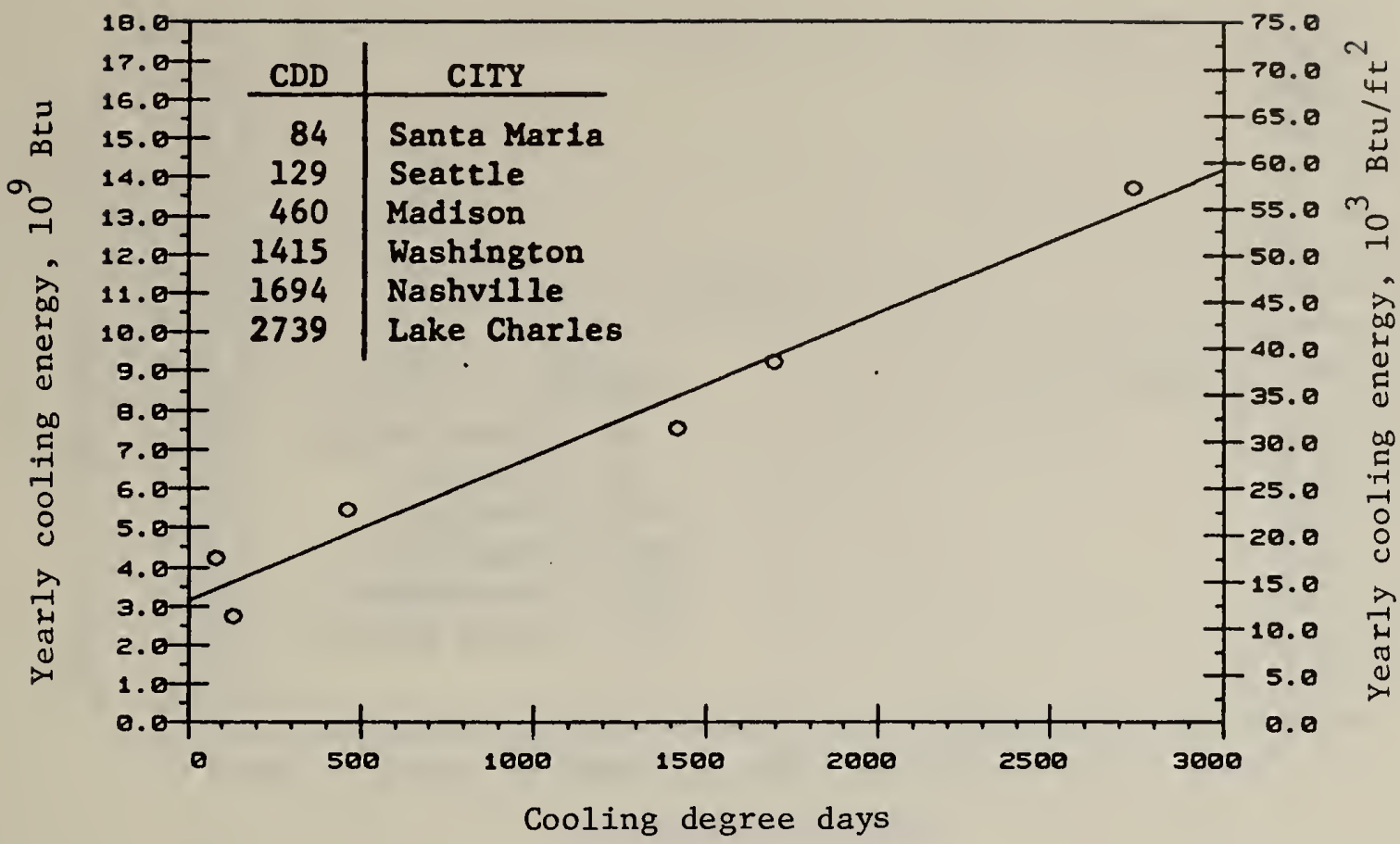

Figure 5. Cooling energy consumption of case 3--base reheat with temperature economy cycle

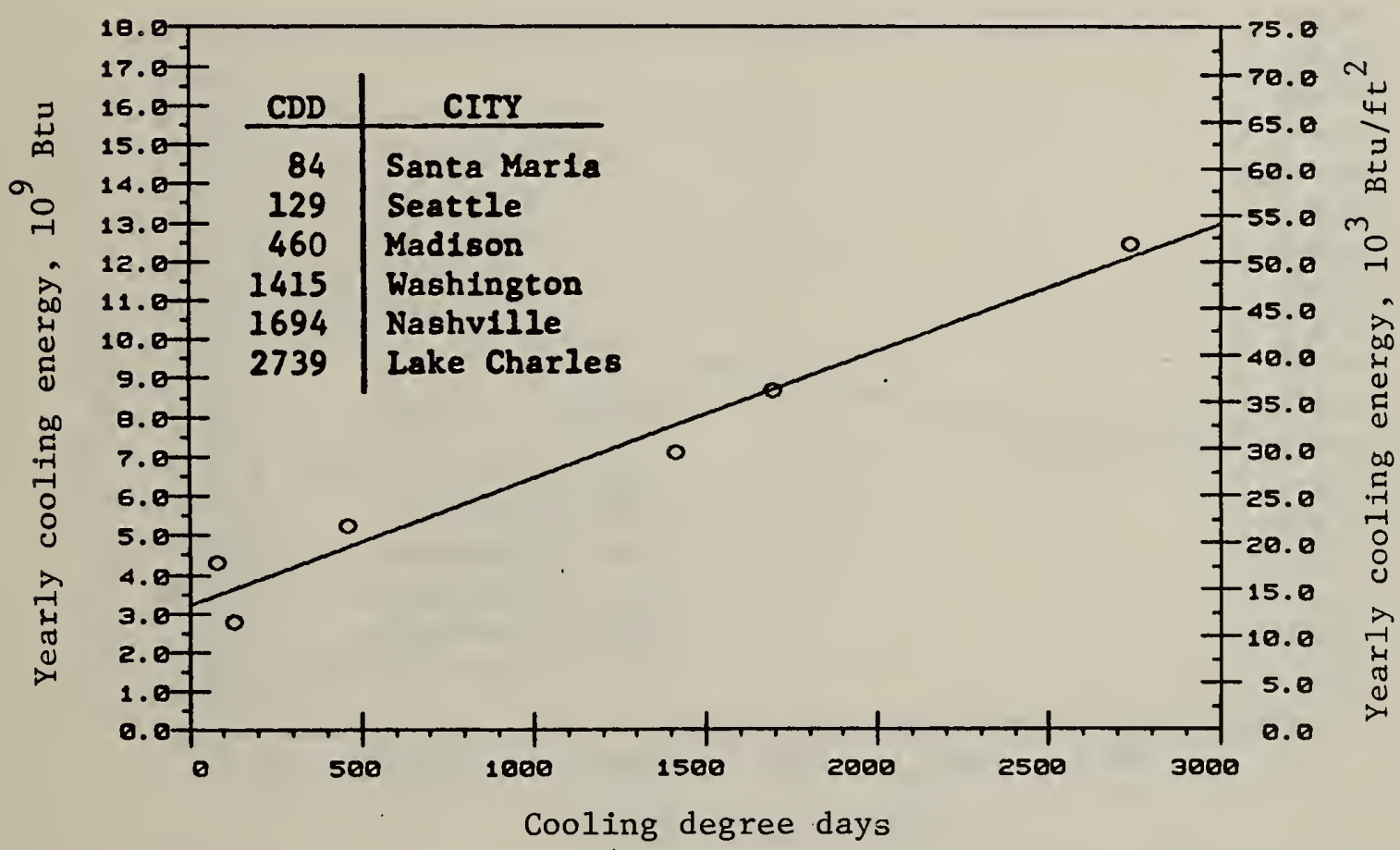

Figure 6. Cooling energy consumption of case 4--base reheat with enthalpy economy cycle 


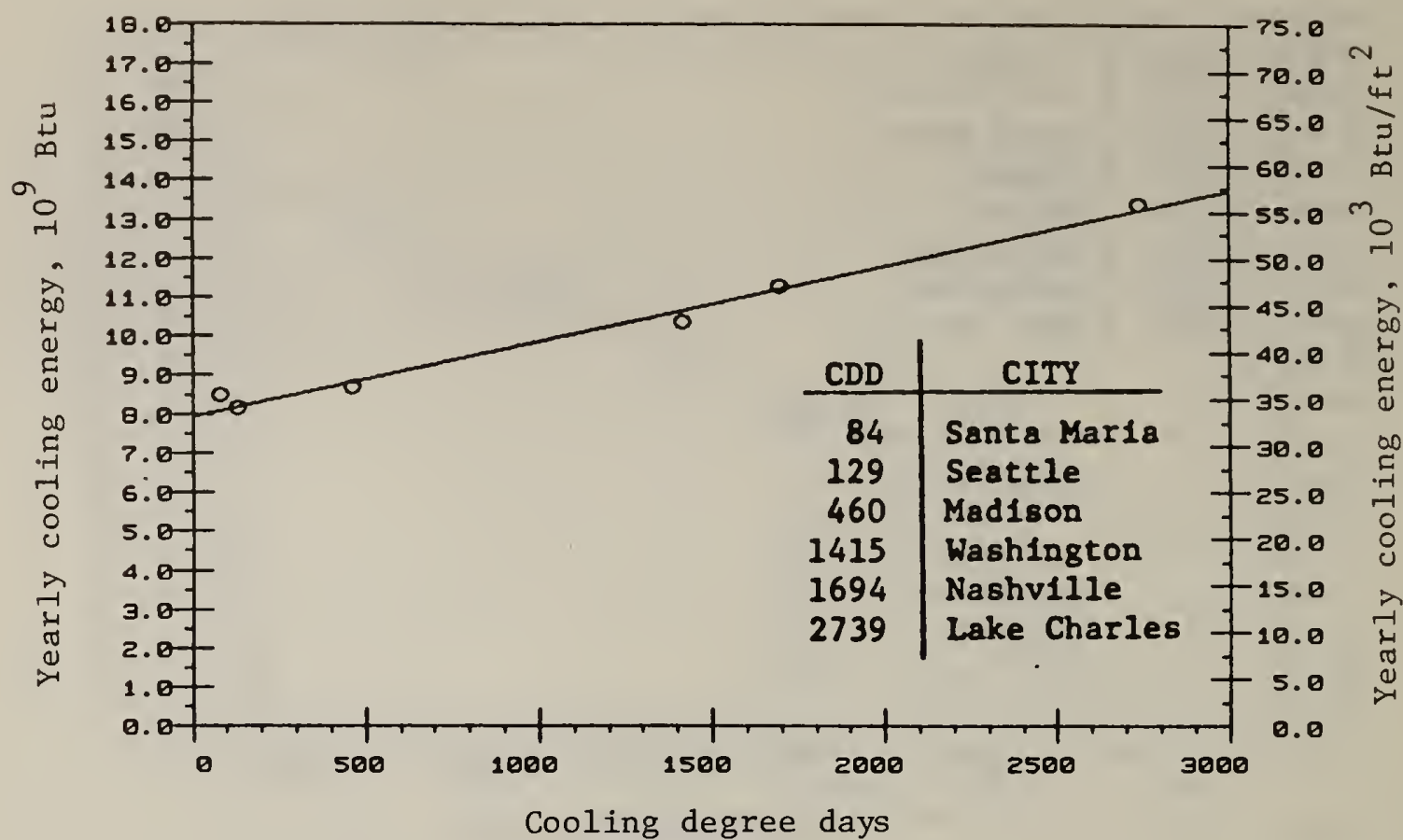

Figure 7. Cooling energy consumption of case 5--base reheat with supply air reset by outside air

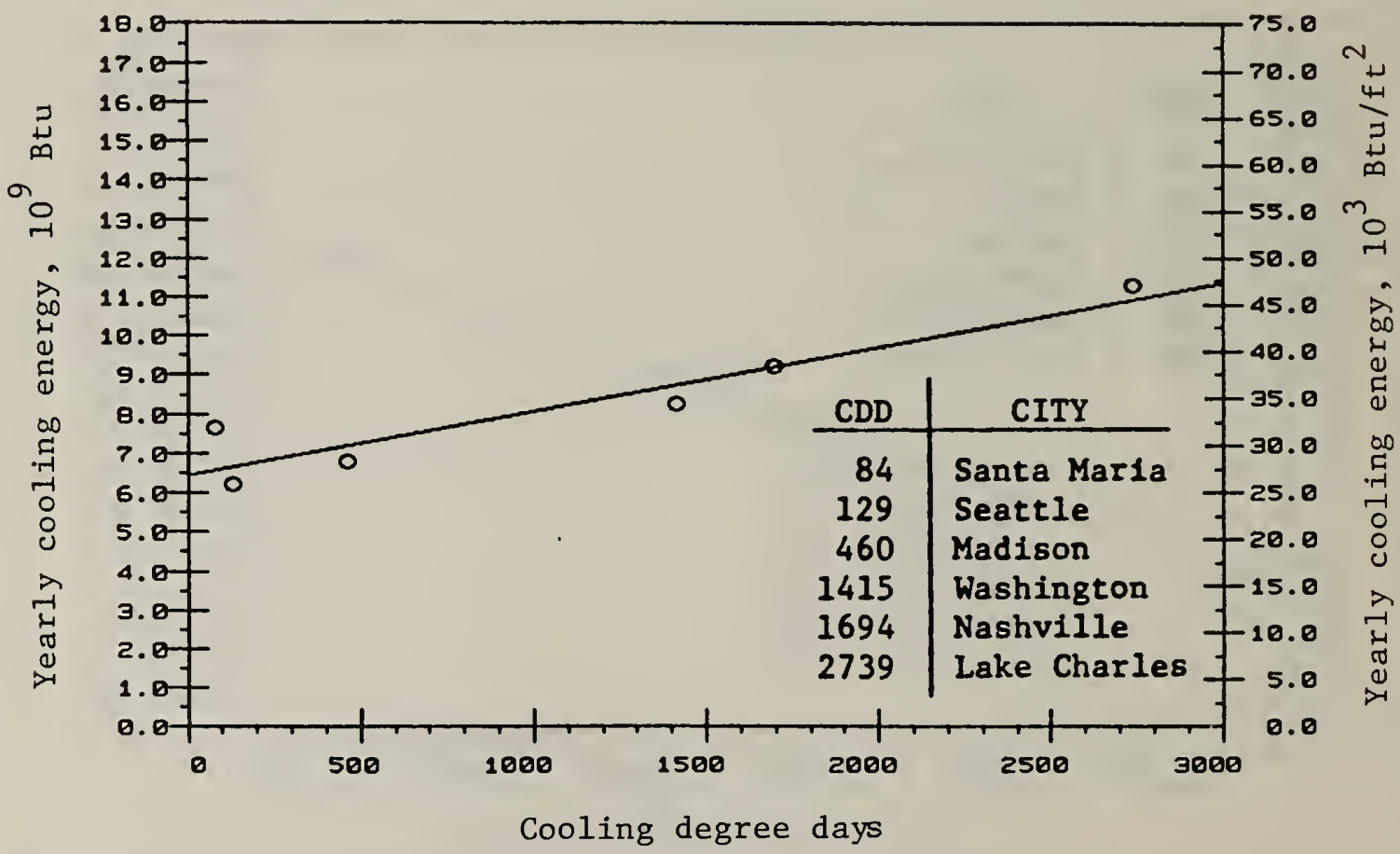

Figure 8. Cooling energy consumption of case 6--base reheat with supply air reset by zone load demand 


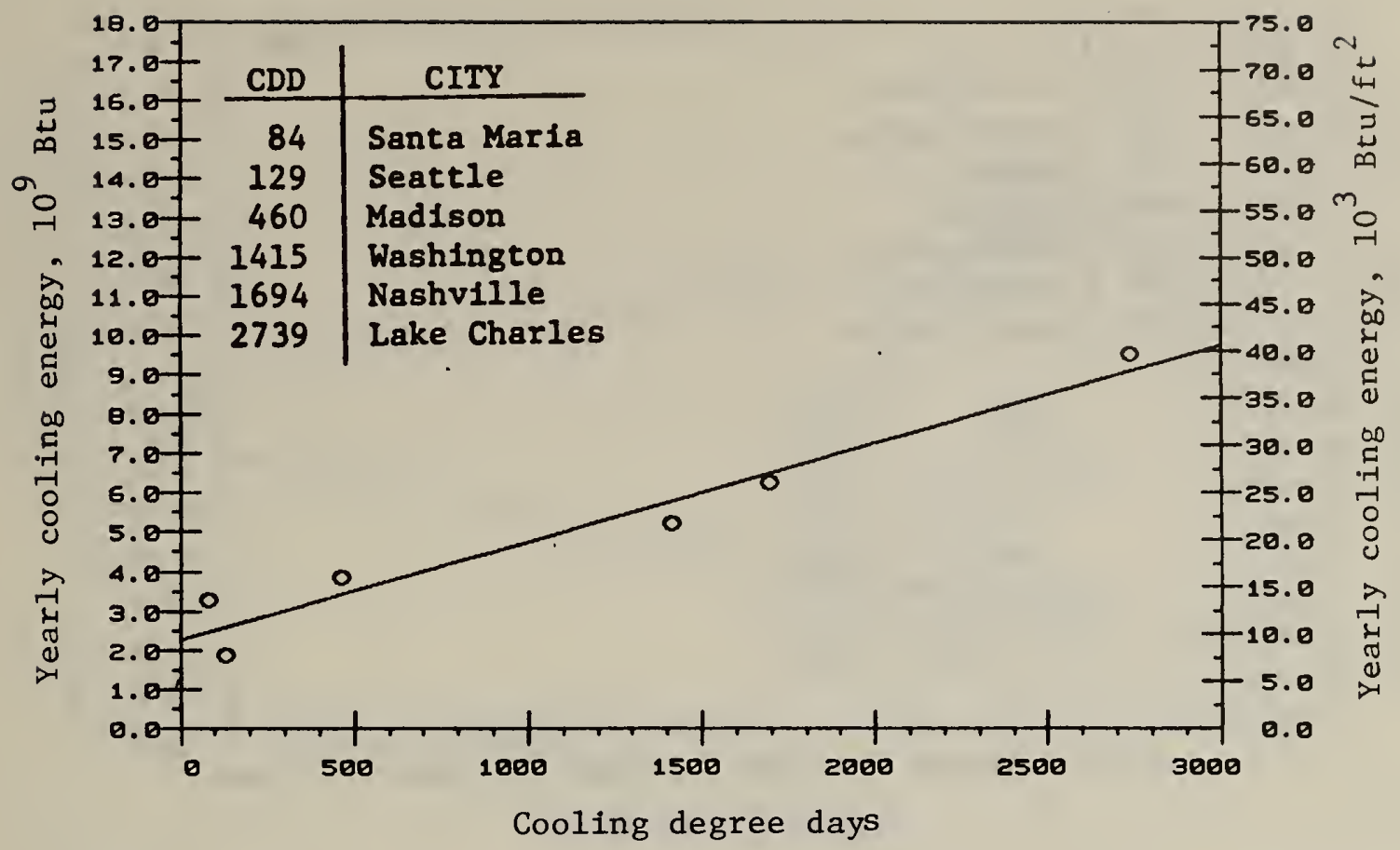

Figure 9. Cooling energy consumption of case 7--base reheat with enthalpy economy cycle and supply air reset by zone load demand

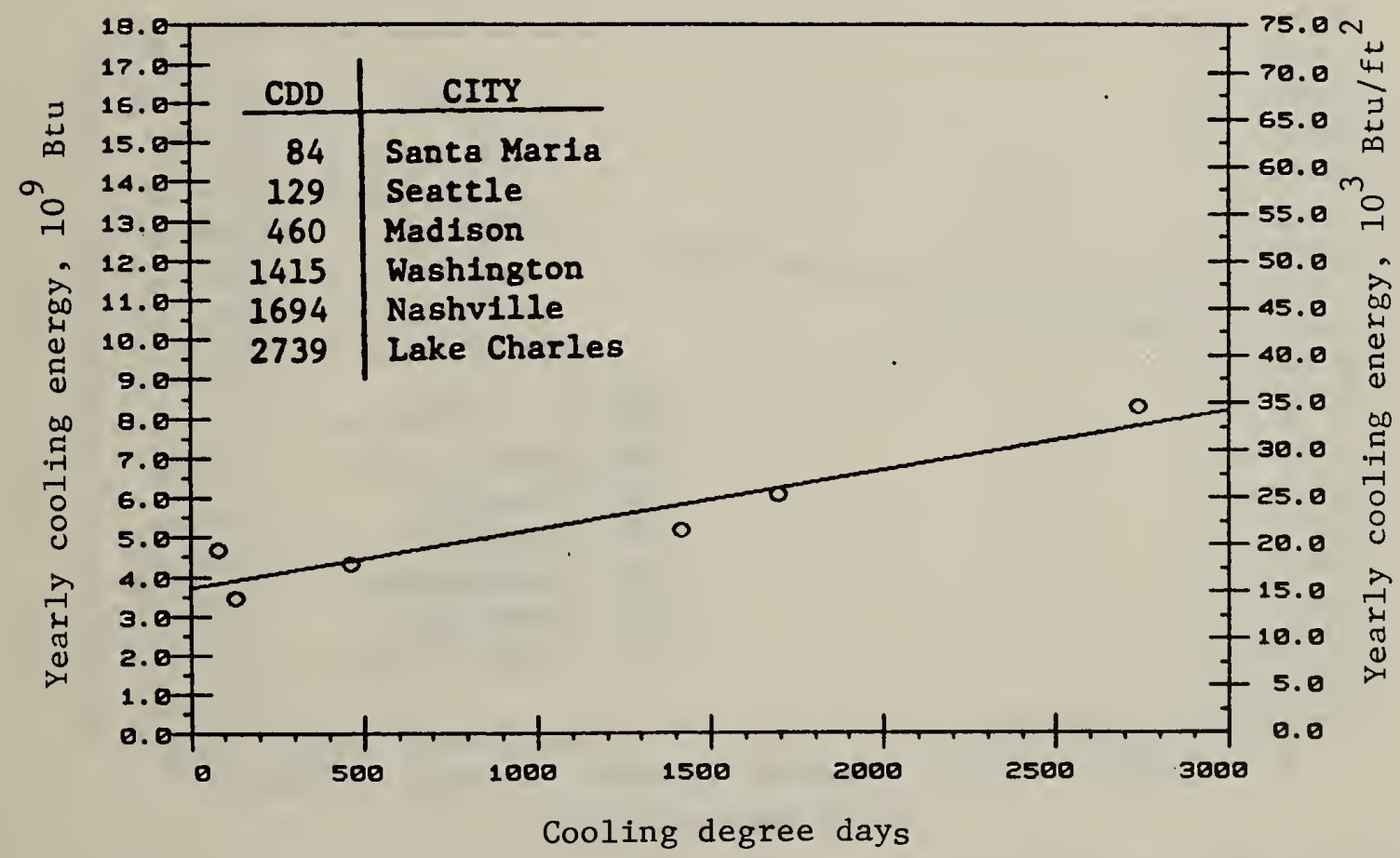

Figure 10. Cooling energy consumption of case 8--base VAV 


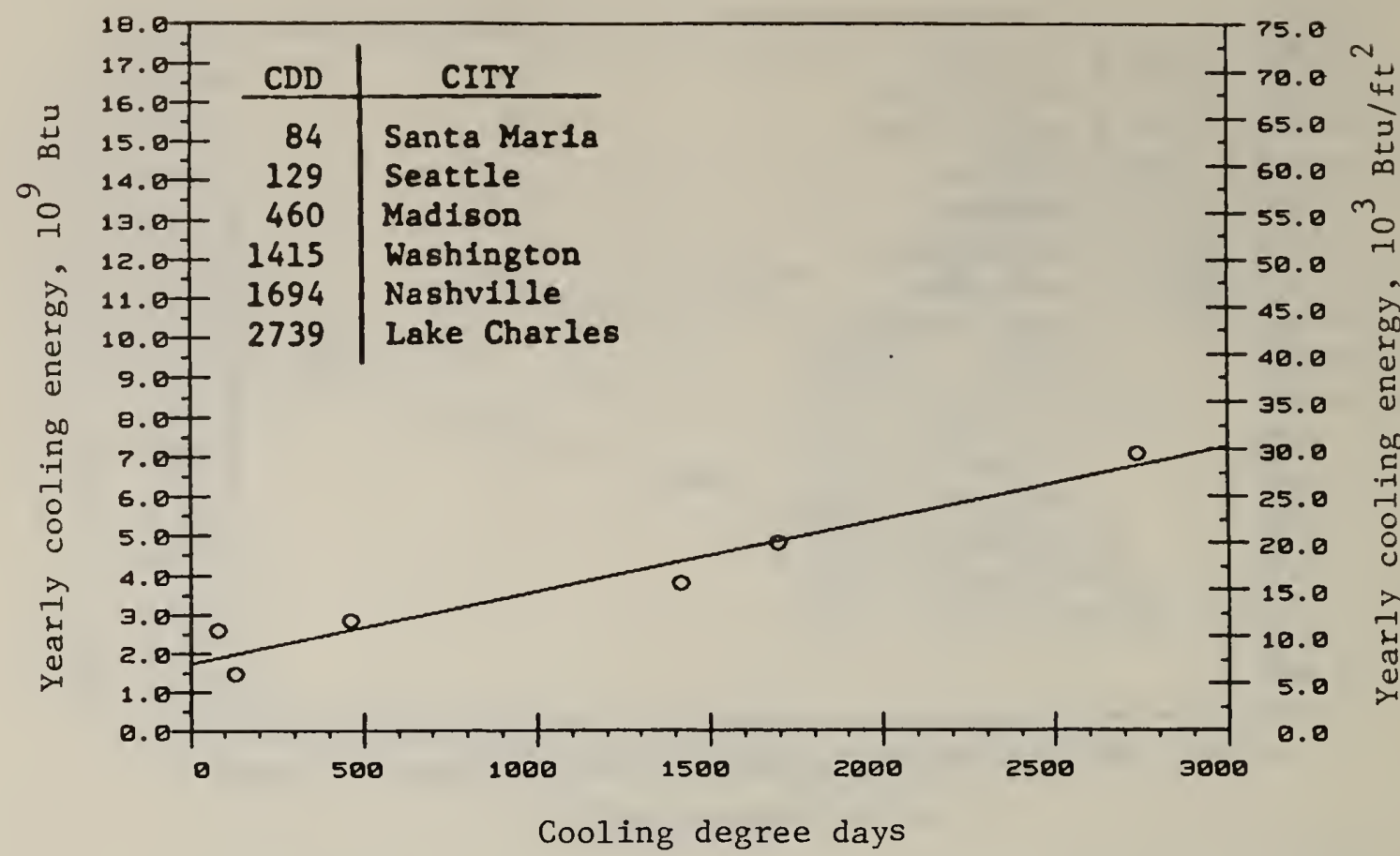

Figure 11. Cooling energy consumption of case 9--base VAV with enthalpy. economy cycle

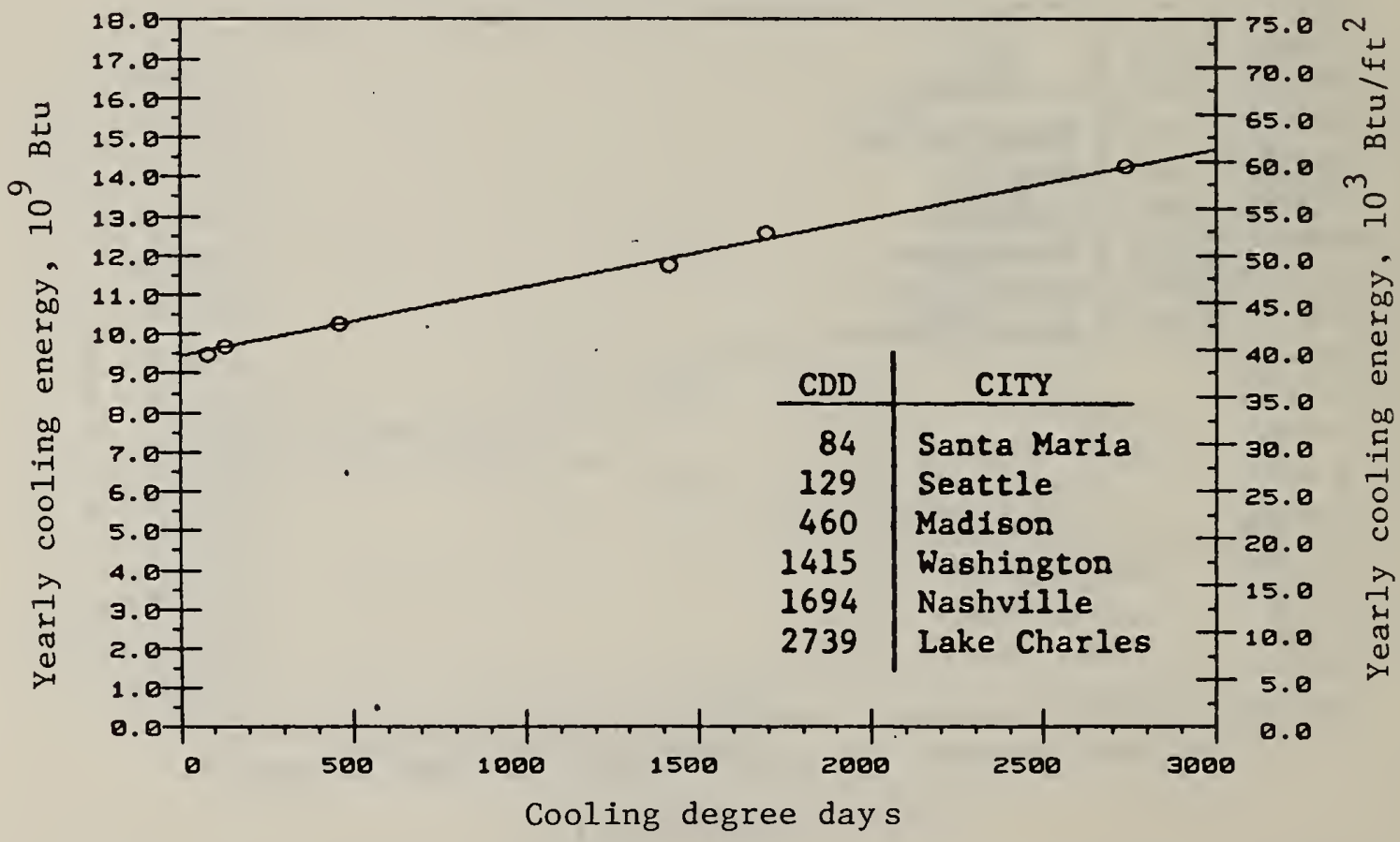

Figure 12. Cooling energy consumption of case 10--base RH for interior zones, base DD for perimeter zones 


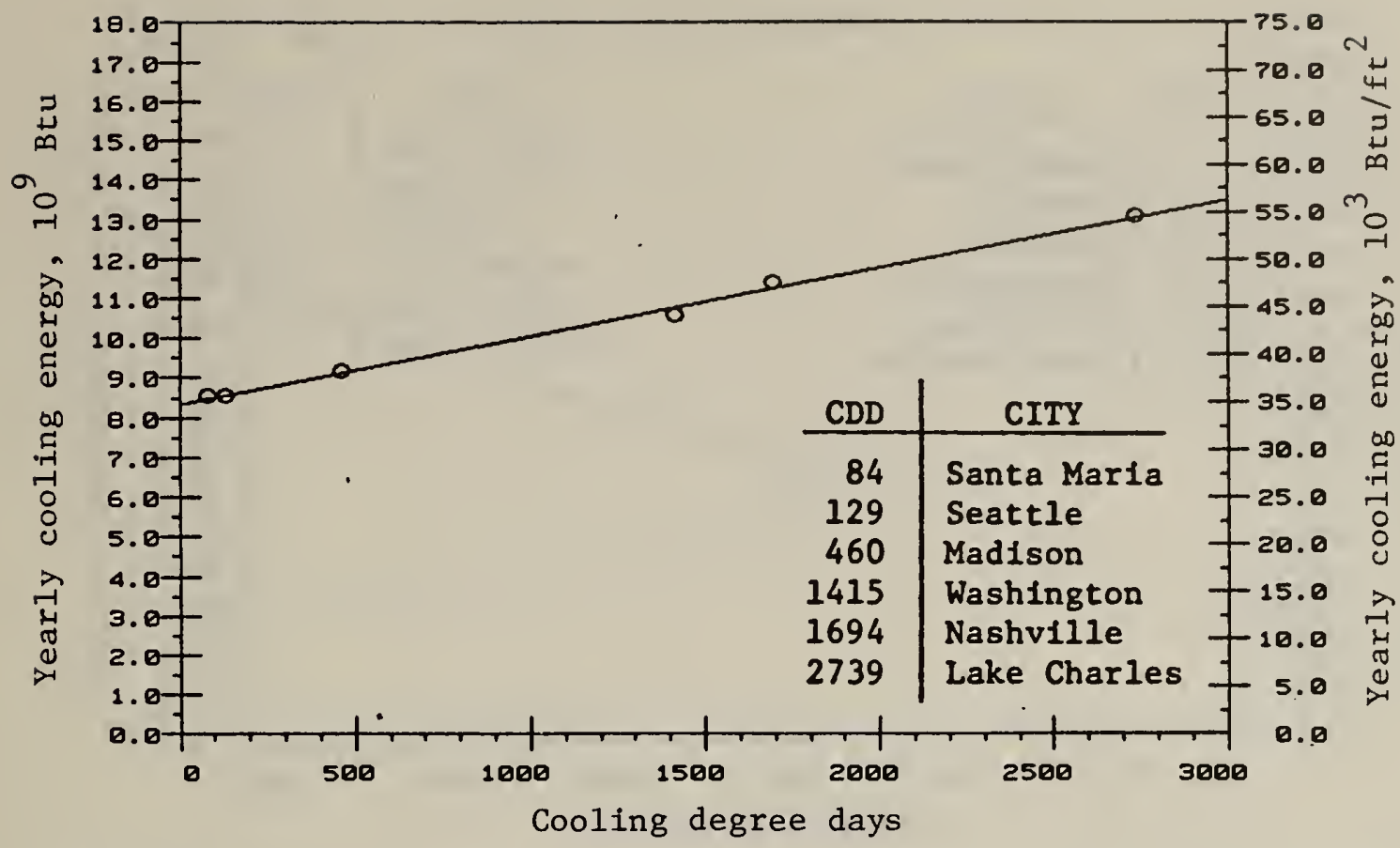

Figure 13. Cooling energy consumption of case 11--base VAV for interior zones, base DD for perimeter zones

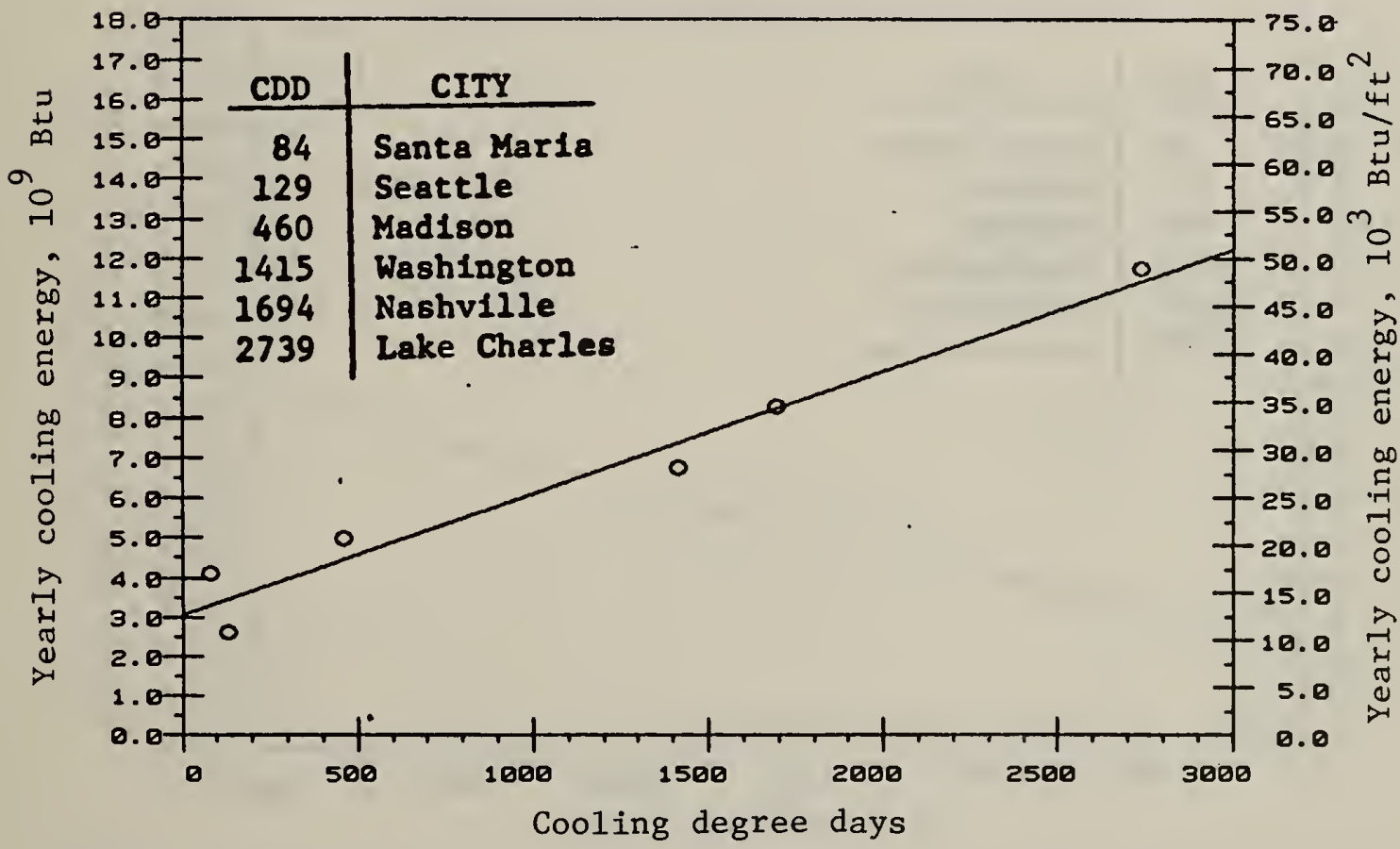

Figure 14. Cooling energy consumption of case 12--base RH with enthalpy economy cycle for interior zones, base DD with enthalpy economy cycle for perimeter zones 


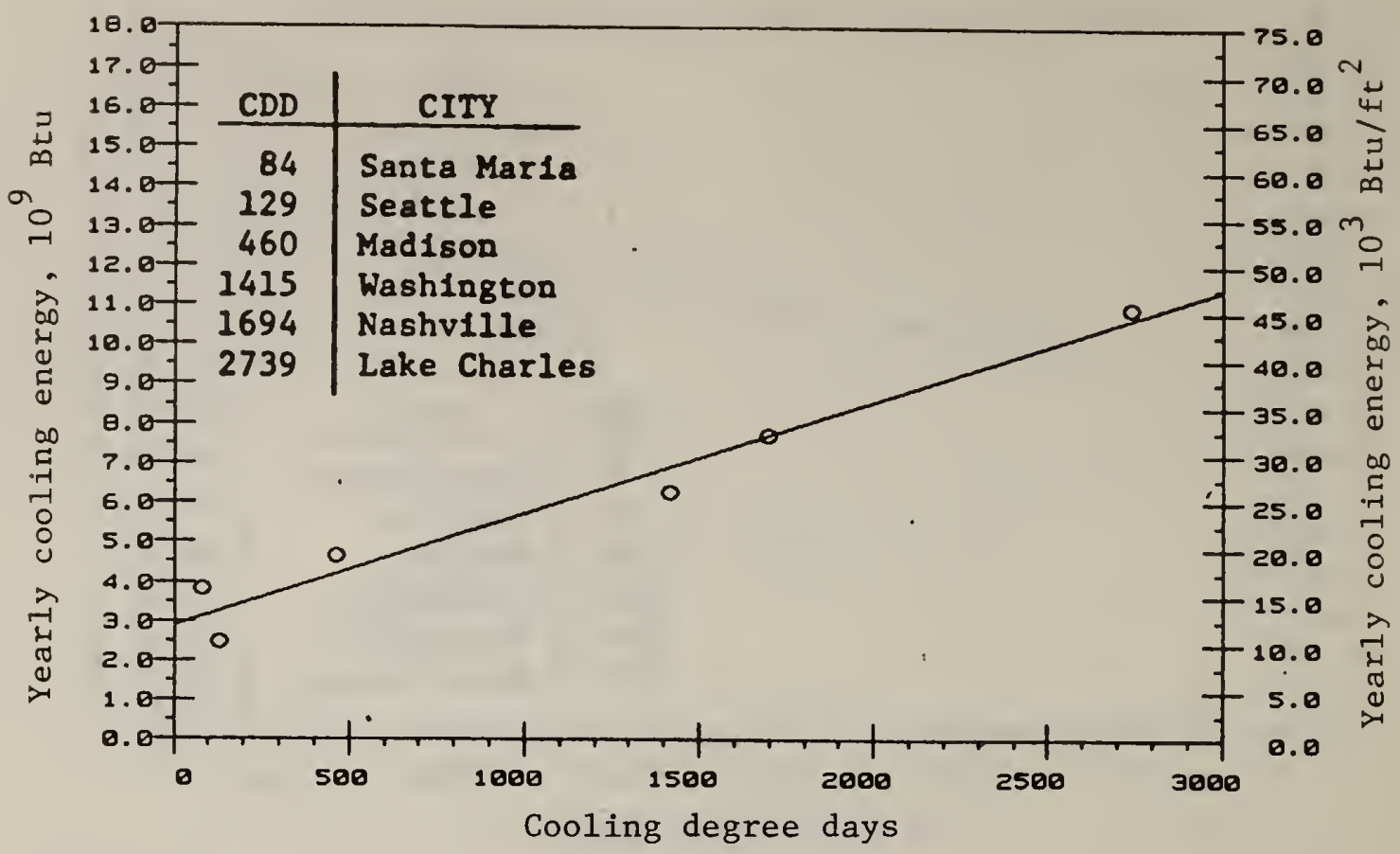

Figure 15. Cooling energy consumption of case 13--base VAV with enthalpy economy cycle for interior zones, base DD with enthalpy economy cycle and hot deck reset by outside air for perimeter zones

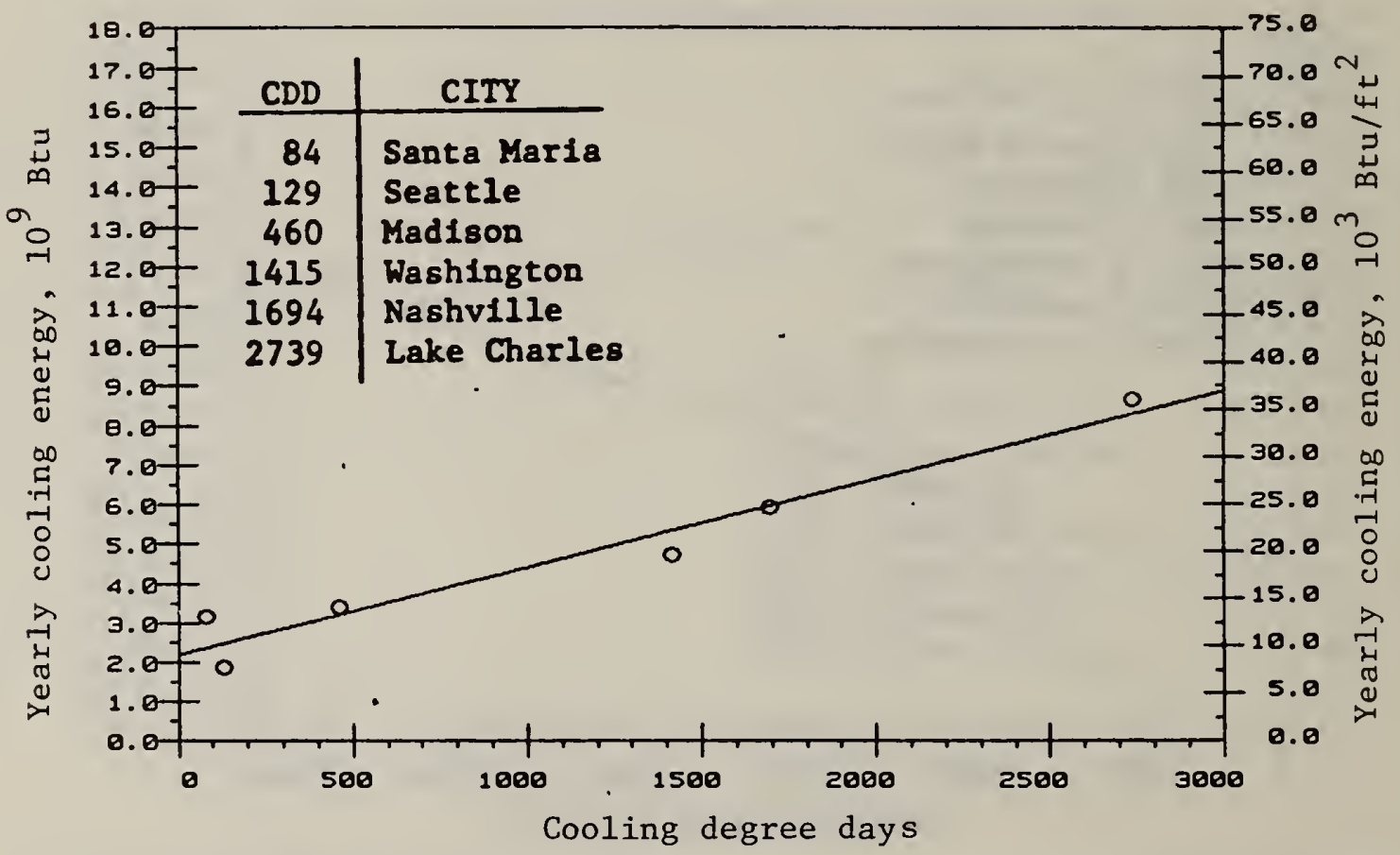

Figure 16. Cooling energy consumption of case 14--base RH with enthalpy economy cycle for interior zones, base DD with enthalpy economy cycle and hot deck reset by outside air for perimeter zones 


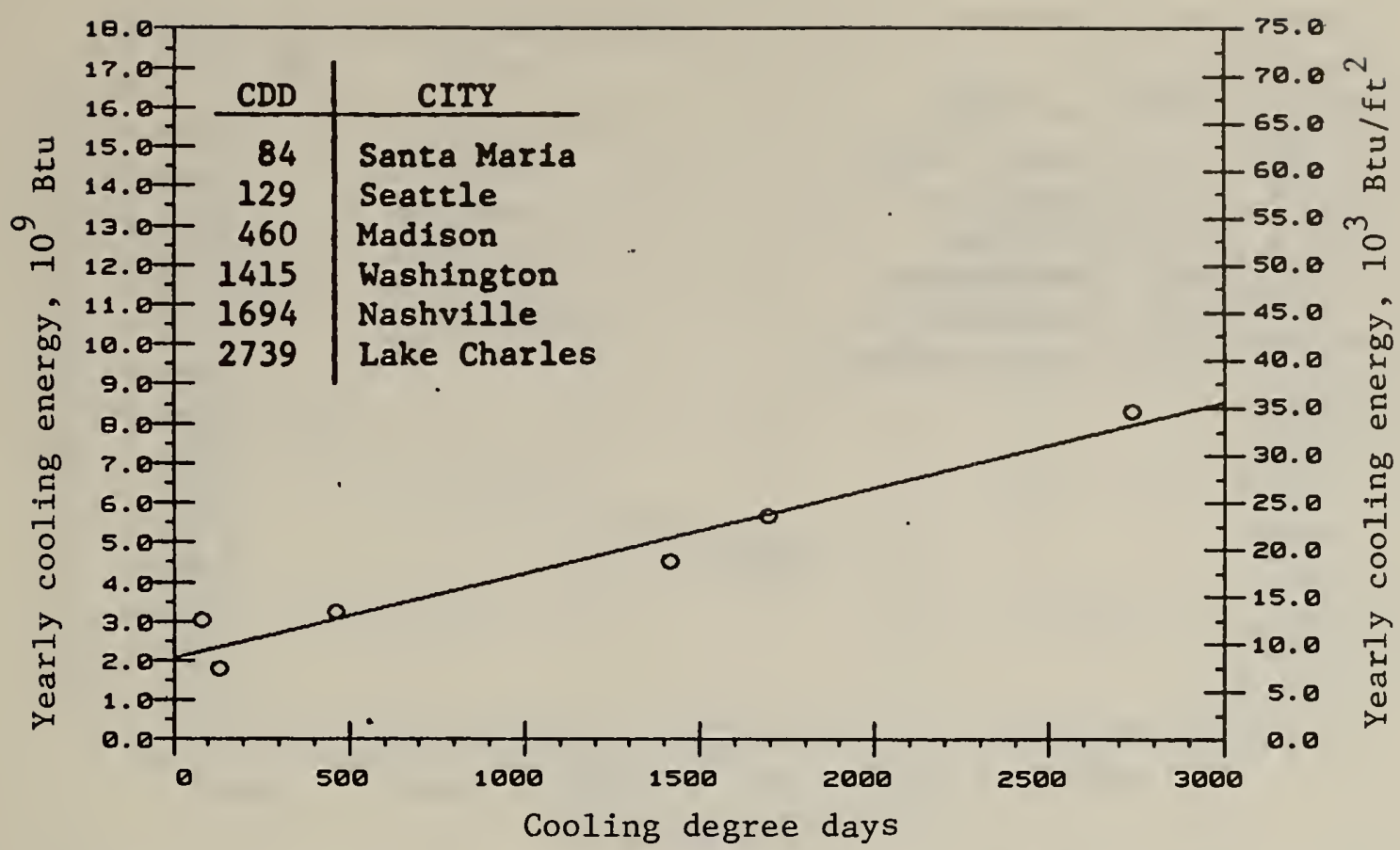

Figure 17. Cooling energy consumption of case 15--base VAV with enthalpy economy cycle for interior zones, base DD with enthalpy economy cycle and hot deck reset by outside air for perimeter zones

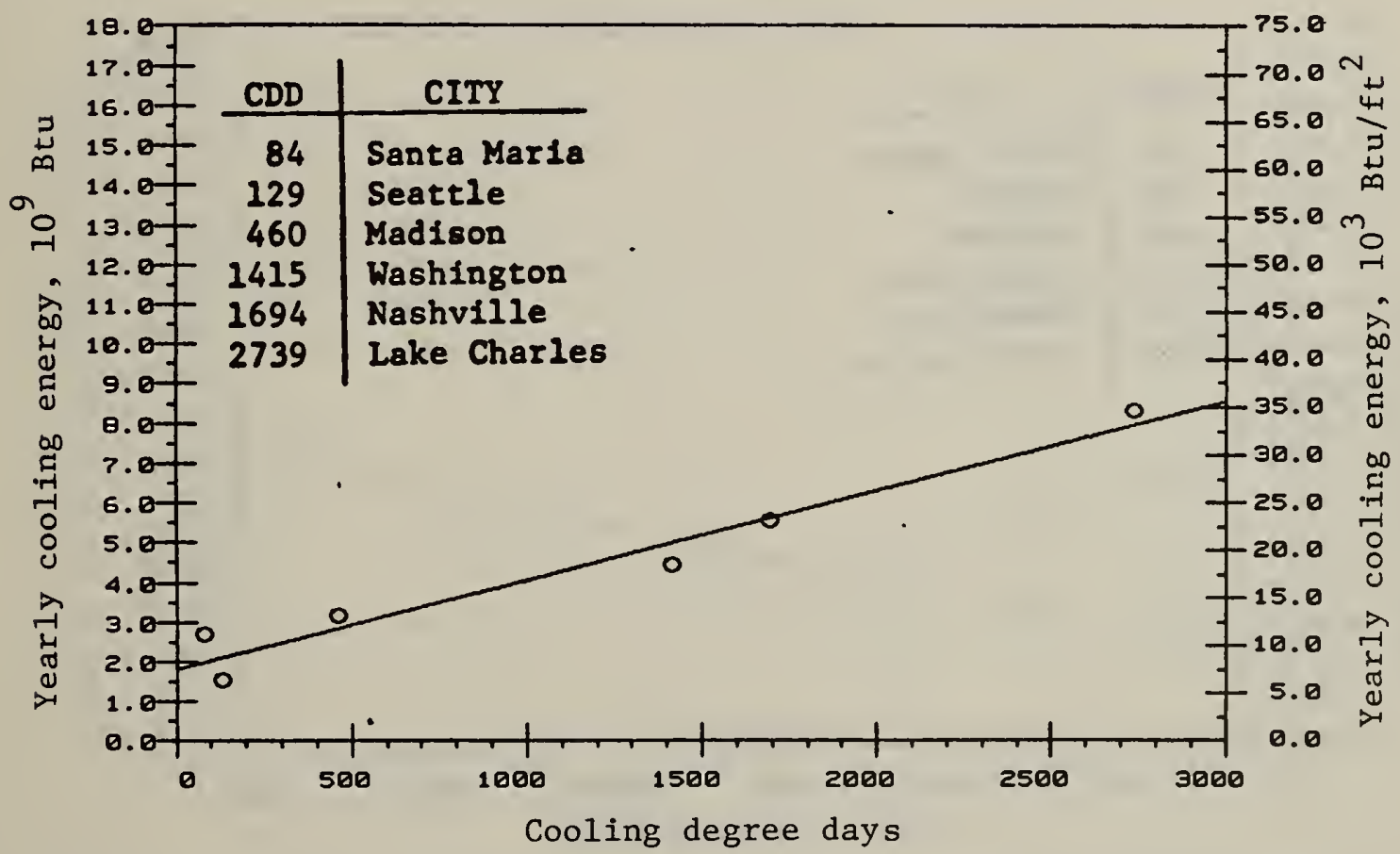

Figure 18. Cooling energy consumption of case 16--base RH with enthalpy economy cycle and supply air reset by zone demand for interior zones, base DD with enthalpy economy cycle and hot - cold decks reset by zone demands for perimeter zones 


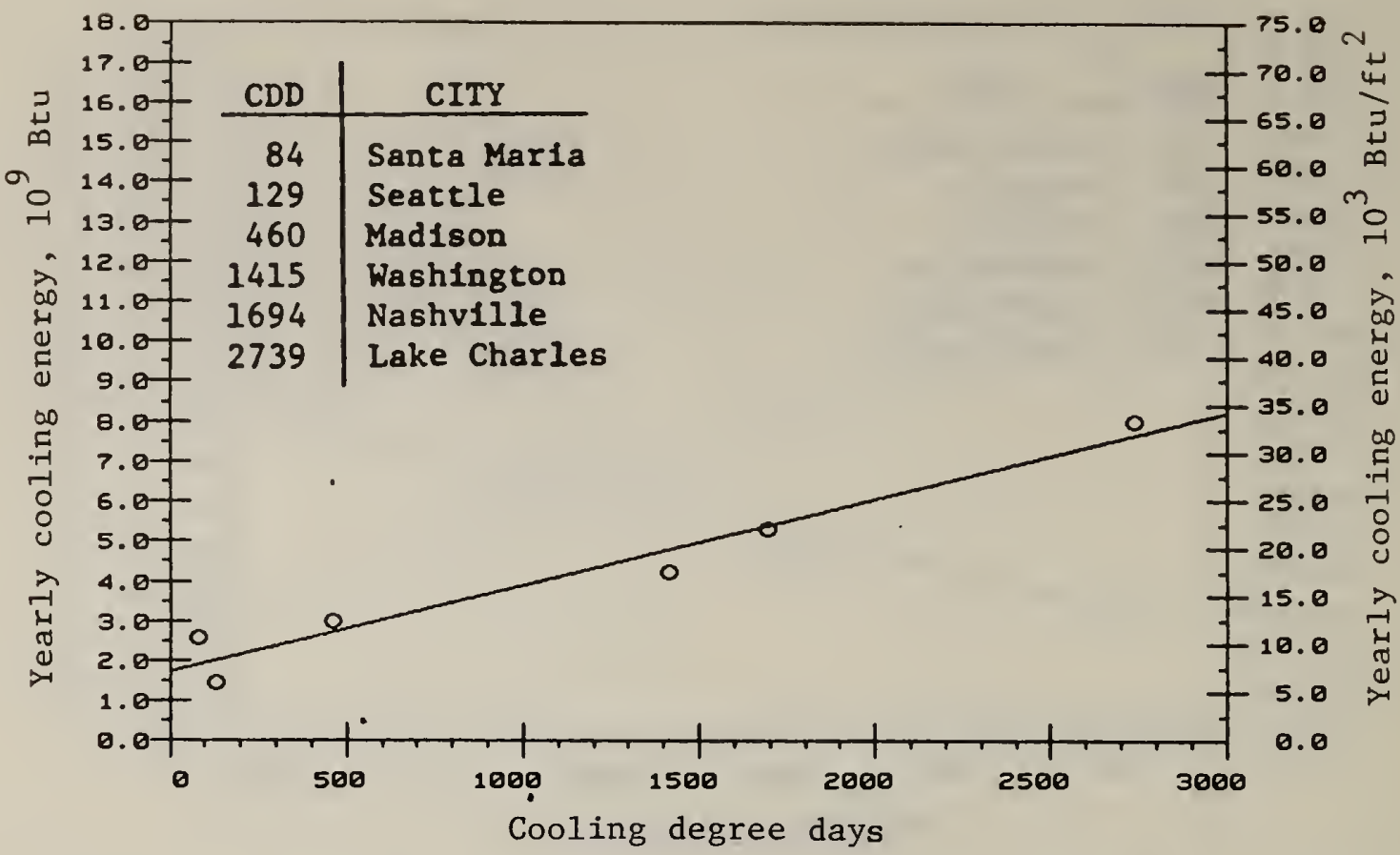

Figure 19. Cooling energy consumption of case 17--base VAV with enthalpy economy cycle for interior zones, base DD with enthalpy economy cycle and hot-cold decks reset by zone demands for perimeter zones

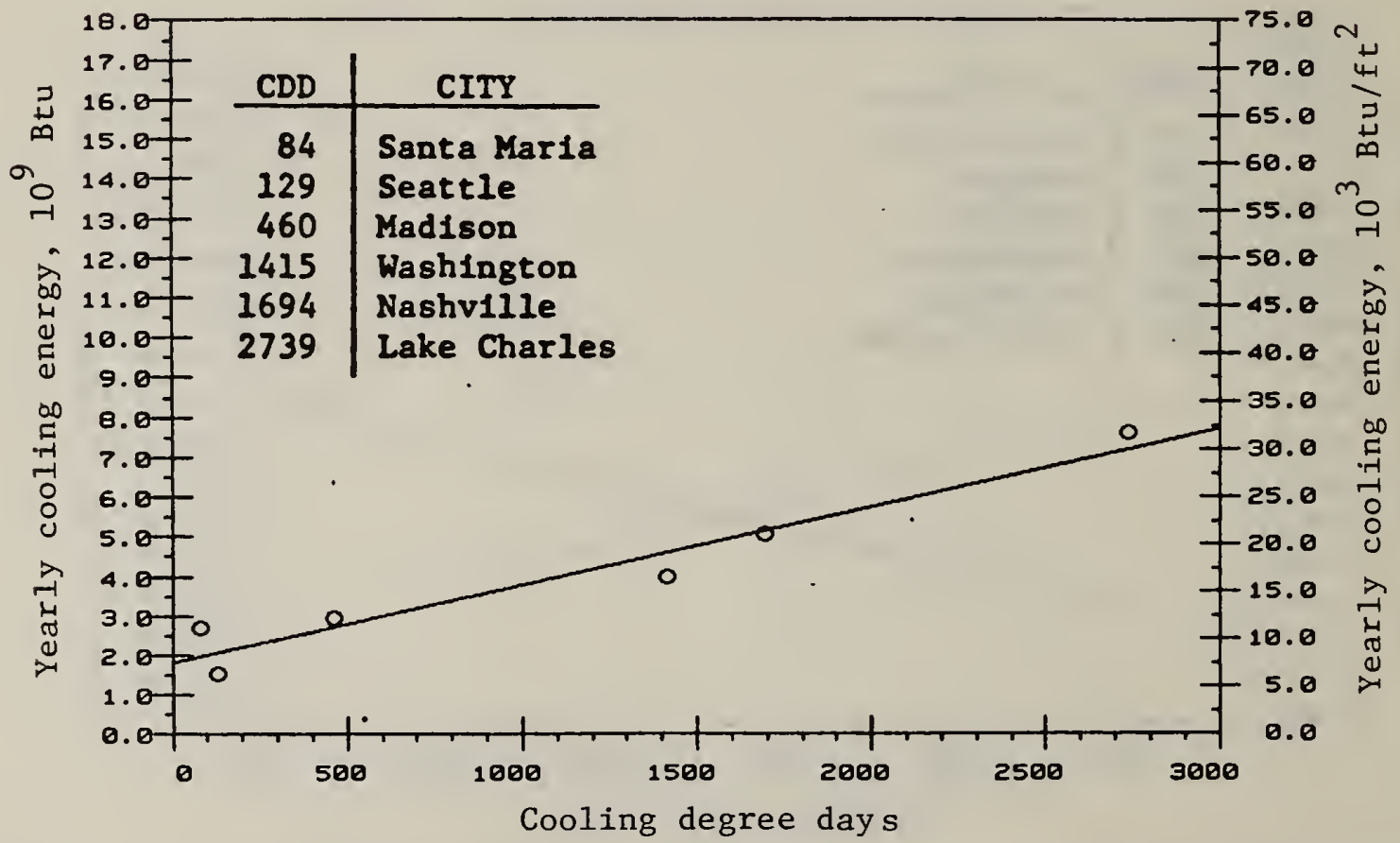

Figure 20. Cooling energy consumption of case 18--base RH with enthalpy economy cycle and supply air reset by zone demand for interior zones, base VAV with enthalpy economy cycle for perimeter zones 


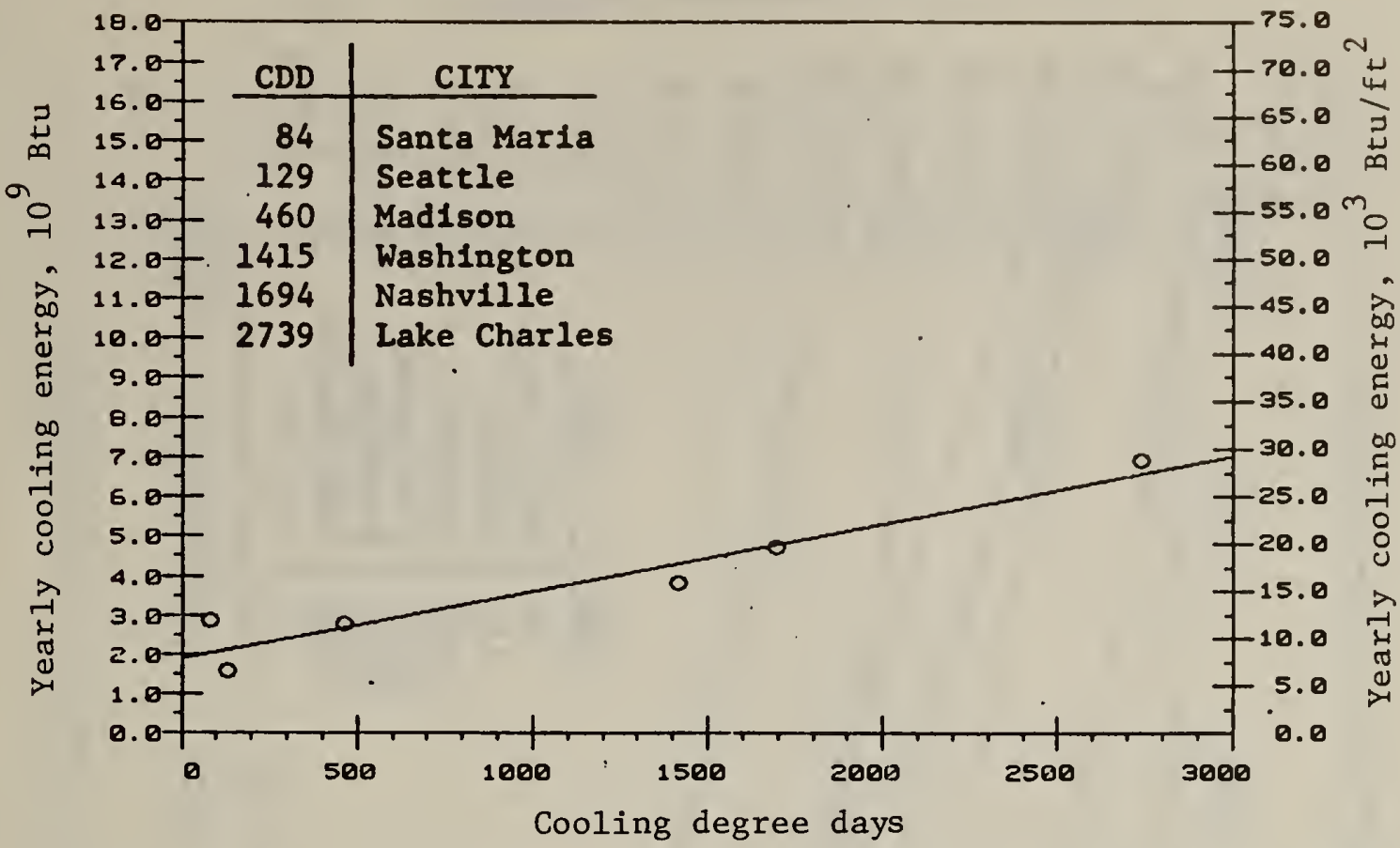

Figure 21. Cooling energy consumption of case 19--base RH with enthalpy economy cycle and supply air reset by zone demand for interior zones, fan-coil for perimeter zones

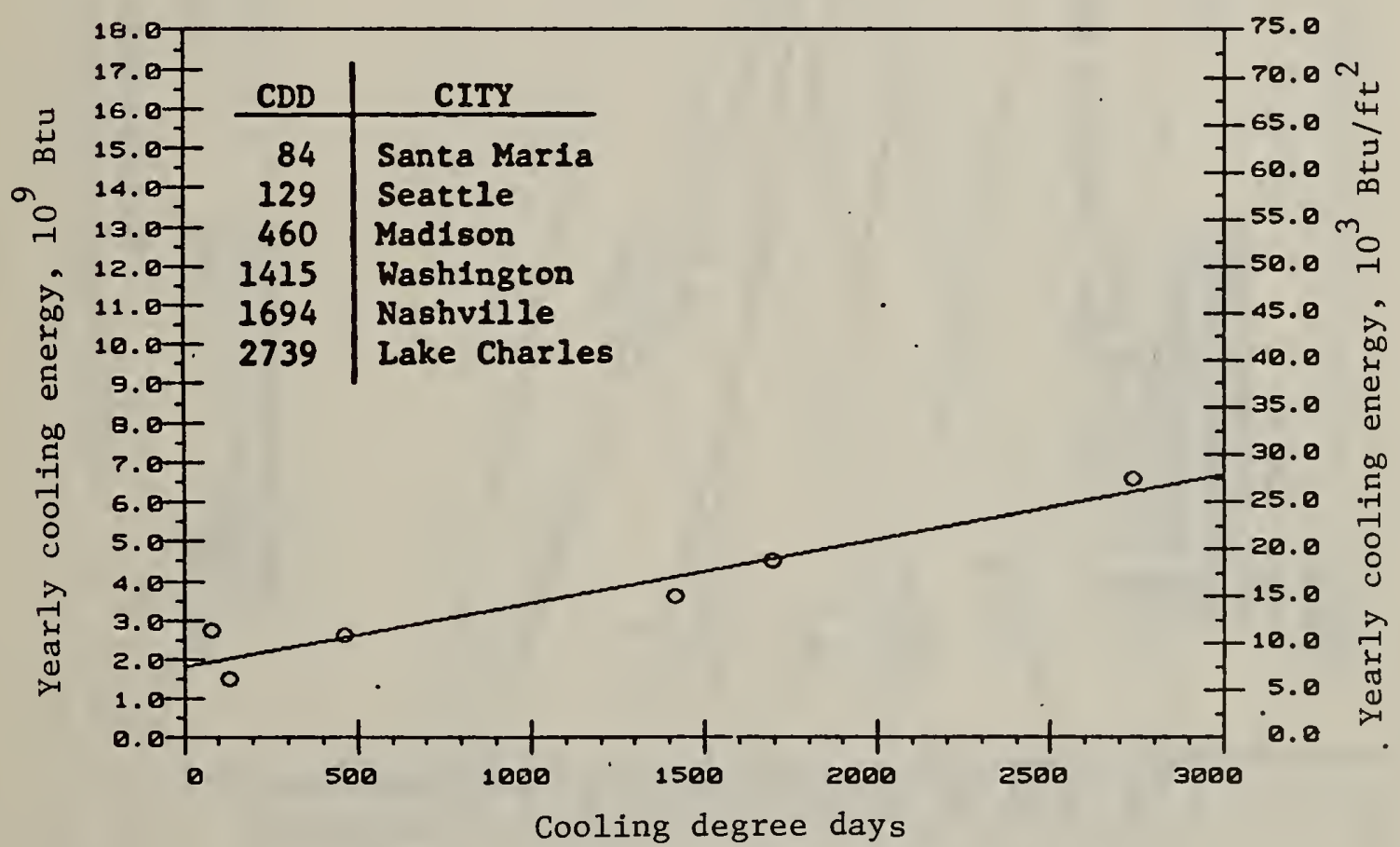

Figure 22. Cooling energy consumption of case 20--base VAV with enthalpy economy cycle for interior zones, fan-coil for perimeter zones 


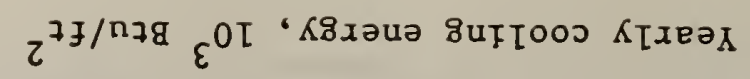
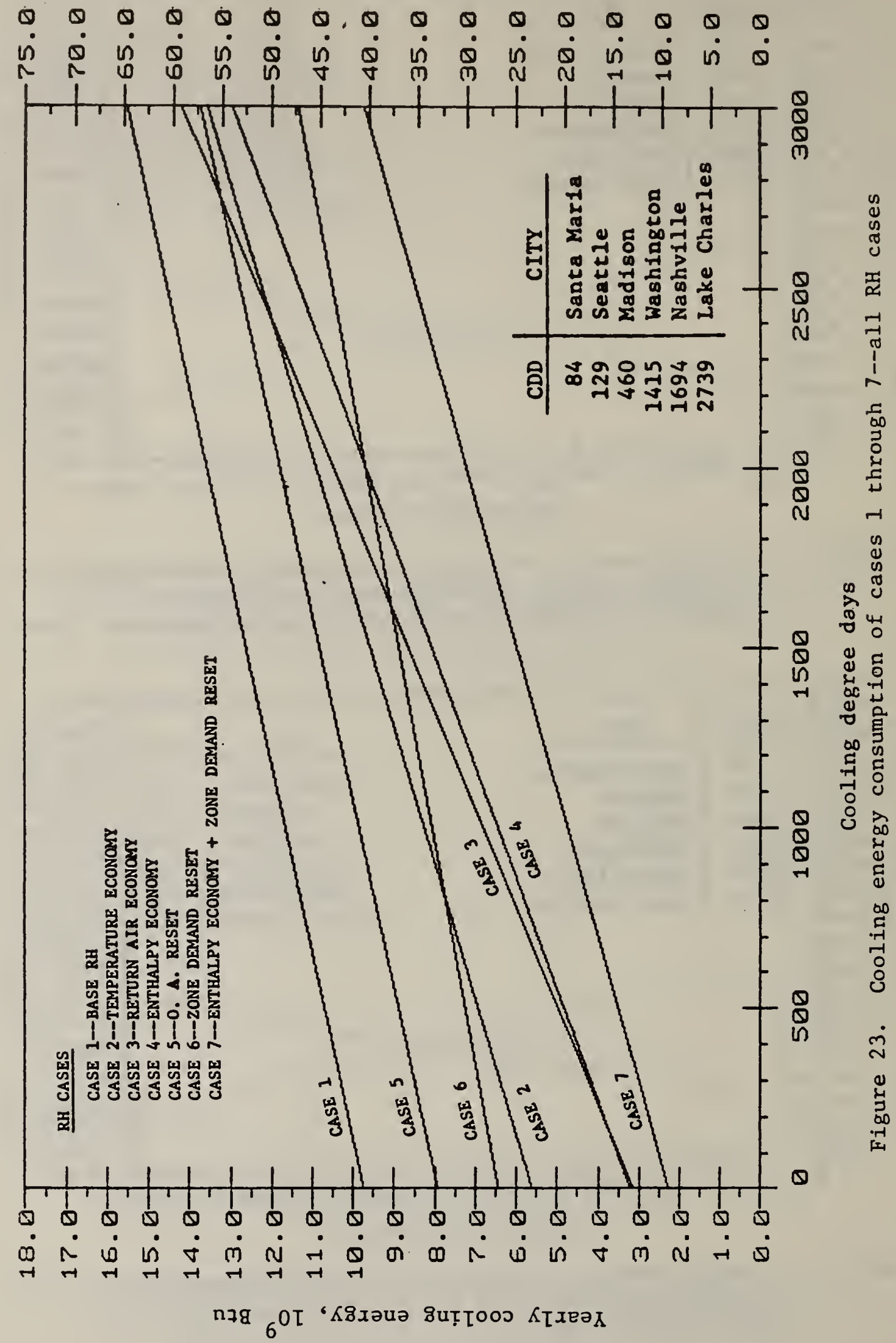


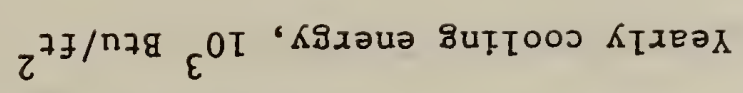

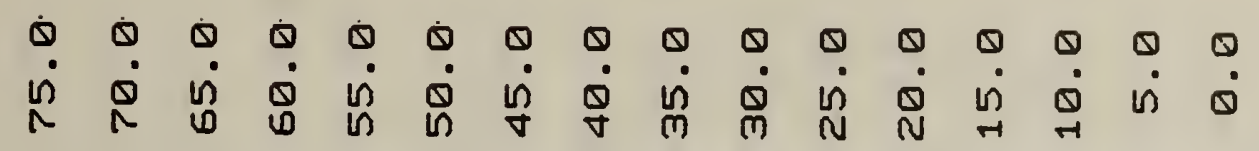

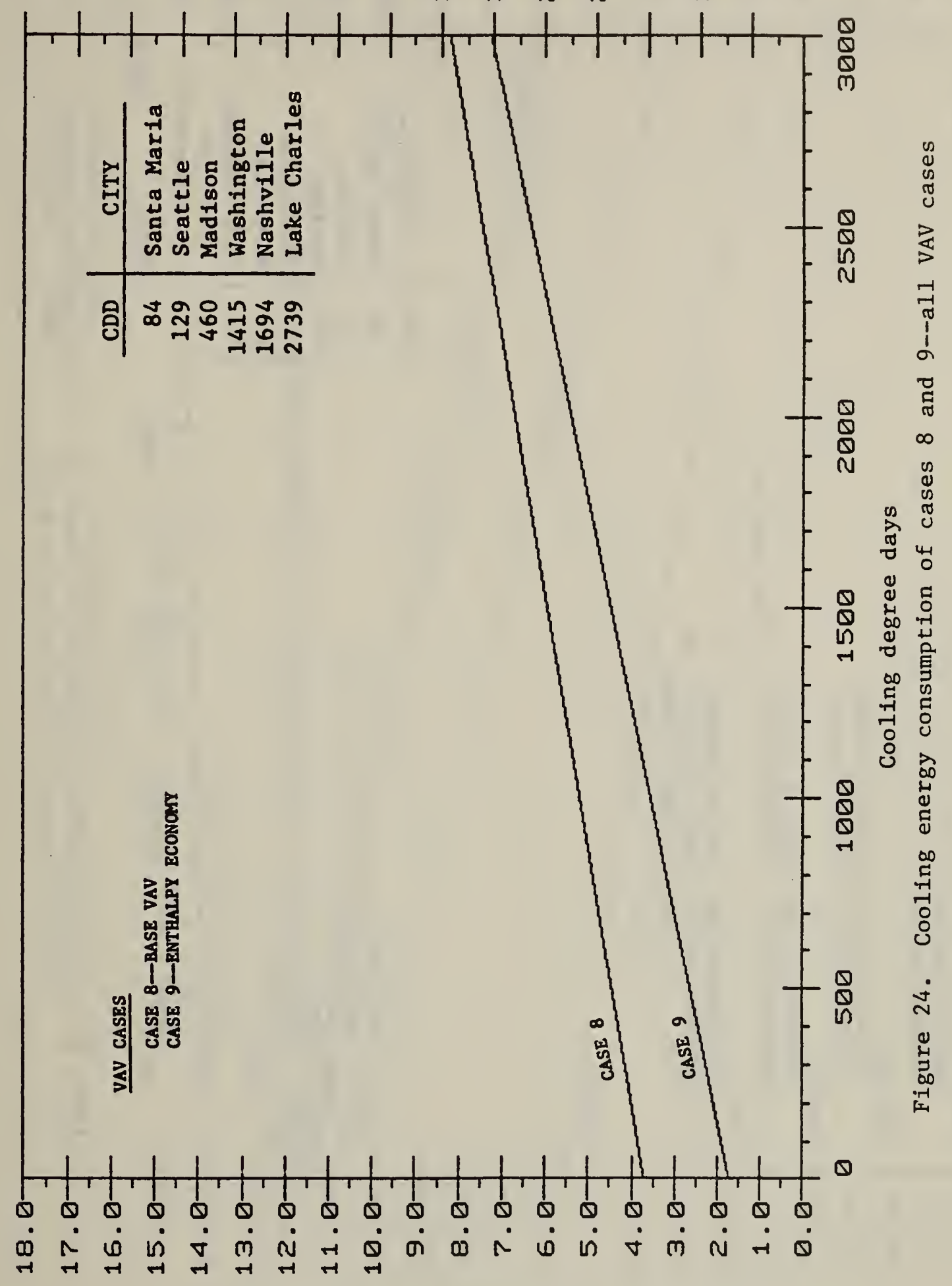

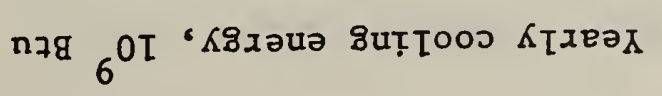




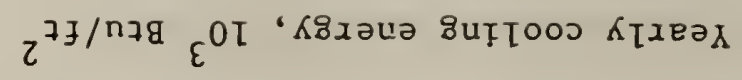

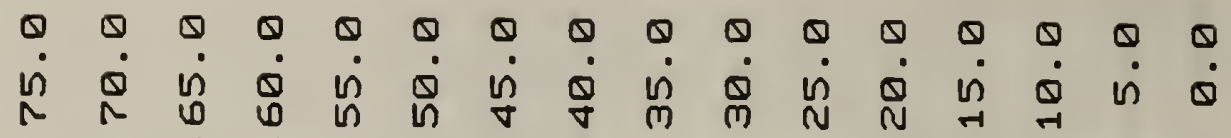

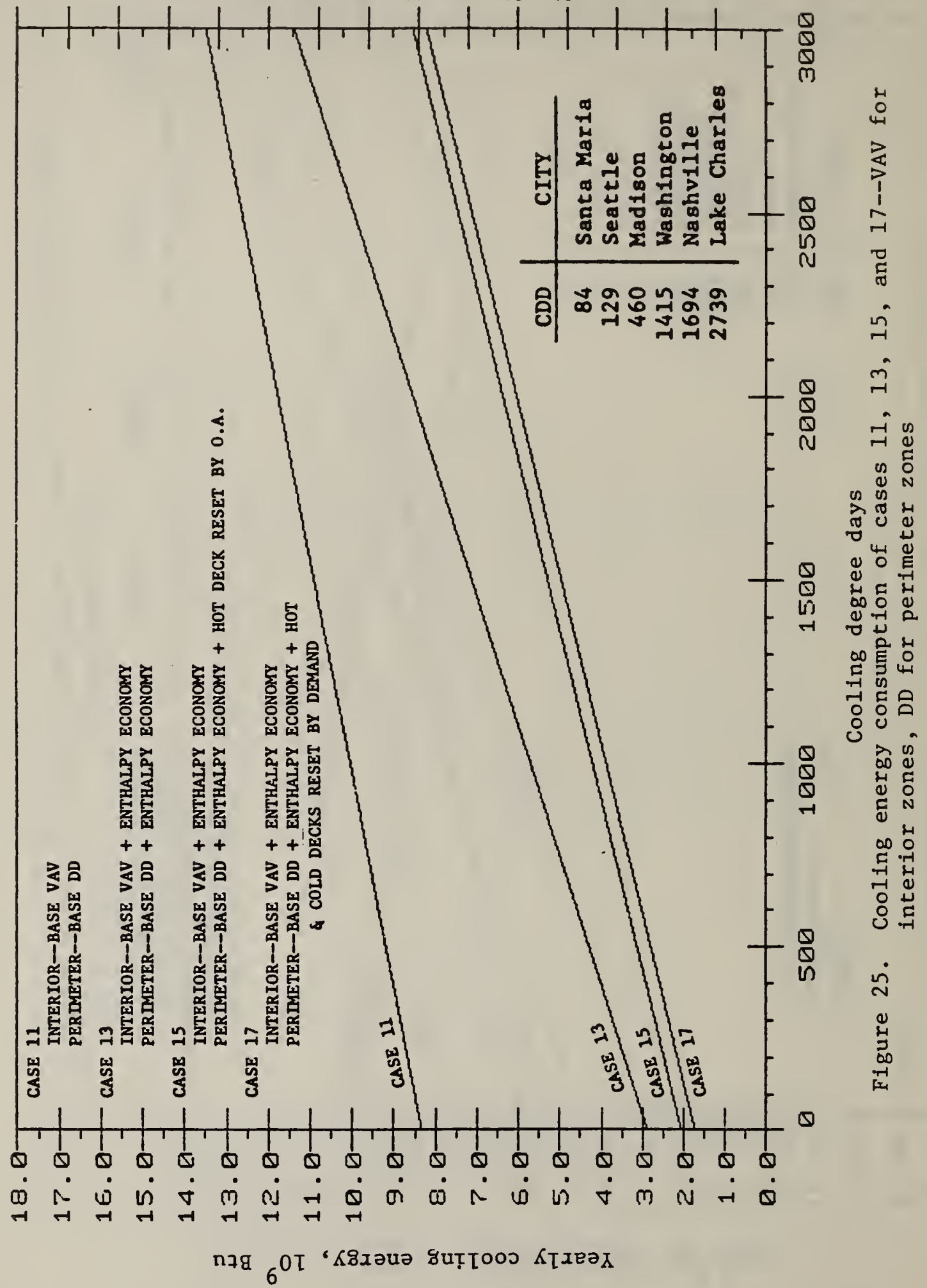




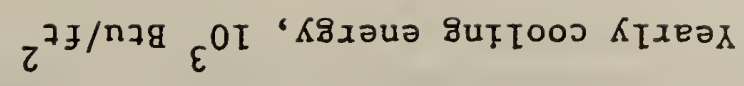

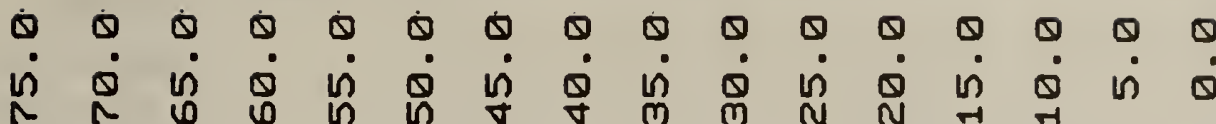

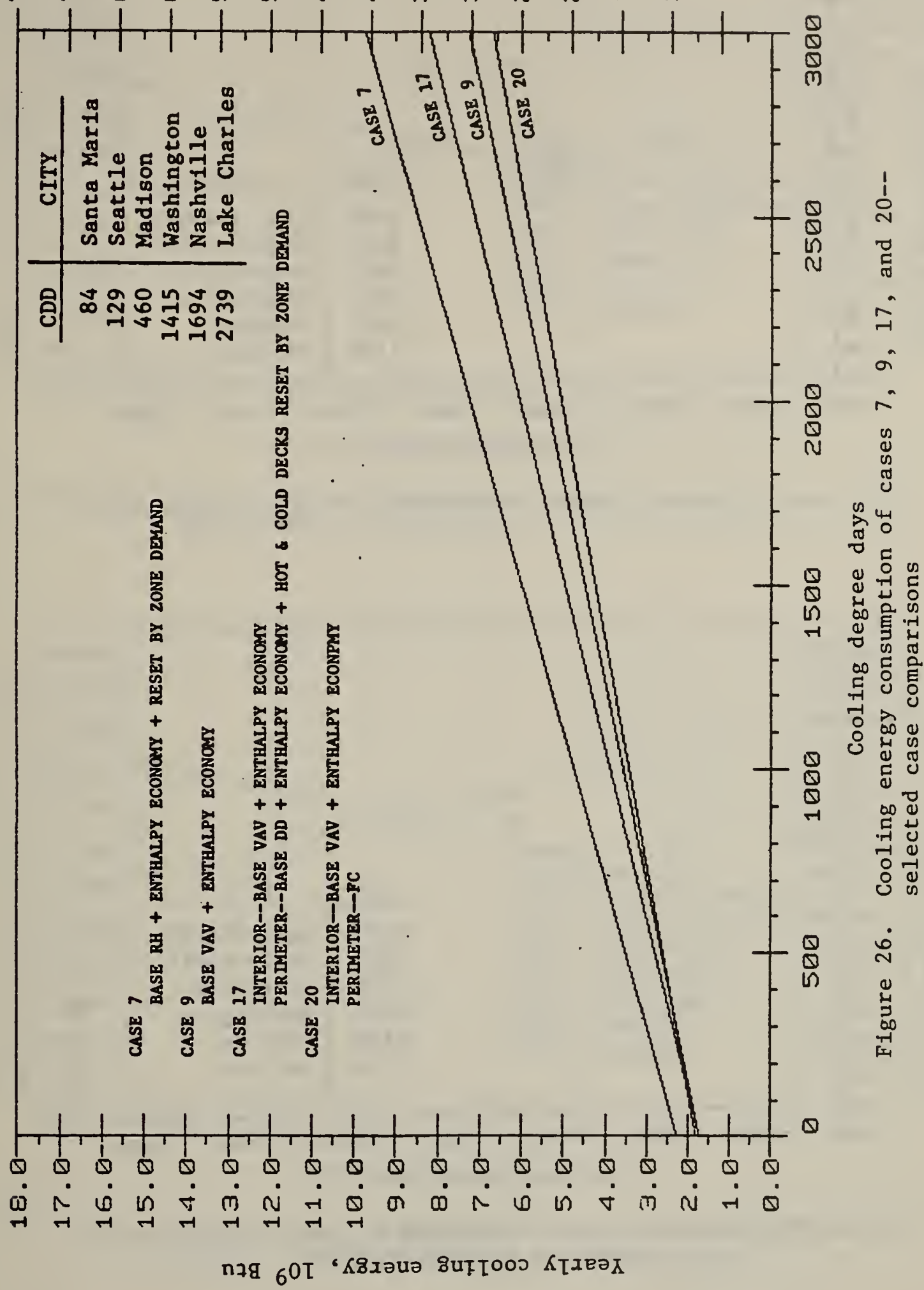




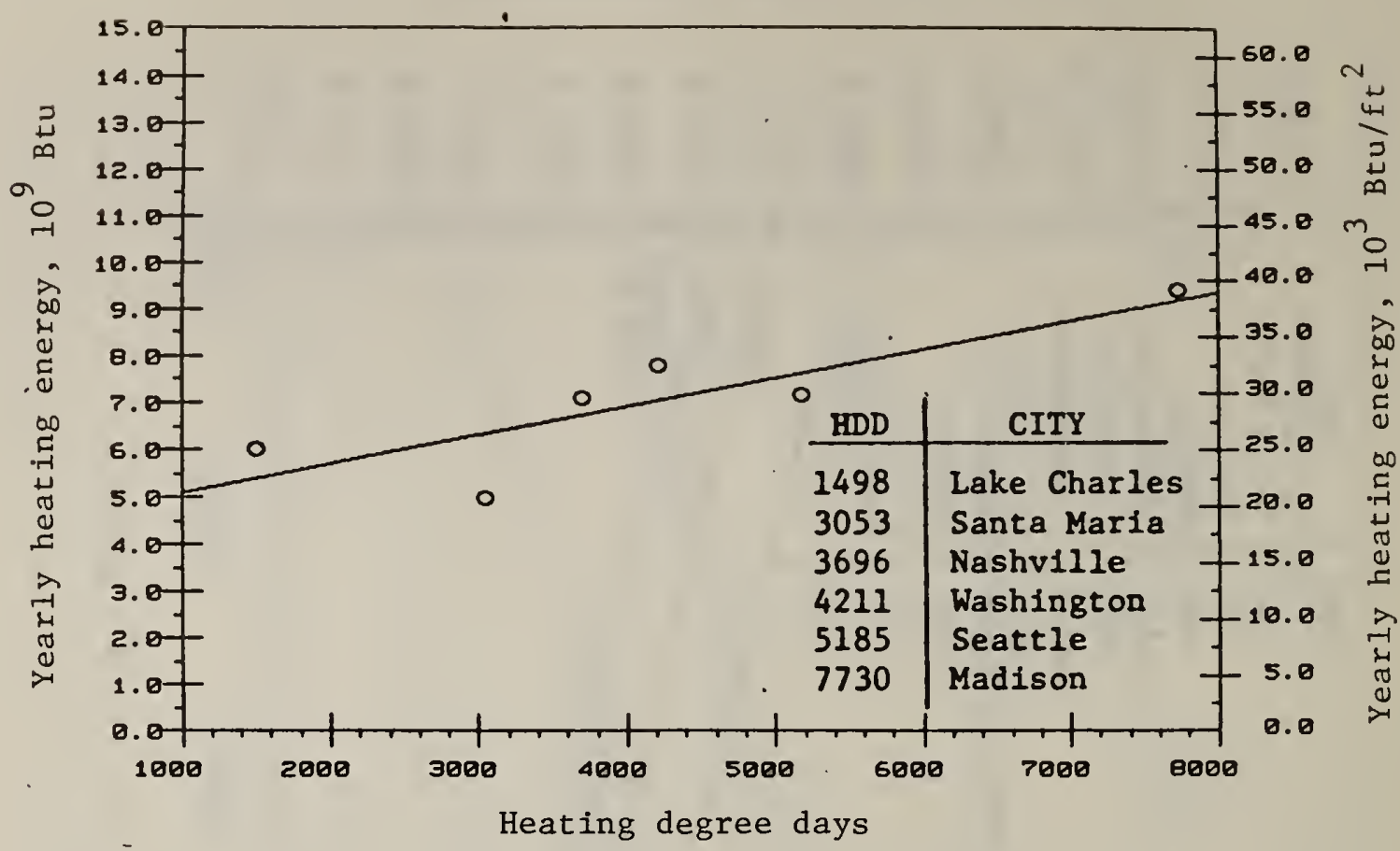

Figure 27. Heating energy consumption of case 1--base reheat

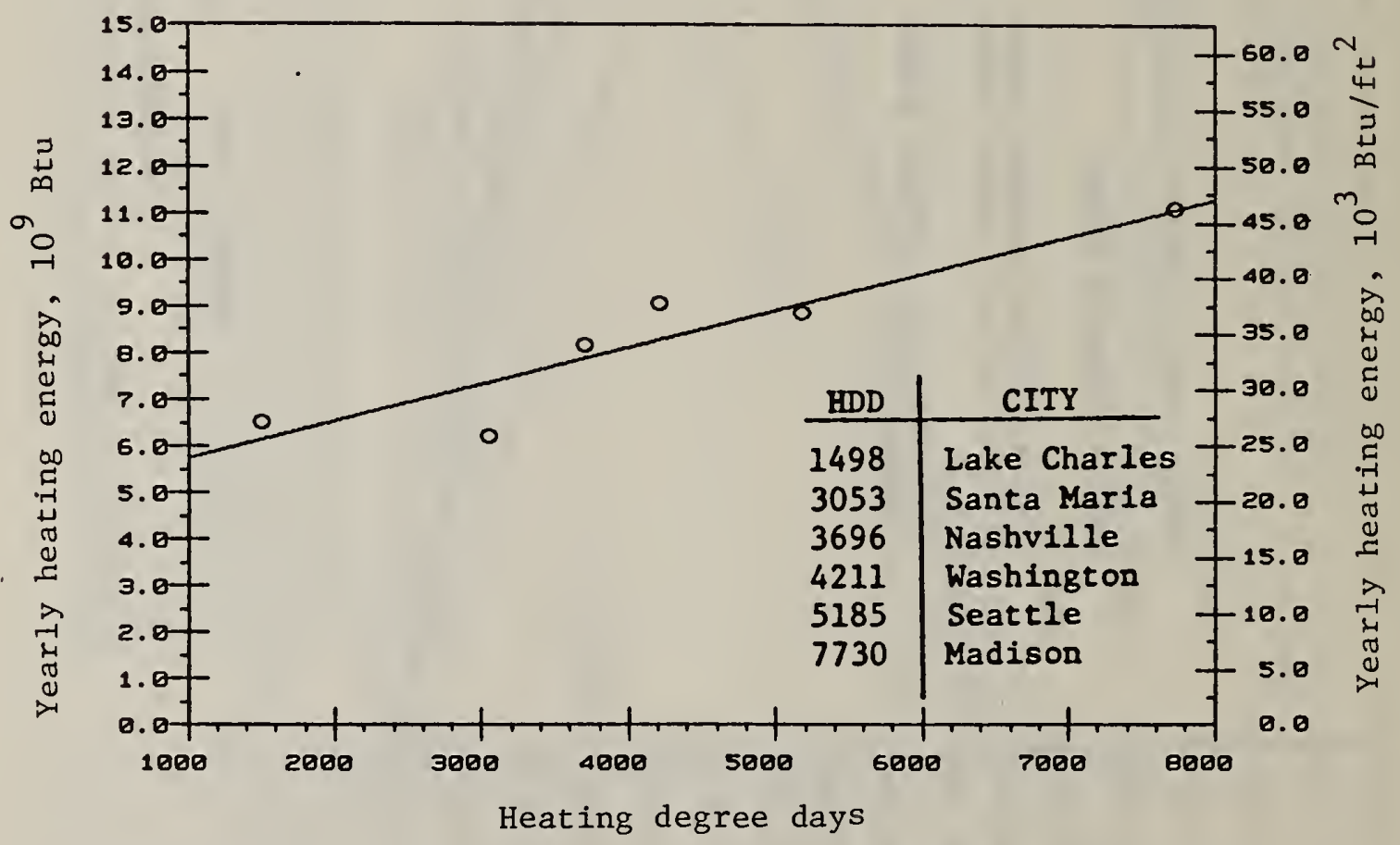

Figure 28. Heating energy consumption of case 2--base reheat with temperature economy cycle 


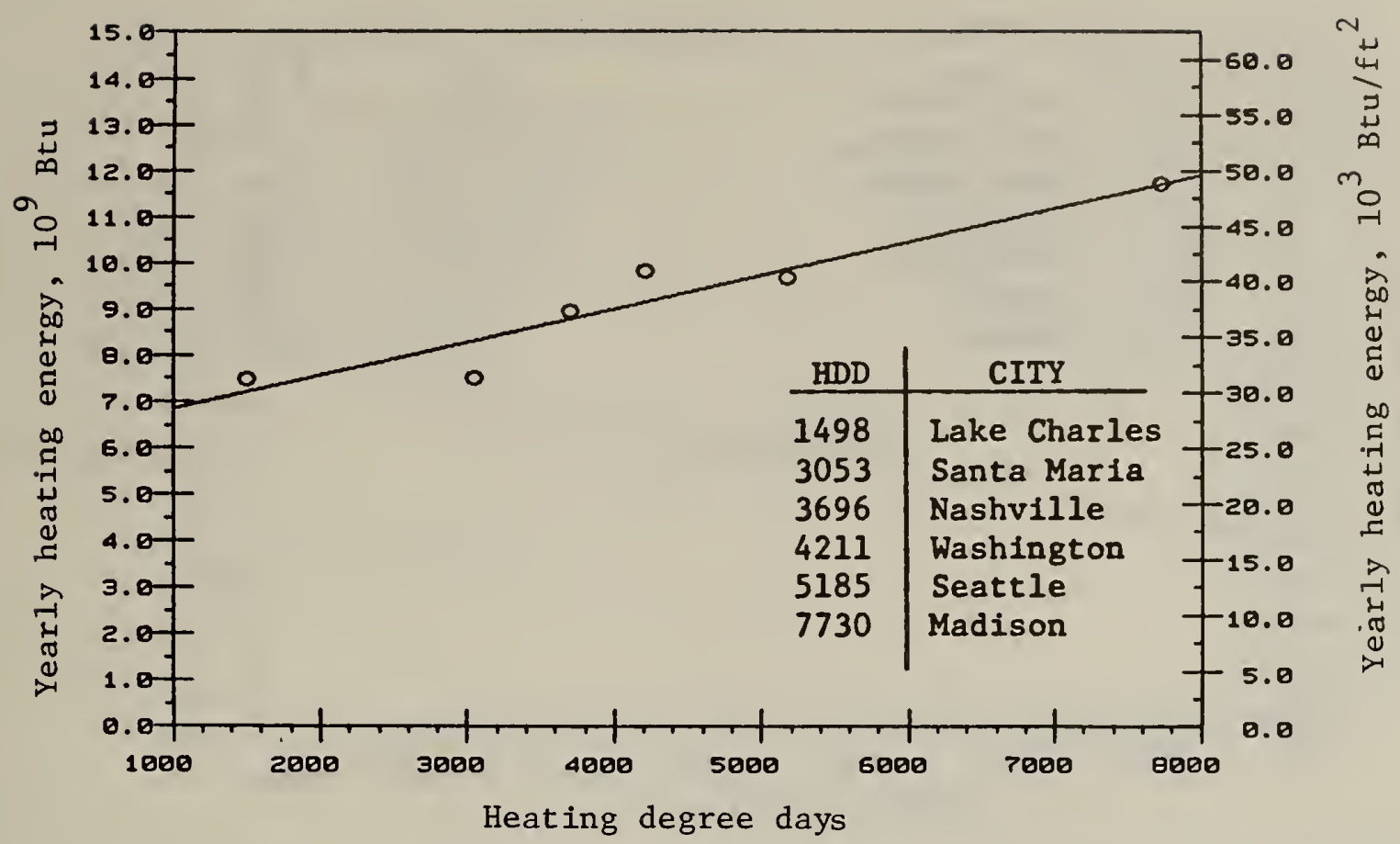

Figure 29. Heating energy consumption of case 3--base reheat with temperature economy cycle

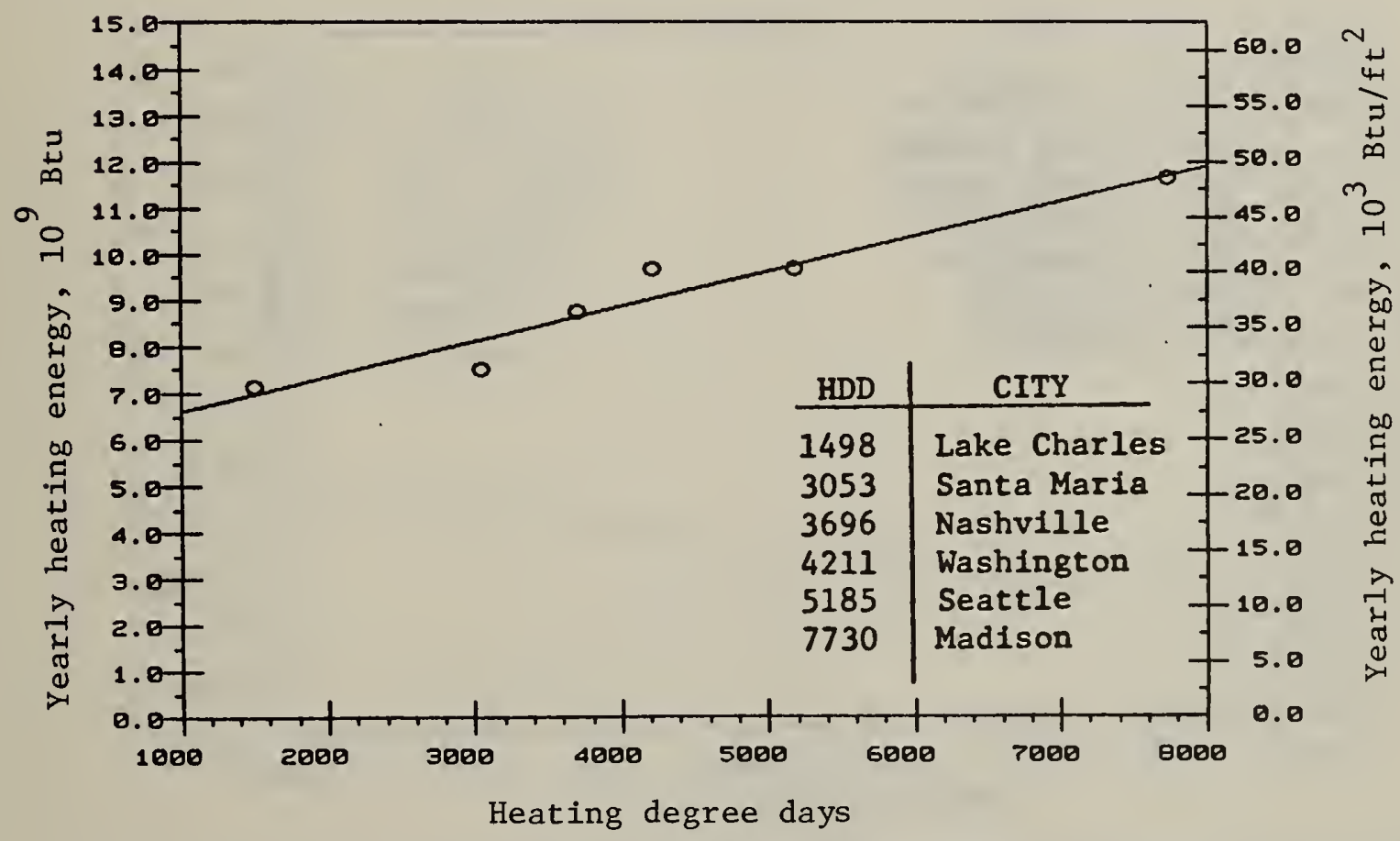

Figure 30. Heating energy consumption of case 4--base reheat with enthalpy economy cycle 


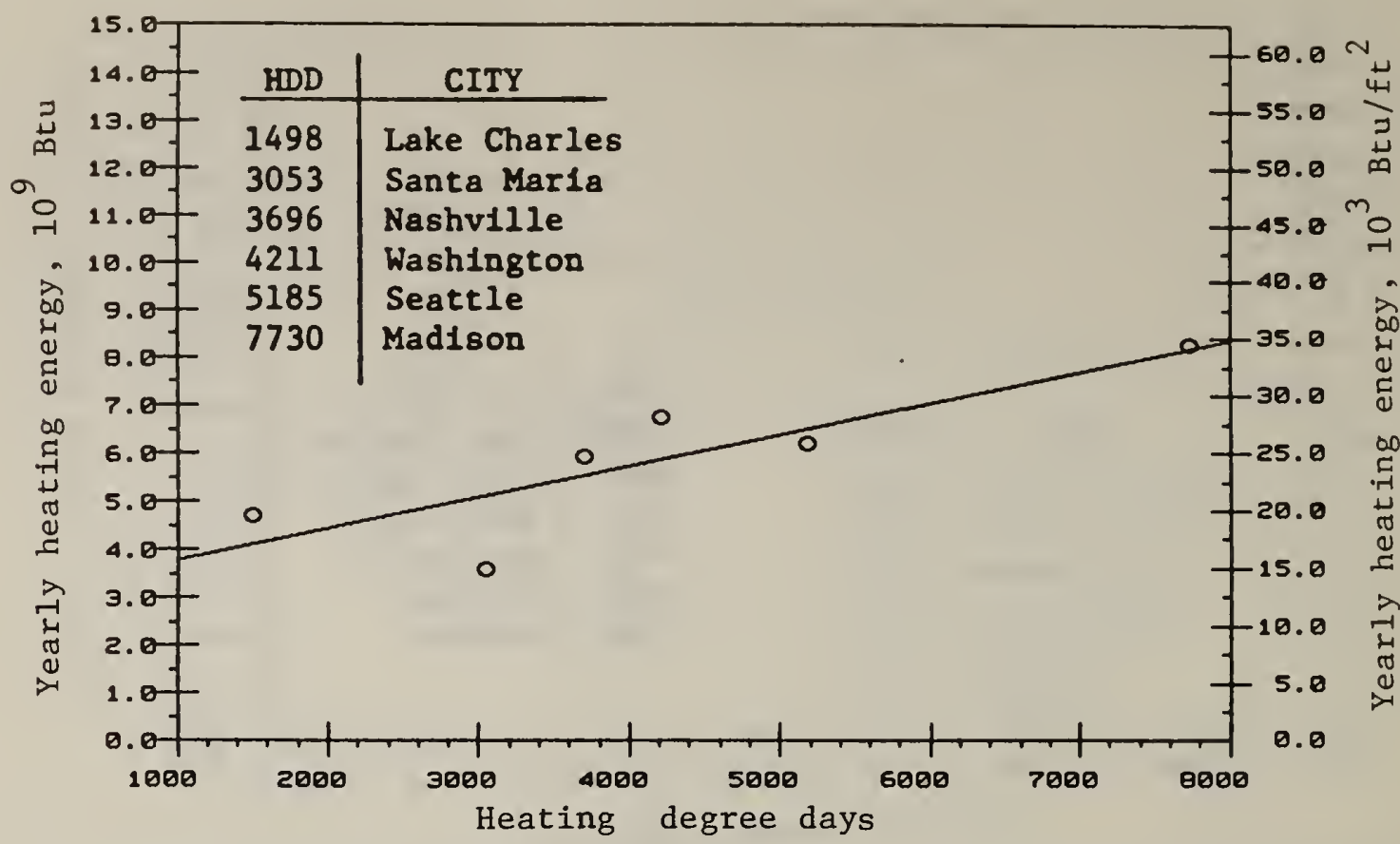

Figure 31. Heating energy consumption of case 5--base reheat with supply air reset by outside air

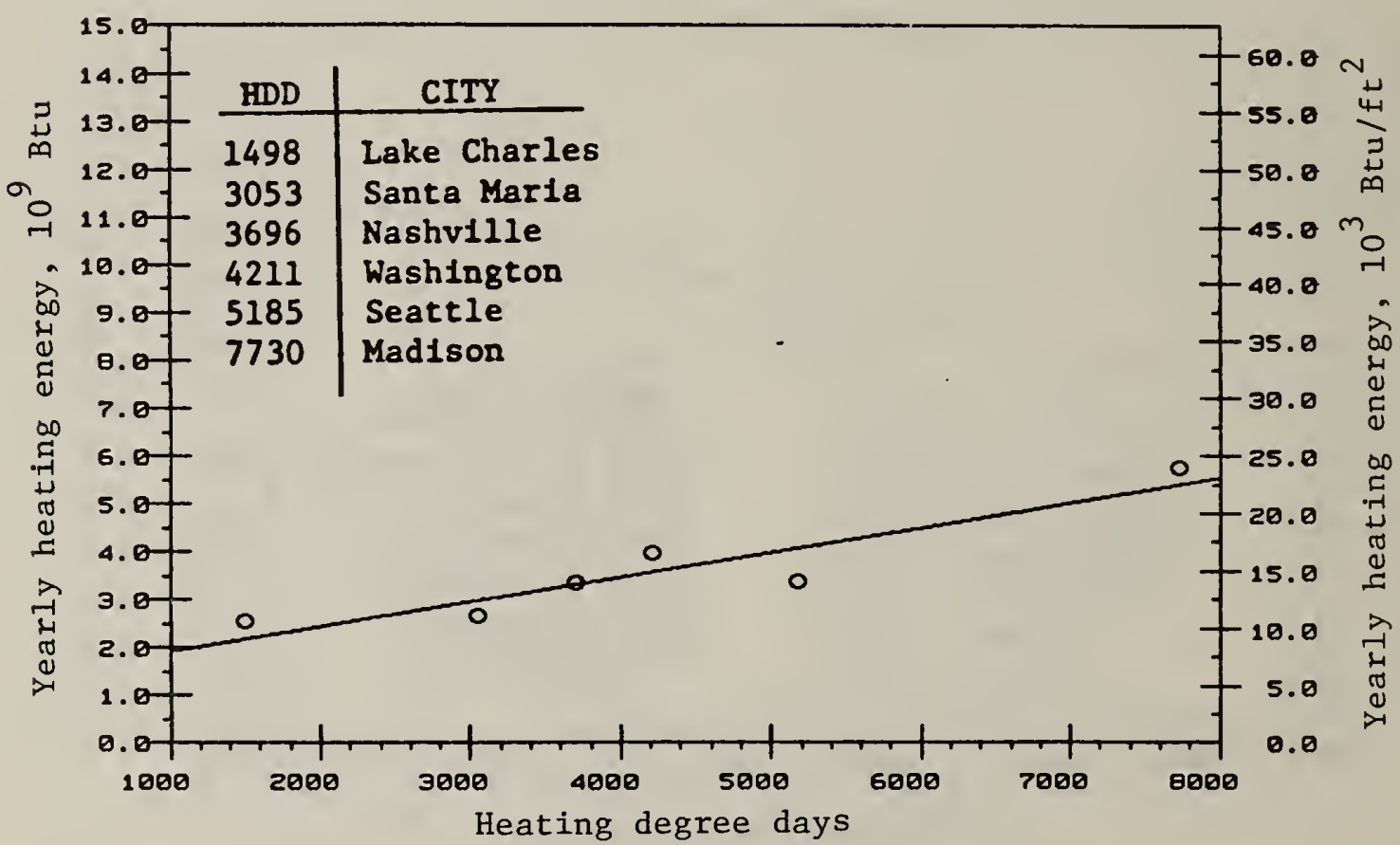

Figure 32. Heating energy consumption of case 6 --base reheat with supply air reset by zone load demand 


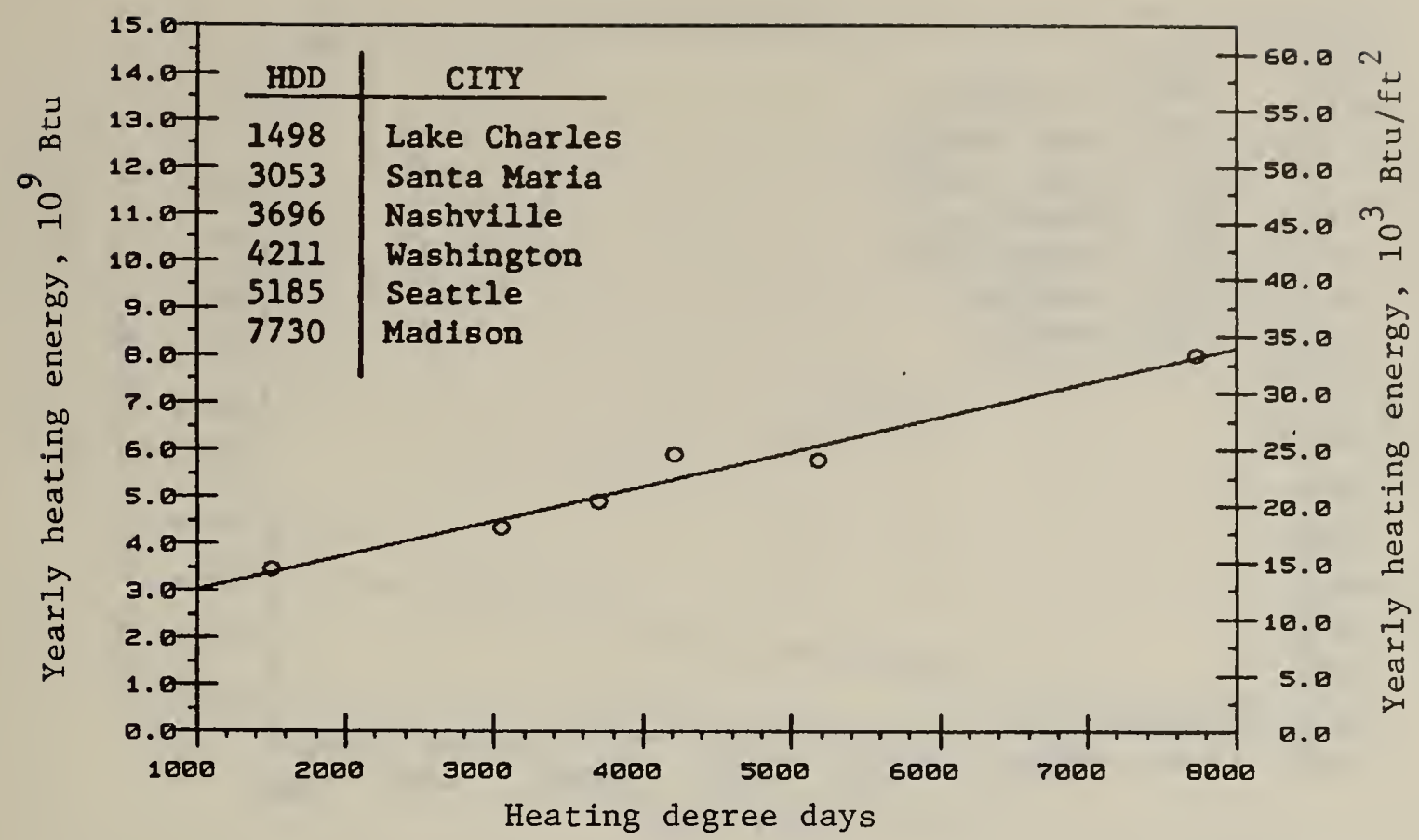

Figure 33. Heating energy consumption of case 7--base reheat with enthalpy economy cycle and supply air reset by zone load demand

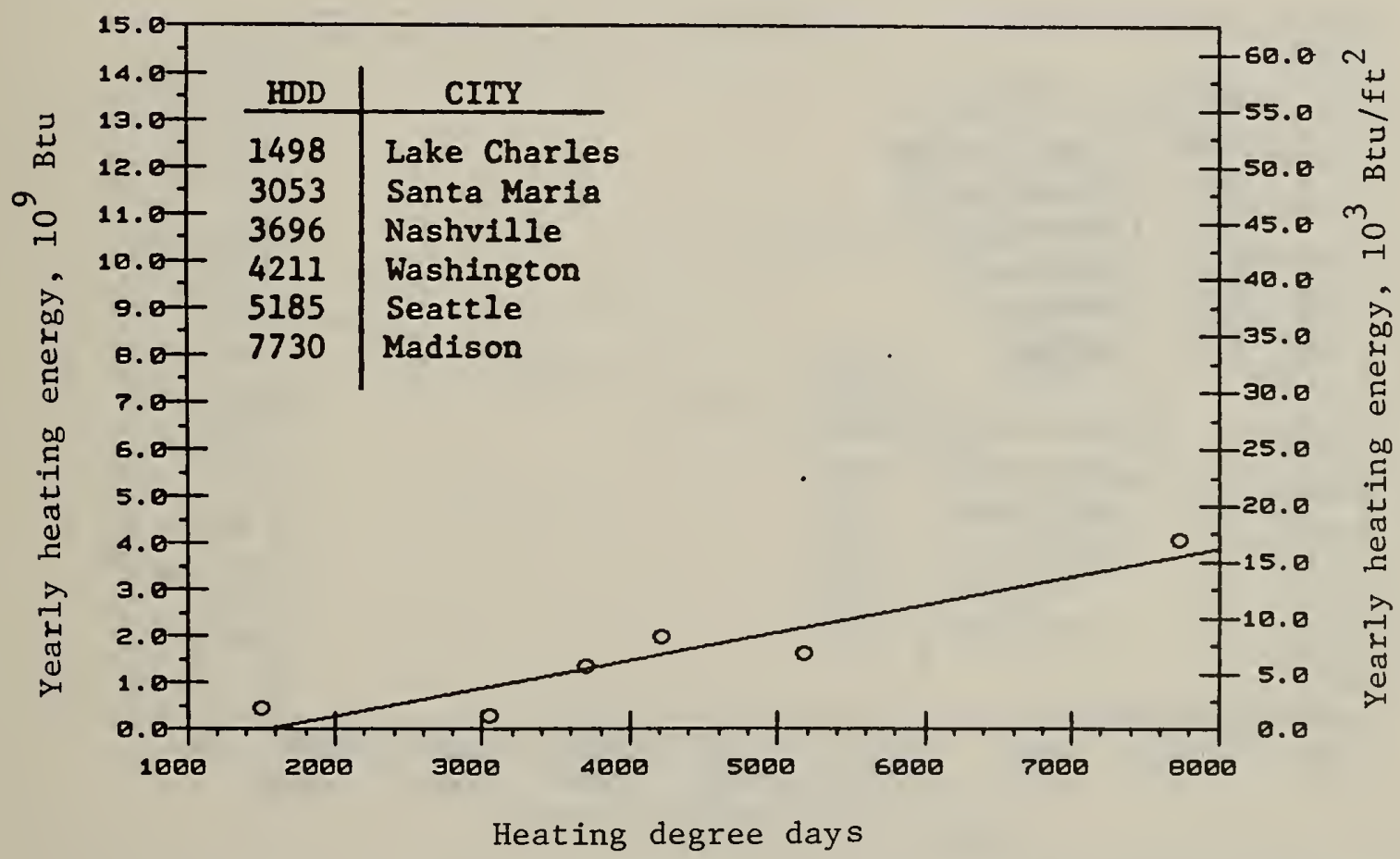

Figure 34. Heating energy consumption of case 8--base VAV 


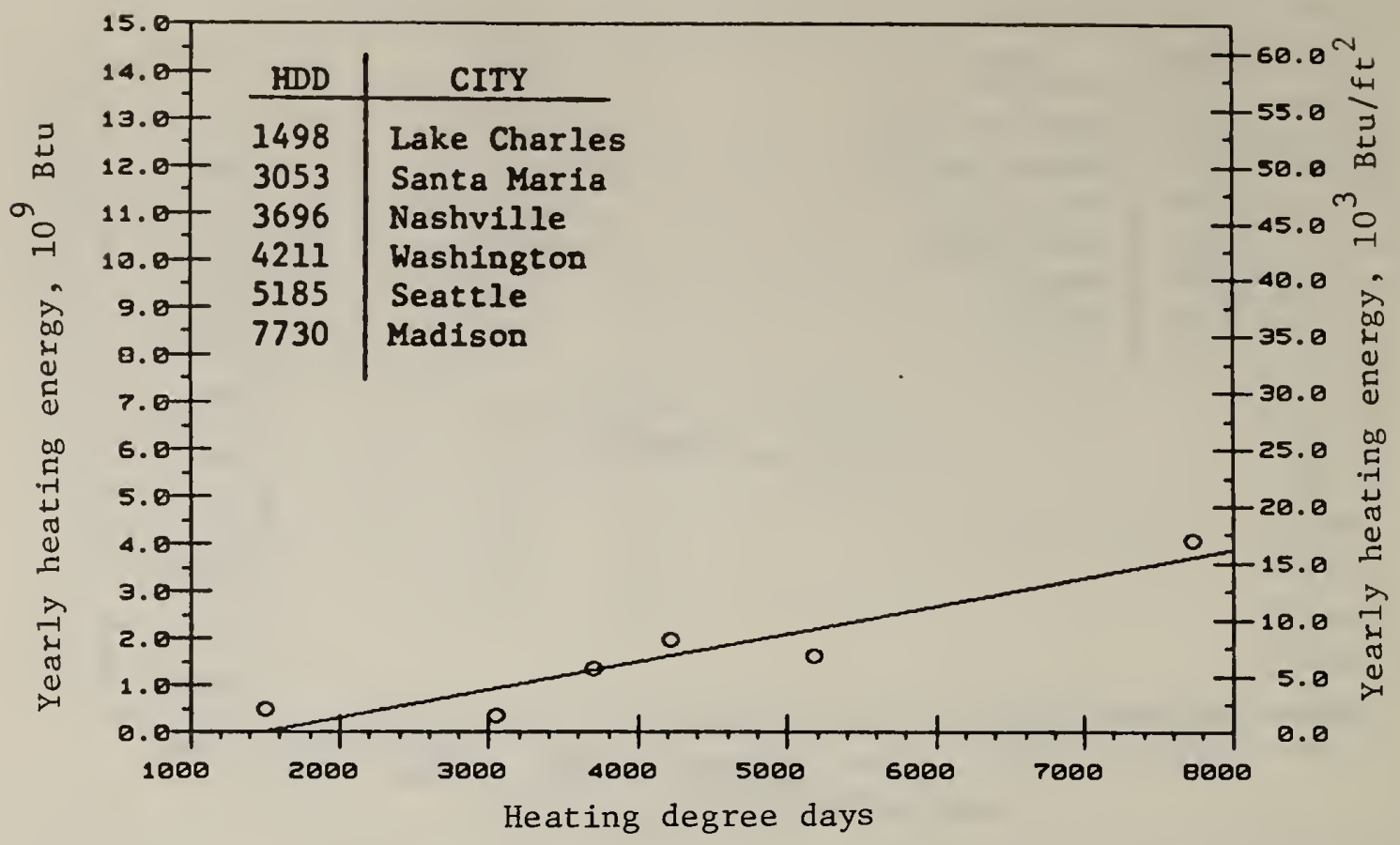

Figure 35. Heating energy consumption of case 9--base VAV with enthalpy economy cycle

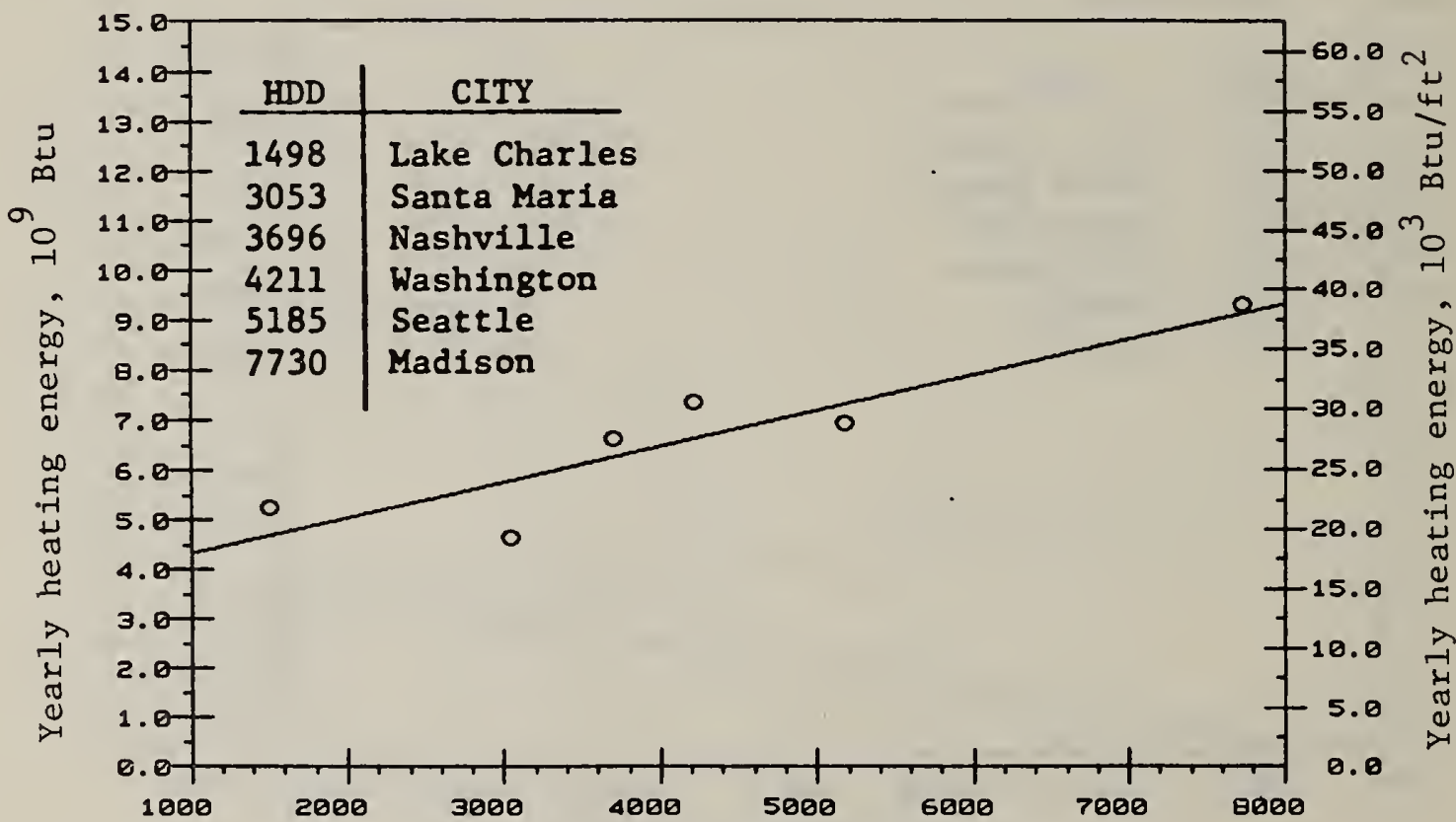

Heating degree days

Figure 36. Heating energy consumption of case 10--base $\mathrm{RH}$ for interior zones, base DD for perimeter zones 


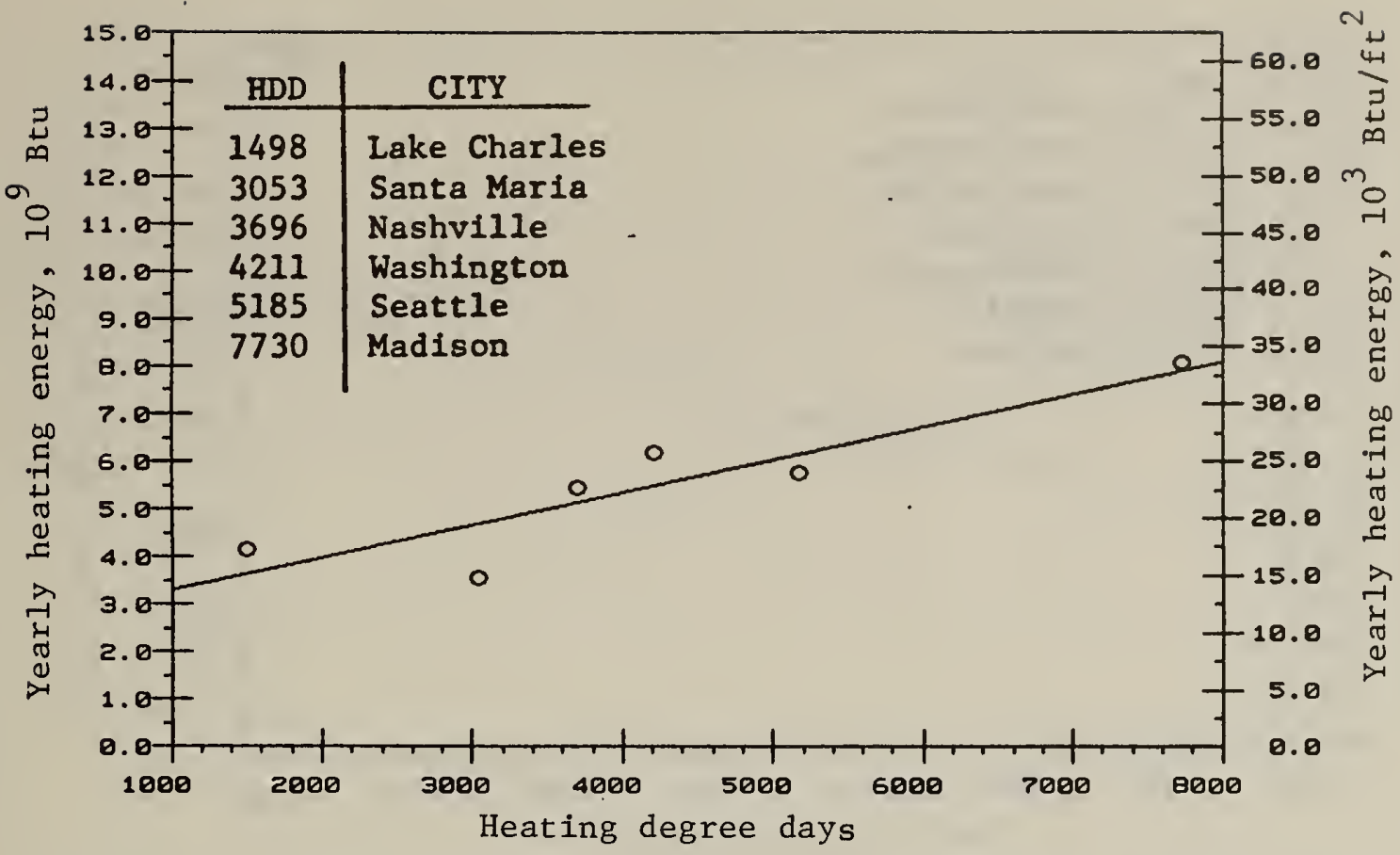

Figure 37. Heating energy consumption of case 11--base VAV for interior zones, base DD for perimeter zones

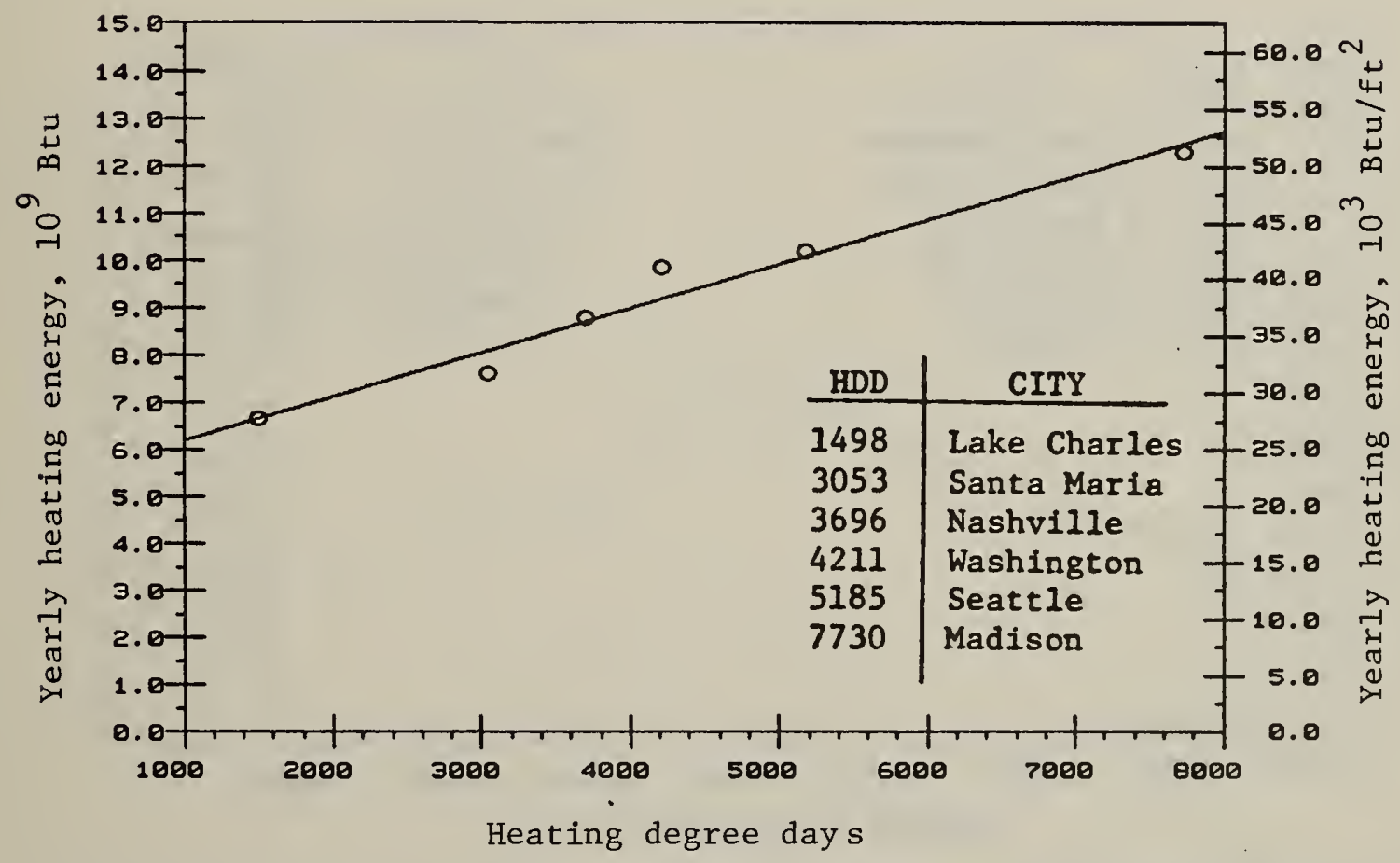

Figure 38. Heating energy consumption of case 12--base RH with enthalpy economy cycle for interior zones, base DD with enthalpy economy cycle for perimeter zones 


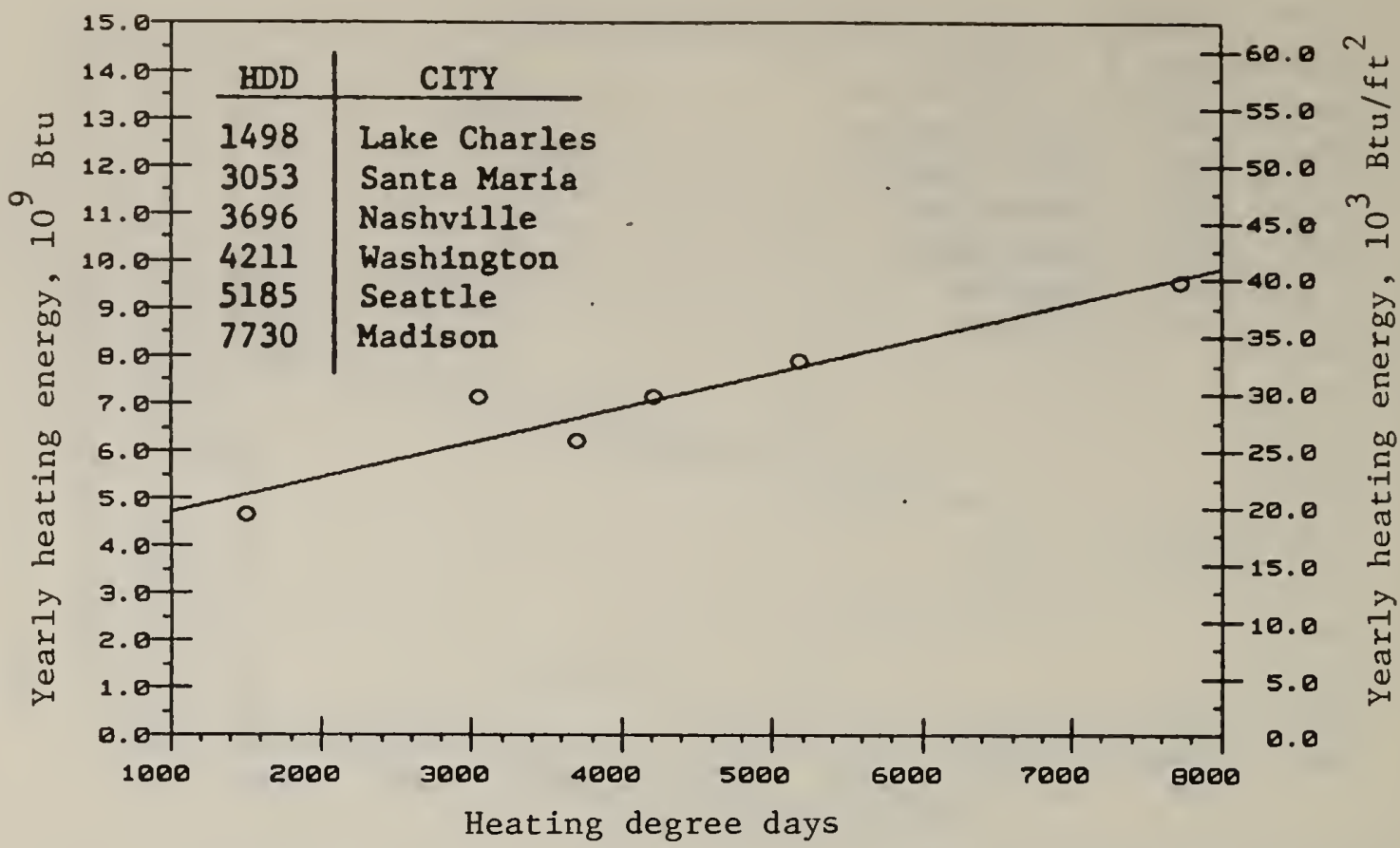

Figure 39. Heating energy consumption of case 13--base VAV with enthalpy economy cycle for interior zones, base DD with enthalpy economy cycle and hot deck reset by outside air for perimeter zones

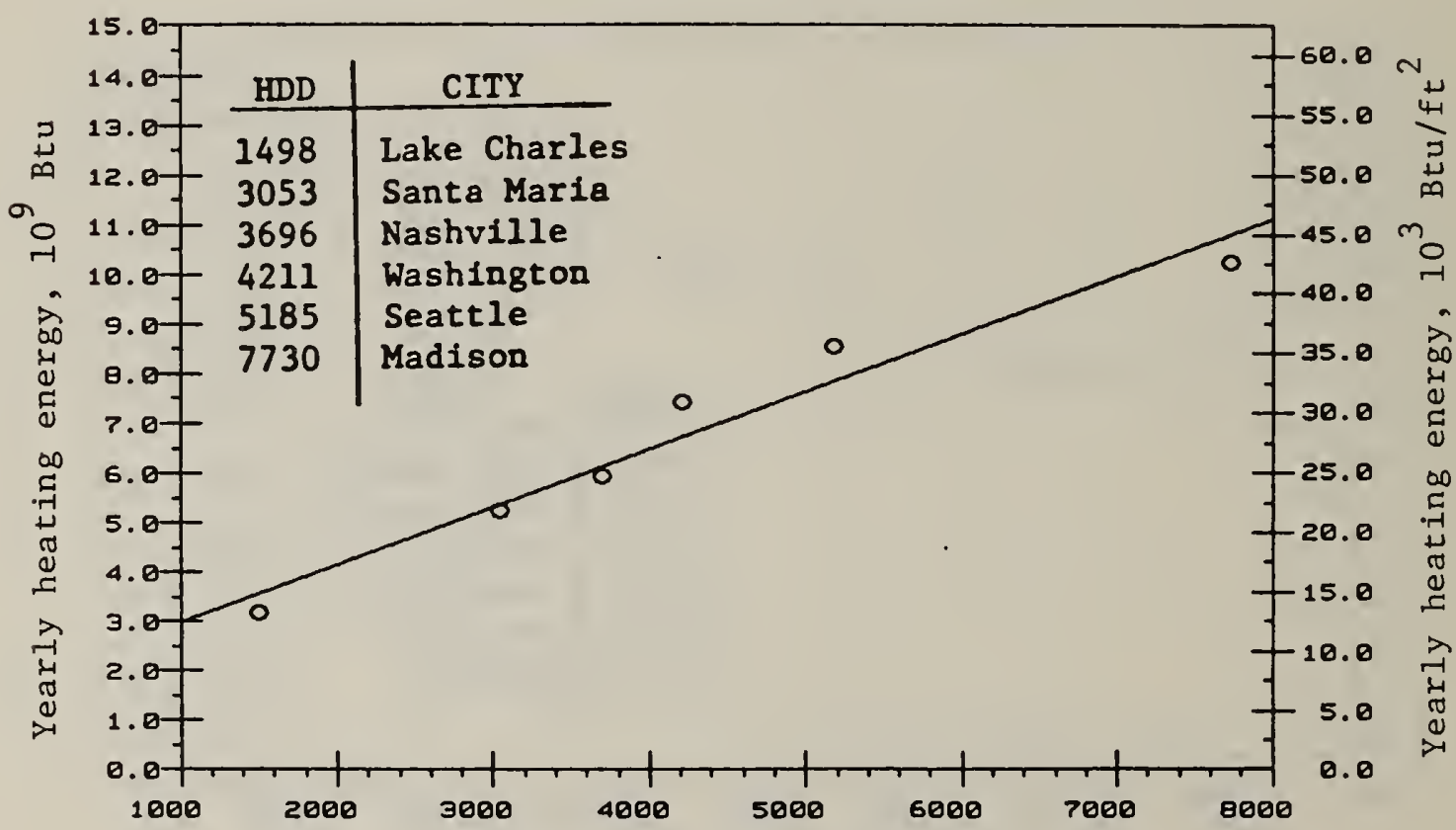

Heating degree days

Figure 40. Heating energy consumption of case 14--base RH with enthalpy economy cycle for interior zones, base DD with enthalpy economy cycle and hot deck reset by outside air for perimeter zones 


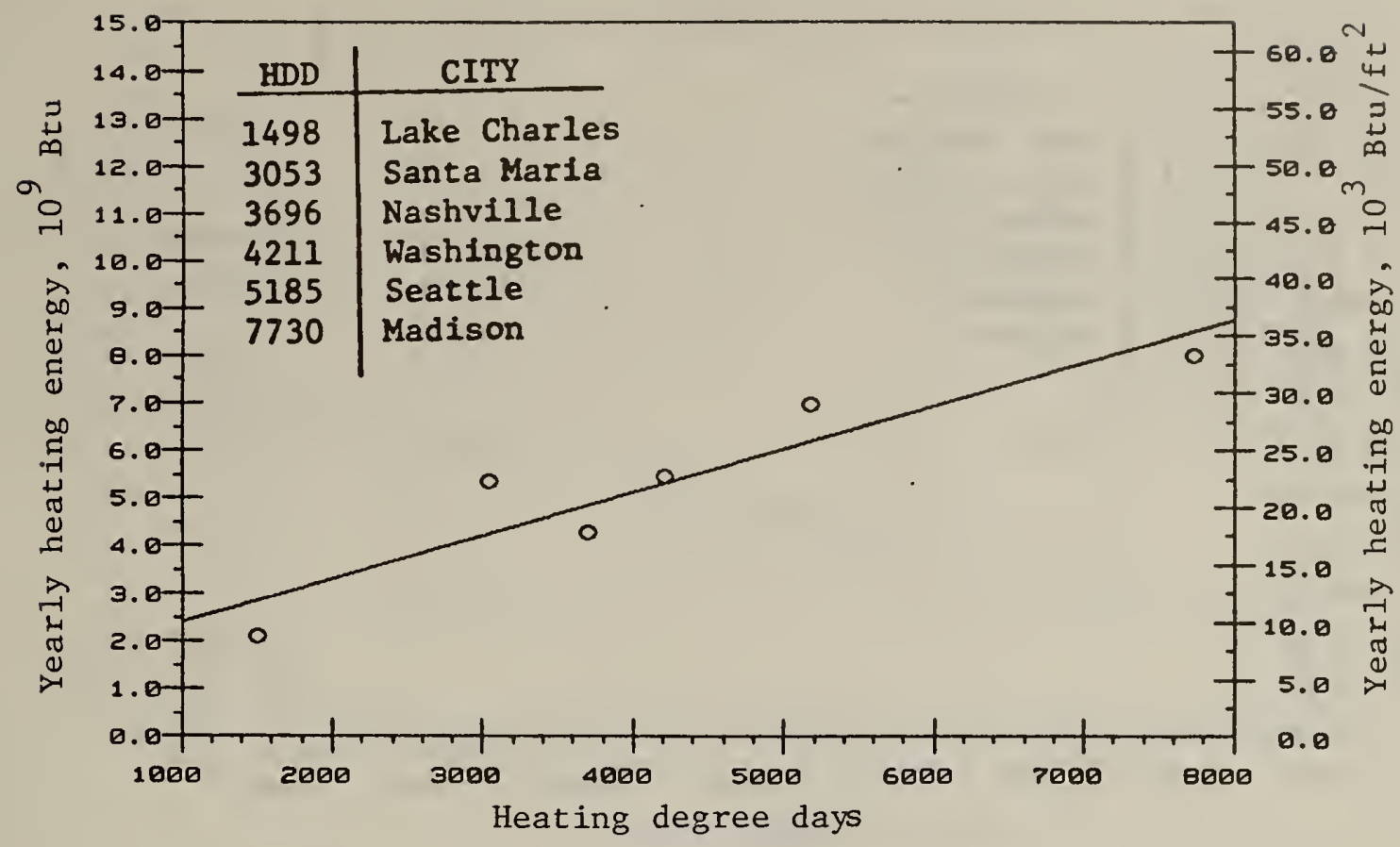

Figure 41. Heating energy consumption of case 15--base VAV with enthalpy economy cycle for interior zones, base DD with enthalpy economy cycle and hot deck reset by outside air for perimeter zones

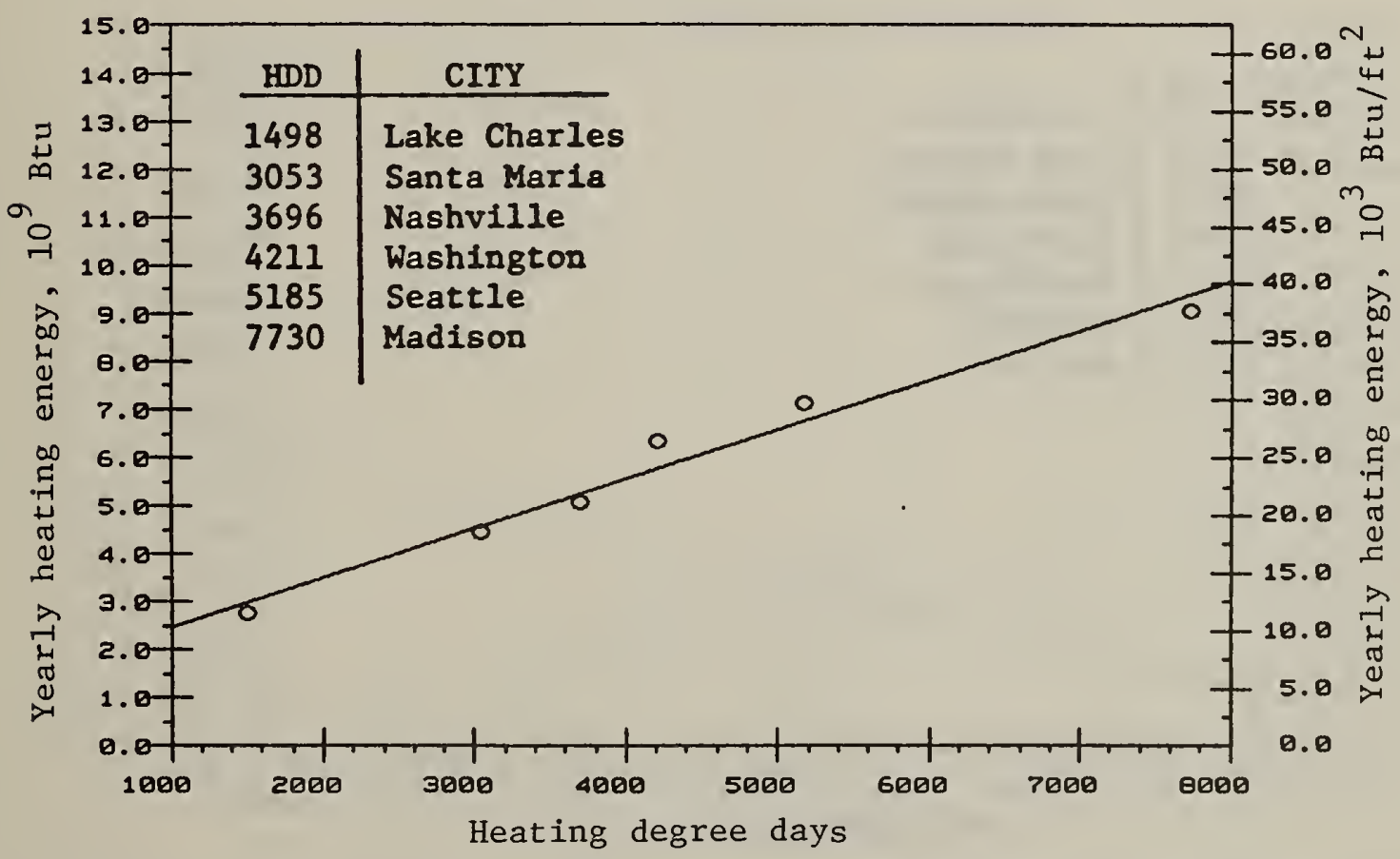

Figure 42. Heating energy consumption of case 16--base RH with enthalpy economy cycle and supply air reset by zone demand for interior zones, base DD with enthalpy economy cycle and hot - cold decks reset by zone demands for perimeter zones 


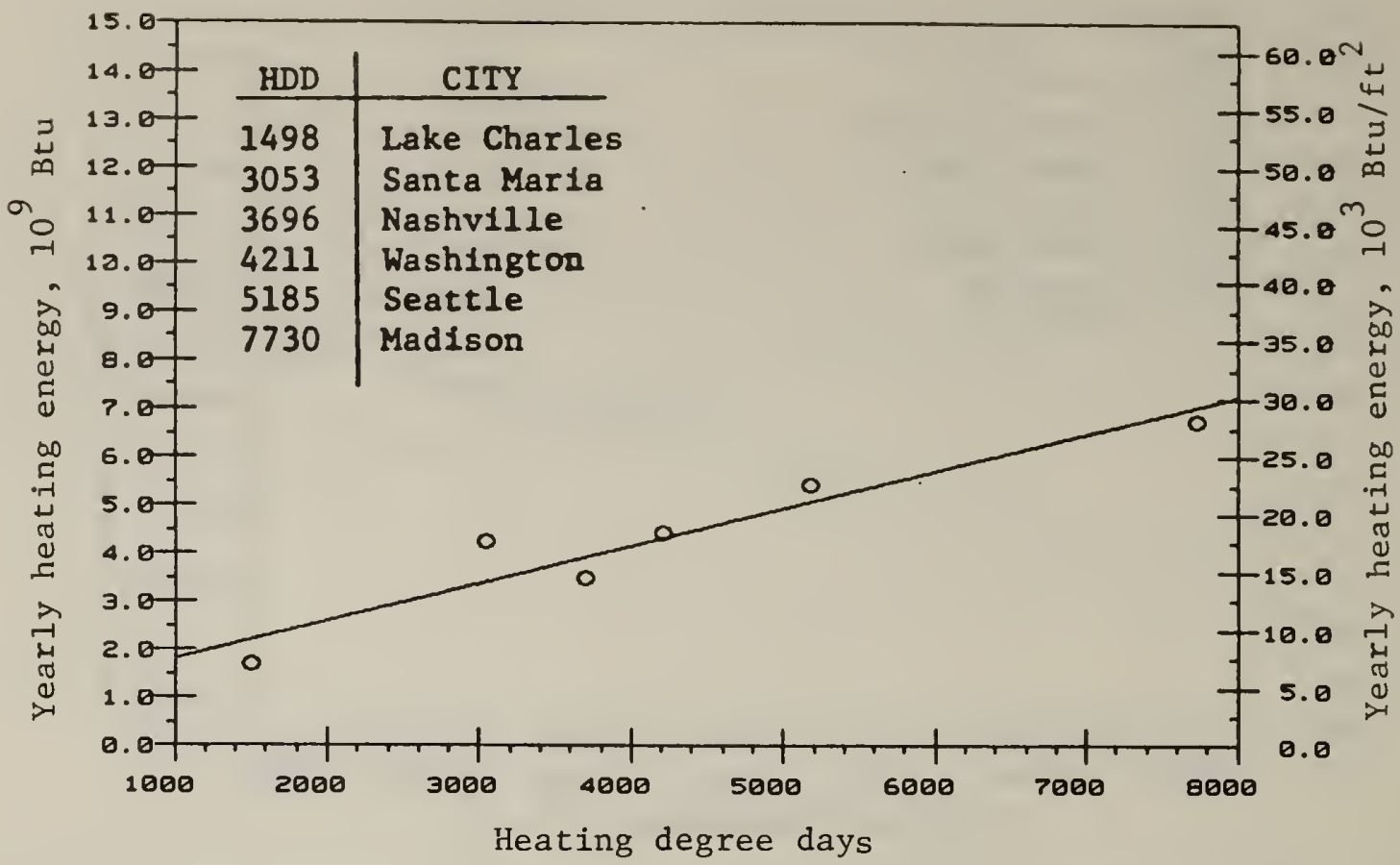

Figure 43. Heating energy consumption of case 17--base VAV with enthalpy economy cycle for interior zones, base $\mathrm{DD}$ with enthalpy economy cycle and hot-cold decks reset by zone demands for perimeter zones

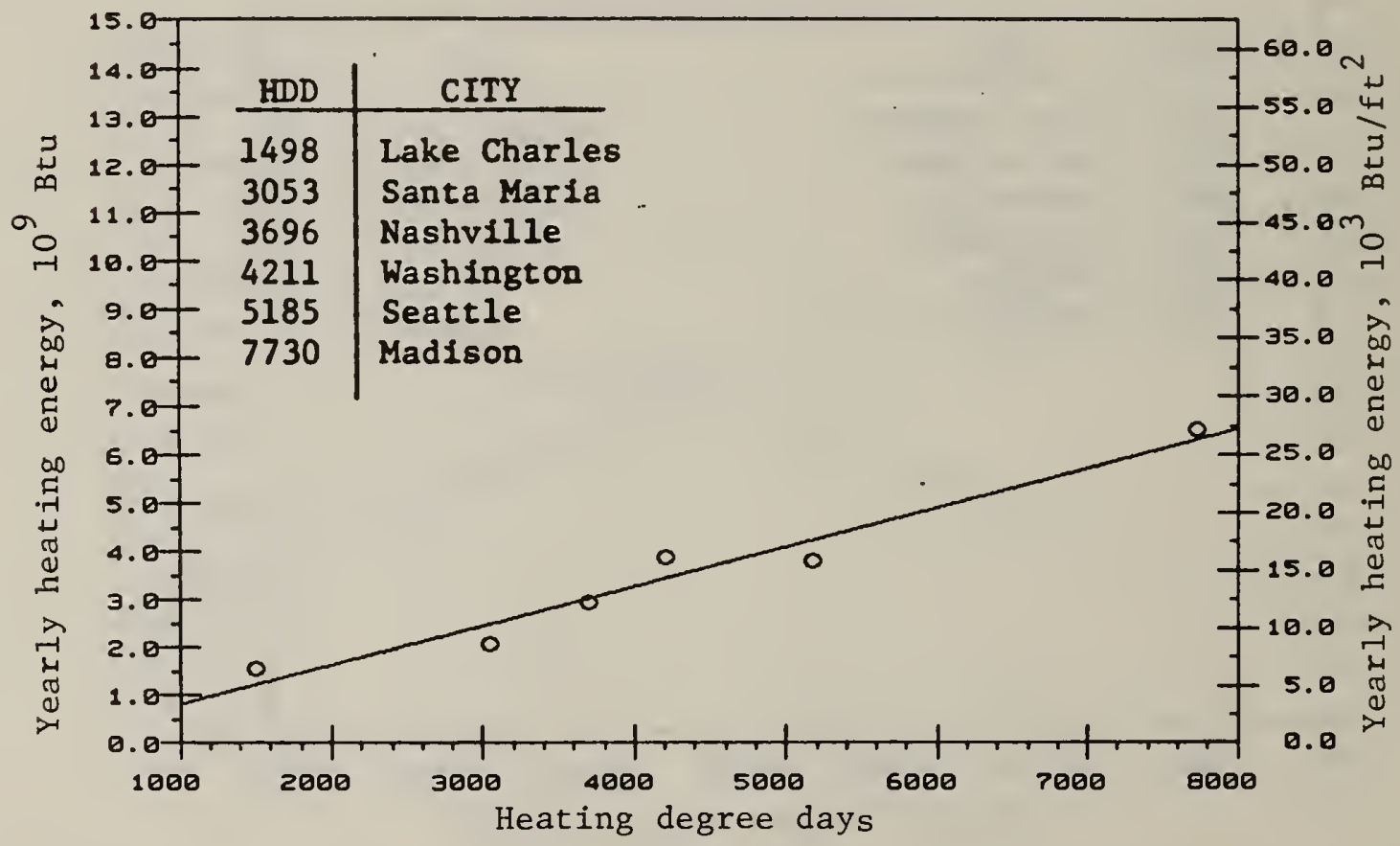

Figure 44. Heating energy consumption of case 18--base RH with enthalpy economy cycle and supply air reset by zone demand for interior zones, base VAV with enthalpy economy cycle for perimeter zones 


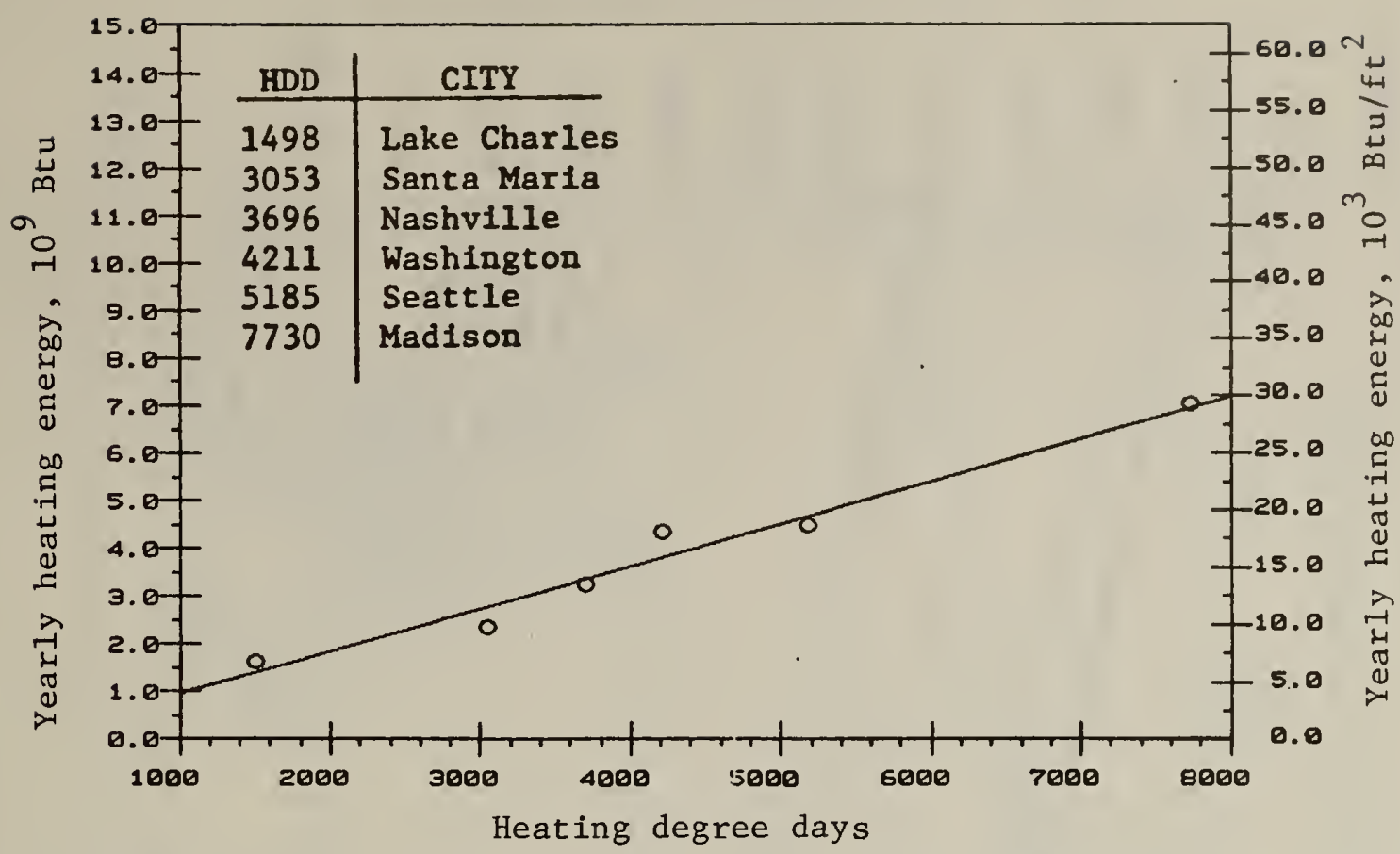

Figure 45. Heating energy consumption of case 19--base RH with enthalpy economy cycle and supply air reset by zone demand for interior zones, fan-coil for perimeter zones

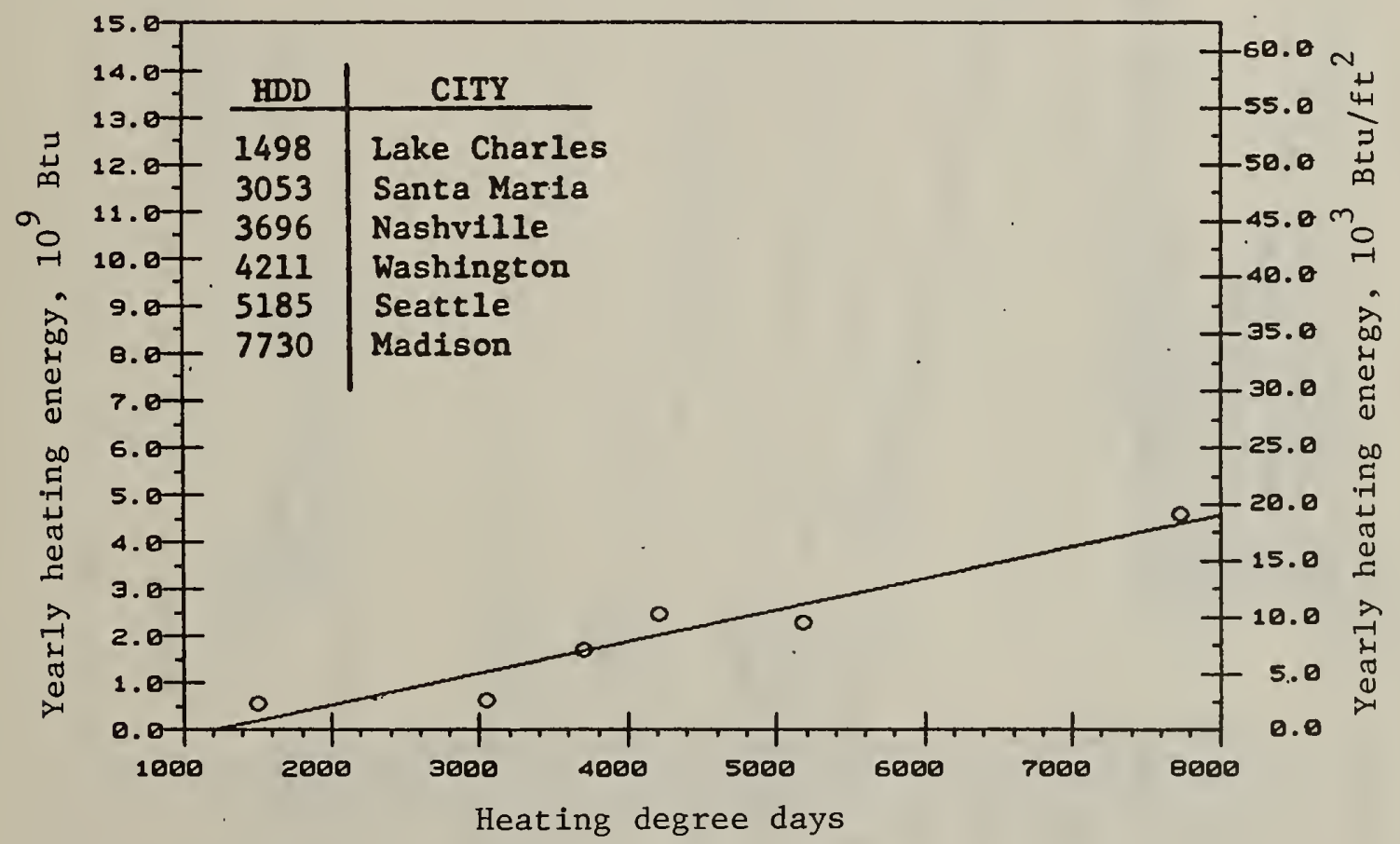

Figure 46. Heating energy consumption of case 20--base VAV with enthalpy economy cycle for interior zones, fan-coil for perimeter zones 


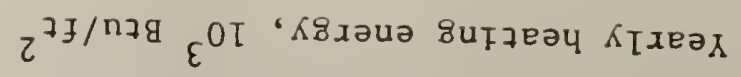






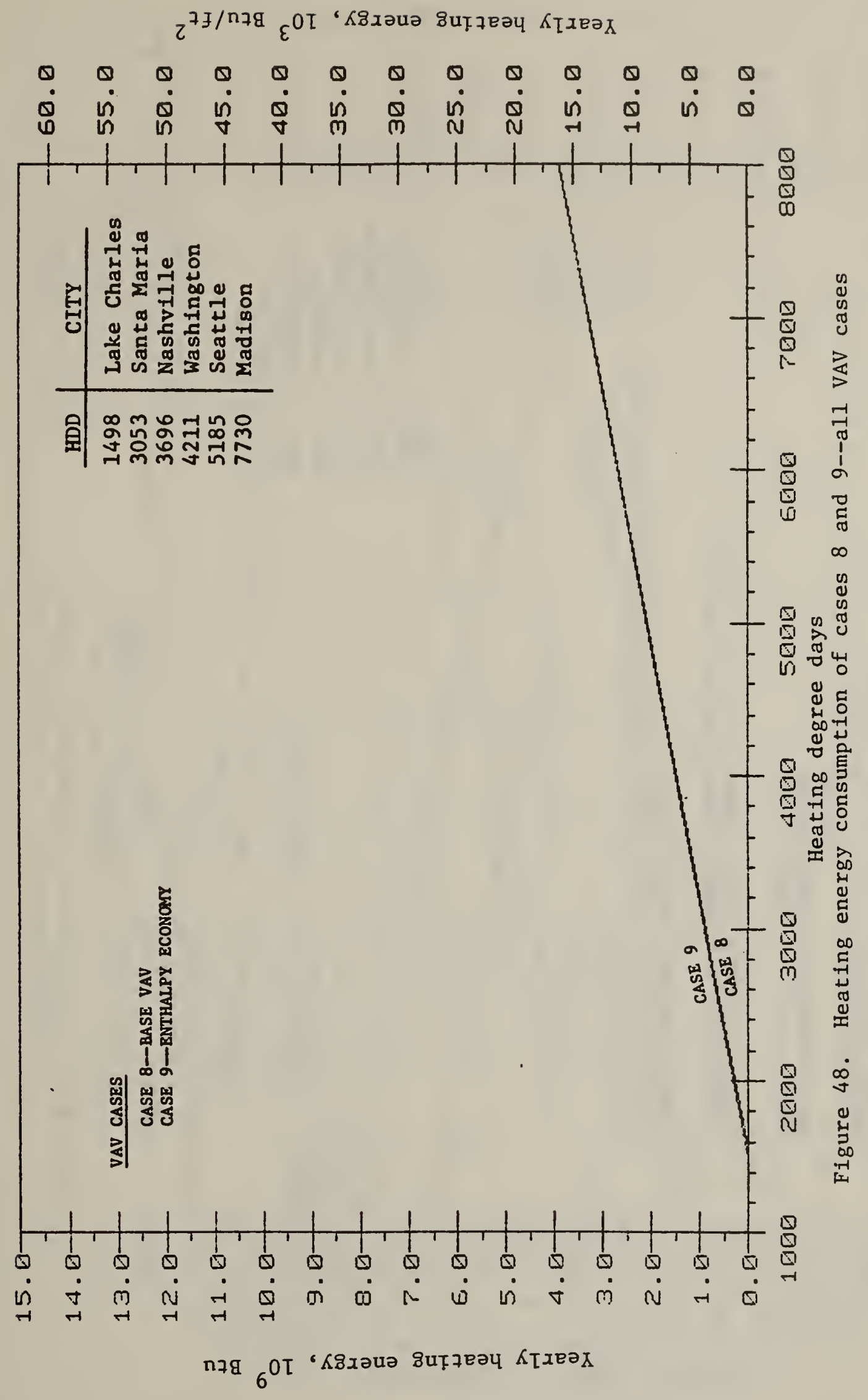




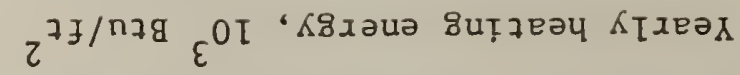

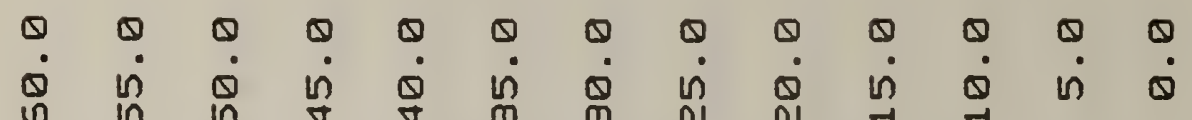

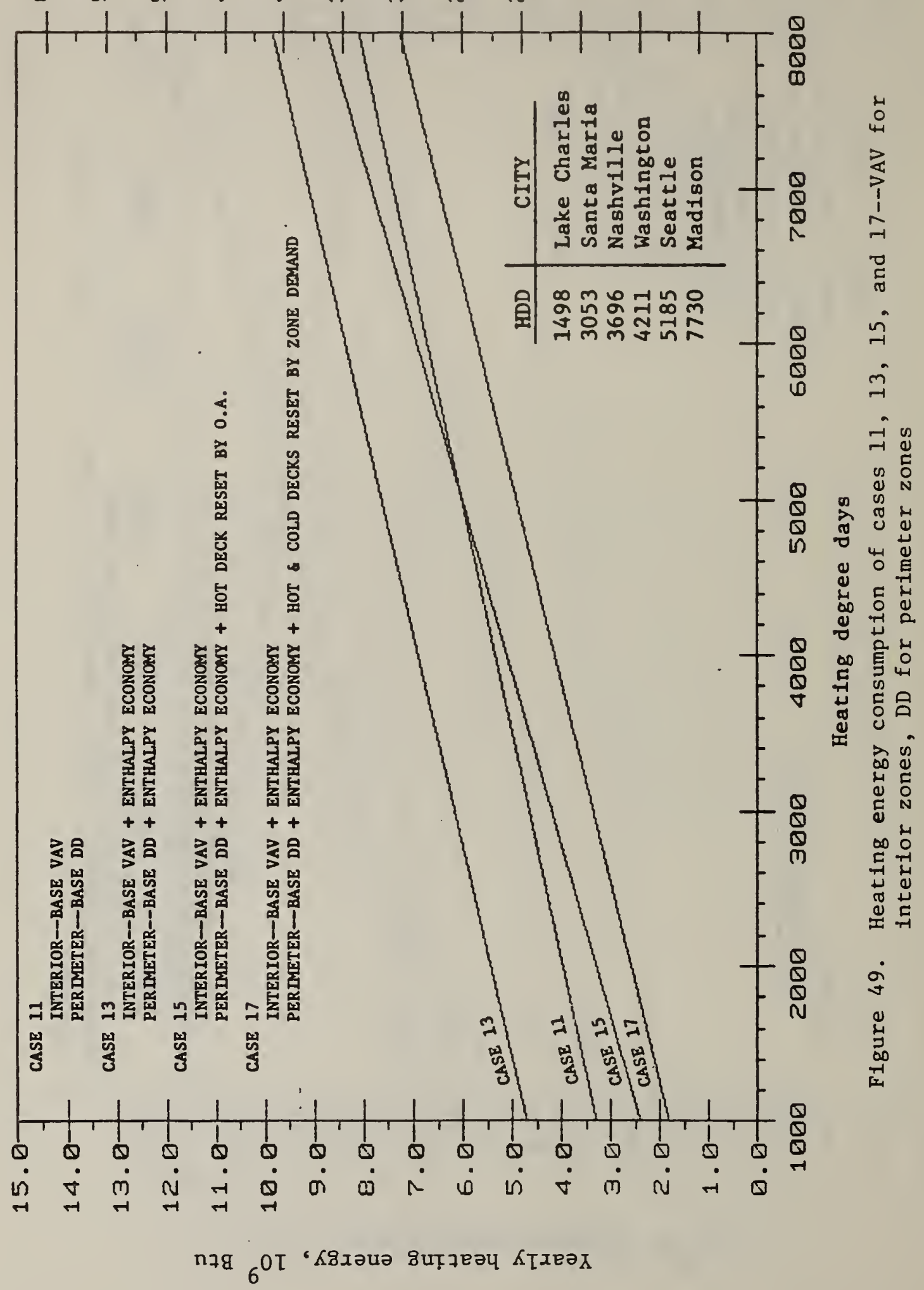




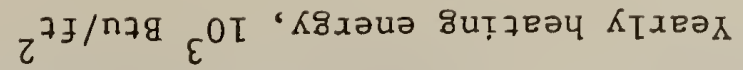

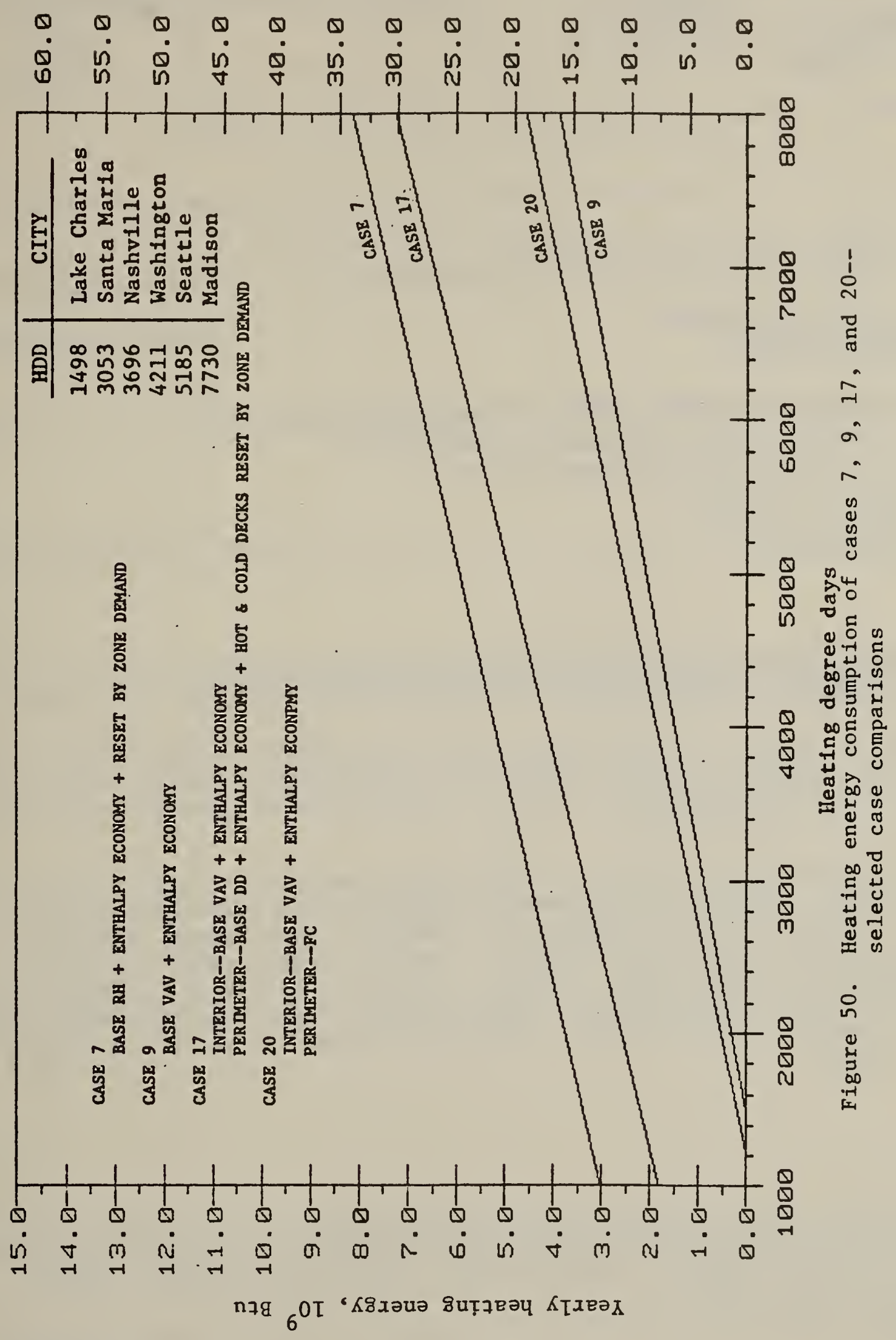


NBS.IIAA IREV. $2-8 \mathrm{C}$ \}

U.S. DEPT. OF COMM.

BIBLIOGRAPHIC DATA

SHEET (See in seructions)

1. PUBLICATION OR

REPORT NO.

NBSIR $83-2746$

2. Performing Organ. Report Nof 3. Publication Date

July 1983

4. TITLE AND SUBTITLE

Strategies for Energy Conservation for a Large Office Building

5. $A U T H O R(S)$

James Y. Kao

6. PERFORMING ORGANIZATION (If joint or other than NBS, see instructions)

7. Contract/Grant No.

NATIONAL BUREAU OF STANDARDS

DEPARTMENT OF COMMERCE

8. Type of Report \& Period Covered

WASHINGTON, D.C. 20234

9. SPONSORING ORGANIZATION NAME AND COMPLETE ADDRESS (Street, City, State, ZIP)

Office of Building Energy Research and Development

Office of Conservation and Renewable Energy

U.S. Department of Energy

Washington, DC 20585

10. SUPPLEMENTARY NOTES

[Document describes a computer program; SF-185, FIPS Software Summary, is attached.

11. ABSTRACT (A 200-word or less foctual summary of most significant information. If document includes a significant bibliogrophy or literoture survey. mention it here)

A comparative analysis is made of the thermal performance of selected HVAC systems and control strategies commonly employed in large office buildings. The comparisons are made for six geographical locations representing wide climatic variations within the continental United States.

Hour-by-hour simulations with the BLAST computer program are used to obtain the yearly heating, cooling, and fan energy consumption of a twelve-story large office building. The HVAC systems simulated are constant volume reheat, variable air volume, dual-duct, and fan-coil systems. The control strategies tested are dry bulb temperature economy cycles, enthalpy economy cycle, supply air temperature resetting, and the combinations of these strategies. The results of these simulations are presented and discussed. Substantial energy consumption differences are shown to exist.

12. KEY WORDS (Six to twelve entries; alphabetical order; capitalize only proper nomes; ond separate key words by semicolons) building control strategies; building energy conservation; building thermal performance; HVAC systems

\section{AVAILABILITY}

[X] Unlimited

For Official Distribution. Do Not Release to NTIS

$\square$ Order From Superintendent of Documents, U.S. Government Printing Office, Washington, D.C. 20402.

[X] Order From National Technical Information Service (NTIS), Springfield, VA. 22161
14. NO. OF PRINTED PAGES

69

15. Price

$\$ 10.00$ 

